\author{
UNIVERSIDADE DE SÃO PAULO \\ FACULDADE DE ECONOMIA, ADMINISTRAÇÃO E CONTABILIDADE \\ DEPARTAMENTO DE ADMINISTRAÇÃO \\ PROGRAMA DE PÓS-GRADUAÇÃO EM ADMINISTRAÇÃO
}

\title{
A POLÍTICA DE HEDGE PARA O CONTROLE DE RISCO NAS INSTITUIÇÕES NÃO-FINANCEIRAS UTILIZANDO OPÇÕES DE COMPRA
}

Márcio Jolhben Wu

Orientador: Prof. Dr. José Roberto Securato

SÃO PAULO 
Profa. Dra. Suely Vilela

Reitora da Universidade de São Paulo

Profa. Dra. Maria Teresa Leme Fleury

Diretora da Faculdade de Economia, Administração e Contabilidade

Prof. Dr. Isak Kruglianskas

Chefe do Departamento de Administração

Prof. Dr. Lindolfo Galvão de Albuquerque

Coordenador do Programa de Pós-Graduação em Administração 


\section{MÁRCIO JOLHBEN WU}

\section{A POLÍTICA DE HEDGE PARA O CONTROLE DE RISCO NAS INSTITUIÇÕES NÃO-FINANCEIRAS UTILIZANDO OPÇÕES DE COMPRA}

Dissertação apresentada ao Departamento de Administração da Faculdade de Economia, Administração e Contabilidade da Universidade de São Paulo como requisito para a obtenção do título de Mestre em Administração.

Orientador: Prof. Dr. José Roberto Securato 


\section{FICHA CATALOGRÁFICA}

\section{Elaborada pela Seção de Processamento Técnico do SBD/FEA/USP}

Wu, Márcio Jolhben

A política de hedge para o controle de risco nas instituições não-financeiras utilizando opções de compra / Márcio Jolhben Wu.

-- São Paulo, 2006.

123 p.

Dissertação (Mestrado) - Universidade de São Paulo, 2006

Bibliografia

1. Finanças das empresas 2. Risco (Proteção) 3. Opções financeiras I. Universidade de São Paulo. Faculdade de Economia, Administração e Contabilidade. II. Título.

CDD -658.15 
Para

Meus pais,

Meus irmãos,

E meu amor 
Agradeço ao professor José Roberto Securato, pelo apoio, pela amizade e encorajamentos contínuos na elaboração e conclusão da pesquisa, às dicas valiosas dos professores da banca: professor André Luiz Oda e professor Edson Ferreira de Oliveira ao professor Gustavo Cerbasi pelo valioso apoio e aos demais Mestres da casa, pelos conhecimentos transmitidos, e à FEA USP, pelo apoio institucional e pelas facilidades oferecidas. 
"Portanto, devemos considerar o estado atual do universo como efeito do seu estado anterior e como causa do estado que a ele sobrevirá. Uma inteligência que conseguisse conhecer, num dado momento, todas as forças que animam a natureza, bem como todas as posições ocupadas pelo seres que a constituem, e cujo raciocínio fosse suficientemente amplo para submeter todos estes três fatores a uma análise, esta inteligência poderia abranger, mediante uma única equação, tanto o movimento dos maiores corpos do universo, quanto o dos mais leves átomos. Para ela, nada seria duvidoso; o passado e futuro estariam diante de seus olhos com igual nitidez. Através da perfeição que soube dar à astronomia, o espírito humano revela débeis esforços de tal inteligência ...

Todos os seus esforços na busca da verdade aproximam-no dessa inteligência."

LAPLACE 


\section{RESUMO}

A estrutura de operações de defesa de posições de risco de uma instituição - banco e empresa, em geral chamada de hedge, é um dos problemas mais importantes da gestão financeira em um mundo em que as mudanças ocorrem com freqüência cada vez maior. Essa característica de volatilidade leva o gestor a elaborar a estrutura de hedge. Ocorre que se fizer o hedge de todas as posições de risco, invariavelmente, a despesa dessa defesa torna-se insuportável, praticamente consumindo o lucro da operação. Isso se torna mais critico para as instituições não-financeiras já que o seu principal negócio não se alicerça no gerenciamento de riscos, atividade mais própria para as instituições financeiras, mas sim na produção de serviços ou de produtos. Assim, políticas de hedge, instrumentos e modelos, que permitam indicar formas de gerenciamento de risco, tornam-se de grande importância. O presente trabalho tem essa preocupação e apresenta um modelo quantitativo que possibilitará à empresa determinar a melhor opção de compra para ser utilizada na sua política de hedge e, conseqüentemente, estabelecer a fração ótima da sua posição em risco que deverá ser protegida mediante duas condições: a primeira uma limitação orçamentária que a empresa possua para a operação de hedge; e a segunda, um valor pré-fixado do ativo objeto, a um dado nível de confiança, na data de vencimento da opção. A solução ótima obtida pelo modelo será uma função da distribuição de probabilidade do ativo (retorno e risco), taxa livre de risco, o horizonte do hedge e o nível de confiança desejado pela instituição. Para testar o modelo, utilizou-se o hedge com opções de compra sobre dólar disponível, que é um dos principais instrumentos de hedge oferecidos pela BM\&F. Uma janela de um mês foi escolhida para estudar a otimalidade da solução apontada pelo modelo. 


\begin{abstract}
The operations structure of defense of positions on risk of an institution - bank and company, in general, called hedge, is one of the most important problems of financial administration in a world where changes happen more frequently. This volatility characteristic leads the manager to elaborate the hedge structure. It happens that if he/she does the hedge of all of the risk positions, invariably, the expense of that defense becomes unbearable, practically consuming the whole profit of the operation. It becomes more critical in non-financial institutions since its main business is not related to the administration of risks, activity typical of financial institutions, but to the production of services or products. That is the reason why hedge politics, instruments and models, that allow indicating forms of risk administration, become of great importance. The present work brings that concern and develops a quantitative model that it will make possible to the company to determine the best call option to be used in its hedge politics and, consequently, to establish the great fraction of its position in risk that should be protected by two conditions: the first one, a budget limitation that the company possesses for the hedge operation; and second one, a pre-set value of the asset object, to a trust level, in the date of expiration of the option. The optimal solution obtained by the model will be a function of the distribution of probability of the assets (return and risk), risk free rate, the horizon of the hedge and the trust level set by the institution. To test the model, the hedge was used with purchase options on available dollar that it is one of the main hedge instruments offered by BM\&F. A window of one month was chosen to study the optimal solution pointed for the model.
\end{abstract}




\section{SUMÁRIO}

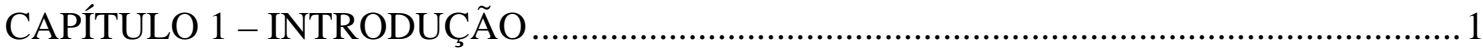

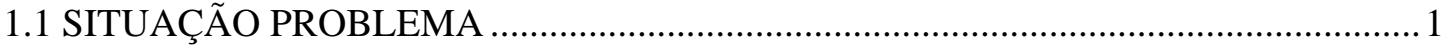

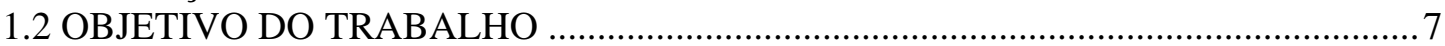

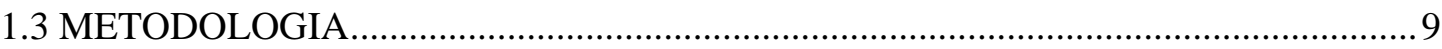

1.4 DESCRIÇÃO DOS CAPÍTULOS ……………………………………………....11

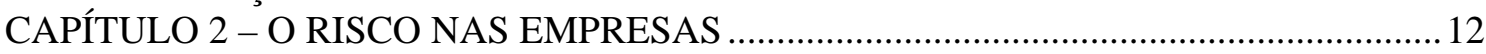

2.1 DEFINIÇÃO DE RISCO ……………………………………………….....12

2.2 TIPOS DE RISCOS .........................................................................................

2.2.1 Risco Sistêmico e Não Sistêmico ………………………………………………....15

2.2.2 Outras Classificações de Risco .............................................................................16

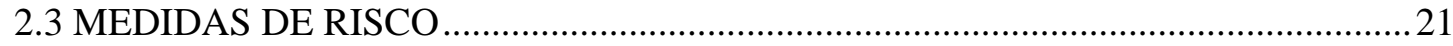

2.4 O RISCO NAS INSTITUIÇÕES FINANCEIRAS ………………………………….......

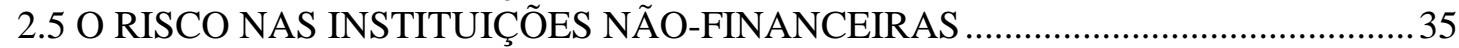

CAPÍTULO 3 - O HEDGE NAS EMPRESAS ……………............................................

3.1 A EMPRESA E O SEU NEGÓCIO ...........................................................................38

3.2 O CONCEITO DE HEDGE ............................................................................

3.3 O HEDGE E O VALOR DA EMPRESA ………………….................................4

3.4 ARGUMENTOS DE QUE O HEDGE NÃO CRIA VALOR PARA A EMPRESA ....45

3.5 QUANDO O HEDGE CRIA VALOR PARA A EMPRESA E SOBRE O QUE FAZER

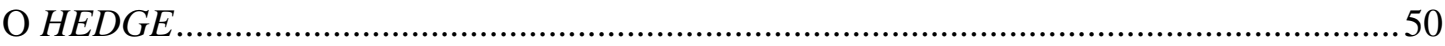

3.5.1 Quando o hedge cria valor para a empresa..............................................................50

3.5.2 Sobre o que fazer o hedge …………………………….....................................5

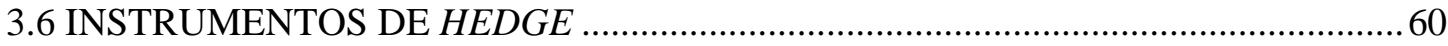

3.7 PRECIFICAÇÃO DE OPÇÕES.............................................................................64

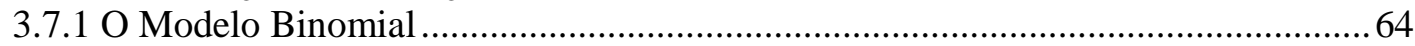

3.7.2 O Modelo de Black-Scholes (B\&S) ……………………………………….......66

CAPÍTULO 4 - A POLÍTICA DE HEDGE E OS NEGÓCIOS DA EMPRESA …………......72

4.1 ENTENDENDO A EMPRESA..........................................................................

4.2 A POLÍTICA DA GESTÃO DE RISCO ………………………………………........

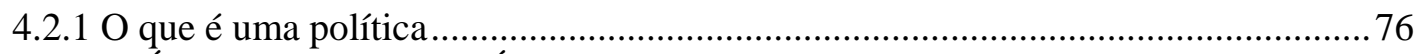

4.3 PRINCÍPIOS DE UMA POLÍTICA DE HEDGE.....................................................78

CAPÍTULO 5 - METODOLOGIA PARA ESTABELECIMENTO DE POLÍTICA DE HEDGE NAS EMPRESAS EM FUNÇÃO DO PREÇO DE EXERCÍCIO DA OPÇÃO DE COMPRA

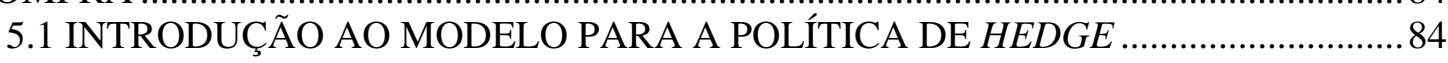

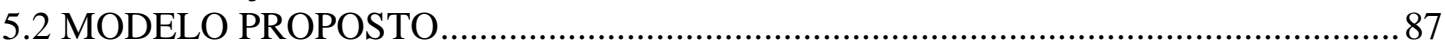

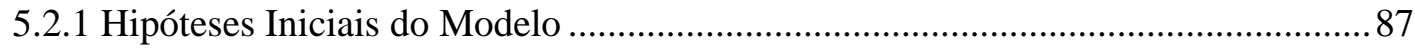

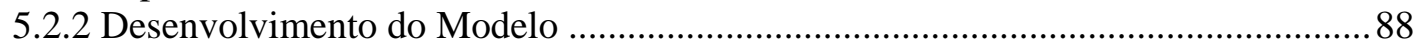

5.2.3 O Modelo para o hedge parcial adequado à política de hedge ...............................92

CAPÍTULO 6 - APLICANDO O MODELO PARA O HEDGE PARCIAL ADEQUADO À

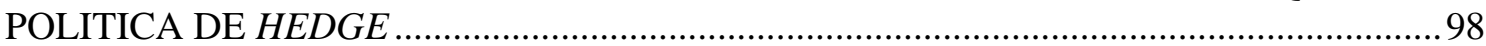

CAPÍTULO 7 - CONSIDERAÇÕES FINAIS ................................................................. 108

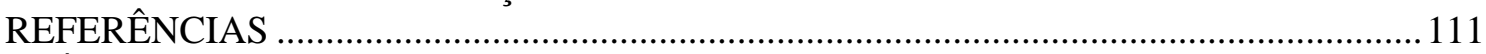

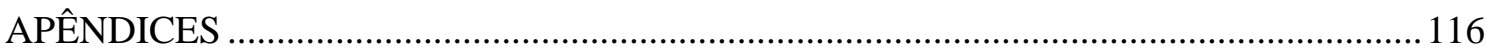

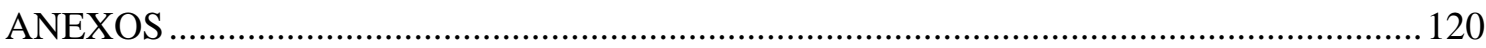




\section{LISTA DE ILUSTRAÇÕES}

Gráfico 1 - Resultado da operação com o hedge parcial em função de diversos $D_{T}$ 103

Gráfico 2 - Resultado do hedge parcial em função do preço de strike para um LO de R\$ 10/1.000US\$ 105

Gráfico 3 - Resultado da operação com o hedge parcial para diversos LOs 106

Gráfico 4 - Resultado da operação com o hedge parcial em função do preço de strike para diversos resultados fixados por R\$ / US\$ 1.000 107

Figura 1 - Taxas de câmbio marco alemão / dólar americano de final de mês ..........................2

Figura 2 - Evolução de produtos para gerenciamento de risco............................................ 4

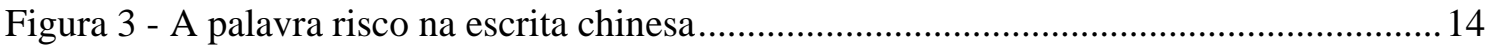

Figura 4 - Risco sistêmico e não sistêmico em relação ao mercado e à empresa.......................16

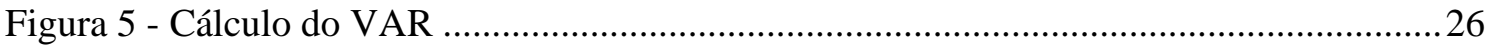

Figura 6 - A evolução das ferramentas de gerenciamento do risco .......................................... 31

Figura 7 - Abordagem do gerenciamento de risco para toda empresa ...................................35

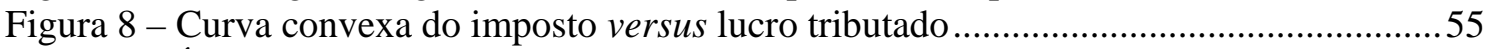

Figura 9 - Árvore binomial de dois estados para o ativo S..................................................64

Figura 10 - Árvore binomial de dois estados para a opção C...............................................64

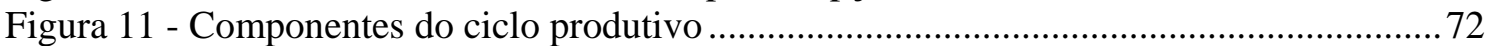

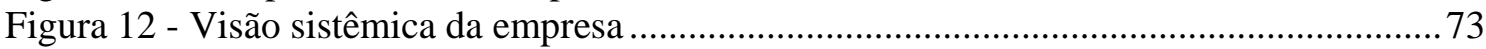

Figura 13 - Fixando $D_{T}$ a partir da sua distribuição de probabilidade ..................................97

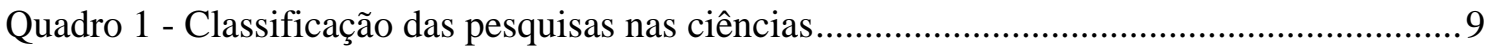

Quadro 2 - Principais diferenças entre opções e contratos futuros e a termo..........................63 


\section{LISTA DE TABELAS}

Tabela 1 - Variação na intensidade de uso de derivativos: 2003/2002 e 2002/2001.................6

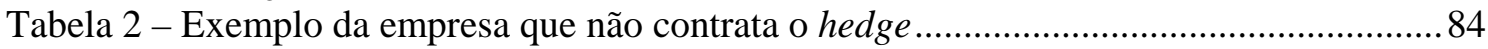

Tabela 3 - Exemplo de contratação de hedge com o exercício da call .....................................85

Tabela 4 - Exemplo de contratação de hedge sem o exercício da call .....................................86

Tabela 5 - Relação de opções de compra de dólar disponíveis na BM\&F em 03/06/2002 ...... 99

Tabela 6 - Resultado do hedge parcial em função dos contratos de dólar disponível .............104 


\section{LISTA DEABREVIATURAS E SIGLAS}

\begin{tabular}{|c|c|}
\hline BIS & Bank of International Settlements \\
\hline $\mathrm{BM} \& \mathrm{~F}$ & Bolsa de Mercadorias \& Futuros \\
\hline BOVESPA & Bolsa de Valores de São Paulo \\
\hline B\&S & Black \& Scholes \\
\hline CAPM & Capital Asset Pricing Model \\
\hline CVAR & Valor em Risco Condicional \\
\hline CFTC & Commodity Futures Trading Commission \\
\hline G30 & $\begin{array}{l}\text { Grupo Consultivo sobre Economia Internacional e } \\
\text { Questões Monetárias }\end{array}$ \\
\hline $\mathrm{LO}$ & Limite Orçamentário \\
\hline $\mathrm{M} \& \mathrm{M}$ & Modigliani \& Miller \\
\hline NBC & Nonbank Corporation \\
\hline PPP & Purchasing Power Parity \\
\hline SEC & Securities and Exchange Commission \\
\hline VAR & Valor em Risco \\
\hline
\end{tabular}




\section{CAPÍTULO 1 - INTRODUÇÃO}

\subsection{SITUAÇÃO PROBLEMA}

A década de 60 foi um período marcado por uma intensificação do livre comércio: liberdade do capital e estabilidade das moedas. O dólar, atrelado ao lastro ouro, contribuiu significativamente para esse cenário.

É a partir dessa década que a economia assume um aspecto mais transnacional. Segundo Hobsbawn (1995, p. 272:273), havia três aspectos principais nessa transnacionalização: as empresas multinacionais, a nova divisão internacional do trabalho e o aumento do financiamento externo. A nova divisão internacional do trabalho implicava a saída da produção industrial dos países desenvolvidos, para outros que oferecessem vantagens fiscais e produtivas, entre outras. O aumento do fluxo de capital externo (euromoeda ou eurodólares) provinha, principalmente, de depósitos feitos em bancos não americanos e de um crescente aumento de investimentos nos gastos políticos e militares dos EUA. Esse mercado subiu de 14 bilhões de dólares em 1964 para aproximadamente 160 bilhões de dólares em 1973 e quase 500 bilhões cinco anos depois. Esses fluxos de capital percorriam o globo de moeda em moeda; como conseqüência, houve perdas do controle das taxas de câmbio e do volume de recursos em circulação. Segundo Hobsbawn (1995, p. 279):

Economicamente, esse equilíbrio dependia de uma coordenação entre o crescimento da produção e os ganhos que mantinham os lucros estáveis. Um afrouxamento na ascensão contínua de produtividade e/ou um aumento desproporcional nos salários resultariam em desestabilização. Dependia do que estivera tão dramaticamente ausente no entreguerras, um equilíbrio entre o crescimento da produção e a capacidade dos consumidores de comprá-la. Os salários tinham de subir com rapidez suficiente para manter o mercado ativo, mas não para espremer os lucros. Como, porém, controlar salários numa era de demanda excepcionalmente florescente? Como, em outras palavras, controlar a inflação, ou pelo menos mantê-la dentro de limites? Por último, a Era de Ouro dependia do esmagador domínio político e econômico dos EUA, que atuavam - às vezes sem pretender - como um estabilizador e assegurador da economia mundial. 
Mas em 1971, com uma acelerada inflação, um aumento dos meios circulantes do mundo e um enorme déficit americano, devido principalmente à Guerra do Vietnã (1965-1973), dá-se, por fim, o principal instrumento de estabilização da economia pós-guerra: o acordo de Bretton Woods, que havia fixado o lastro-ouro em 1944.

O sistema mundial de câmbio tornou-se muito mais livre da noite para o dia, provocando fortes oscilações na paridade das moedas. Os maiores mercados de comércio exterior foram temporariamente fechados, fazendo com que as instituições financeiras arcassem com grandes prejuízos.

A figura seguinte retrata a mudança percentual no valor do marco alemão relativamente ao dólar americano. A mudança nos níveis de volatilidade é bastante significativa no início da década de 70.

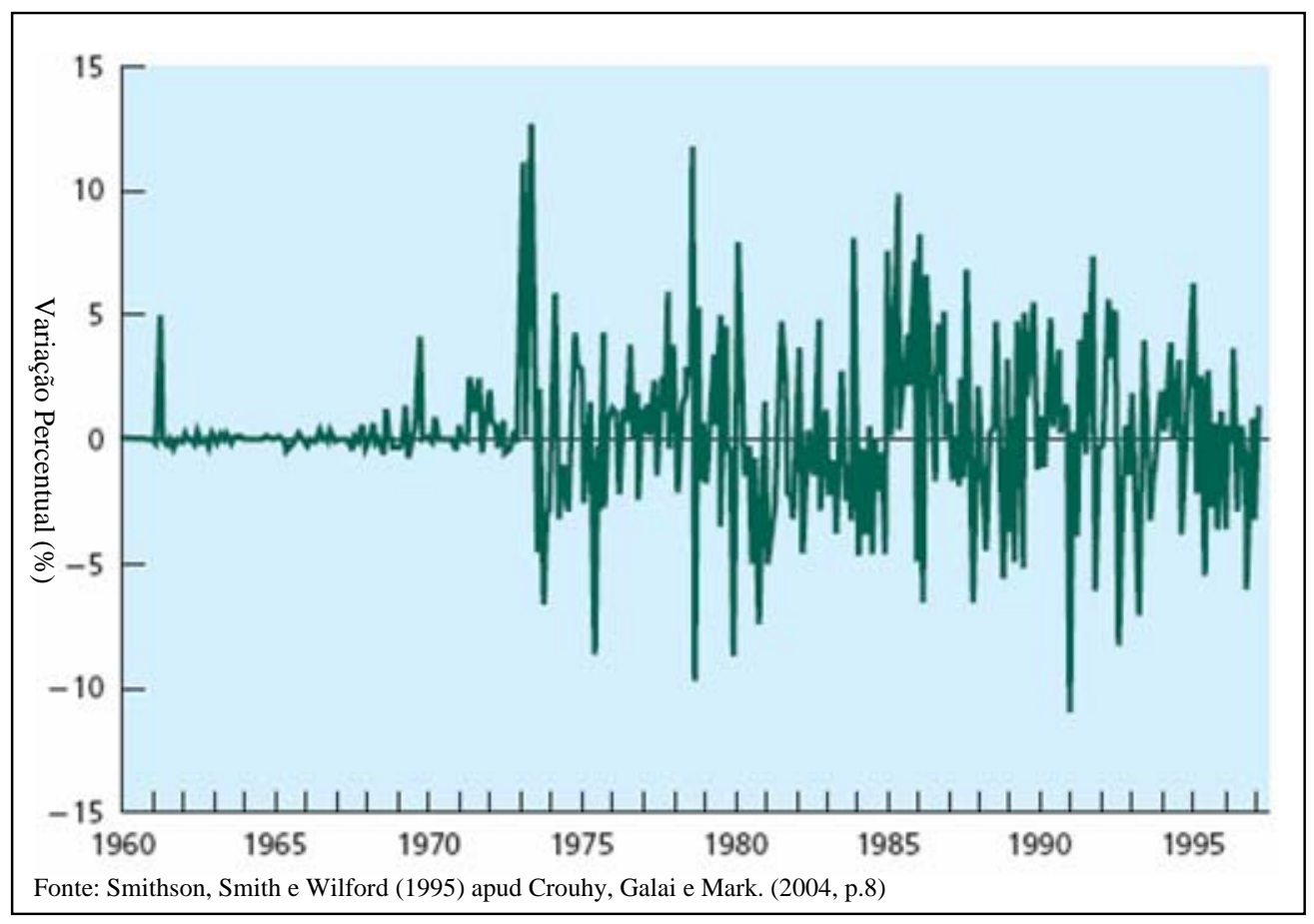

Figura 1 - Taxas de câmbio marco alemão / dólar americano de final de mês 
Segundo Kurtzman (1995, p. 68:69), o fim do padrão ouro colocou rivais do mesmo lado formando um dos maiores cartéis do mundo e fazendo com que, do início da década de 70 ao início de 80, o preço do barril de petróleo saltasse de U\$ 4 para U\$ 39, e o mundo presenciasse uma elevação geral de preços de aproximadamente $400 \%$.

Ainda segundo Kurtzman (1995, p. 70):

A economia financeira se tornou muito maior do que a economia real, a volatilidade se instalou. Taxas de juros, nível de preços, preços de ações e de títulos, preços de commodities, todos flutuavam terrivelmente com as taxas de câmbio.

Um novo tipo de cliente surgia nos mercados financeiros: a empresa que procurava transferir os riscos associados a essa volatilidade para alguém mais bem preparado para enfrentá-los. Assim, elas poderiam se concentrar no que fazem de melhor: administrar seu próprio negócio.

Os reflexos daquele período, intensificado pelo processo de internacionalização dos mercados mundiais e pelo barateamento da informação, fizeram com que o controle do risco ganhasse um maior destaque.

É nesse período que explodem as inovações do mercado financeiro.

Segundo Miller (1997, p. 4:5), haveria duas possíveis explicações para esse fenômeno. A primeira seria a convergência da mudança do regime cambial fixo para o flexível, aliado ao desenvolvimento da tecnologia, em especial os computadores acessíveis e confiáveis o suficiente para o desenvolvimento de novos produtos e no processamento das operações; a segunda seria que o boom das inovações foi meramente um atraso do desenvolvimento financeiro, prejudicado principalmente pela crise de 29 e pela Segunda Guerra Mundial. 
A figura seguinte retrata a evolução de instrumentos de gerência de risco ao longo de um período de vinte anos, a partir de 1972. Esses produtos são os derivativos. Alguns deles são negociados em Bolsa, mas a maioria é de produtos do mercado de balcão ou interbancários.

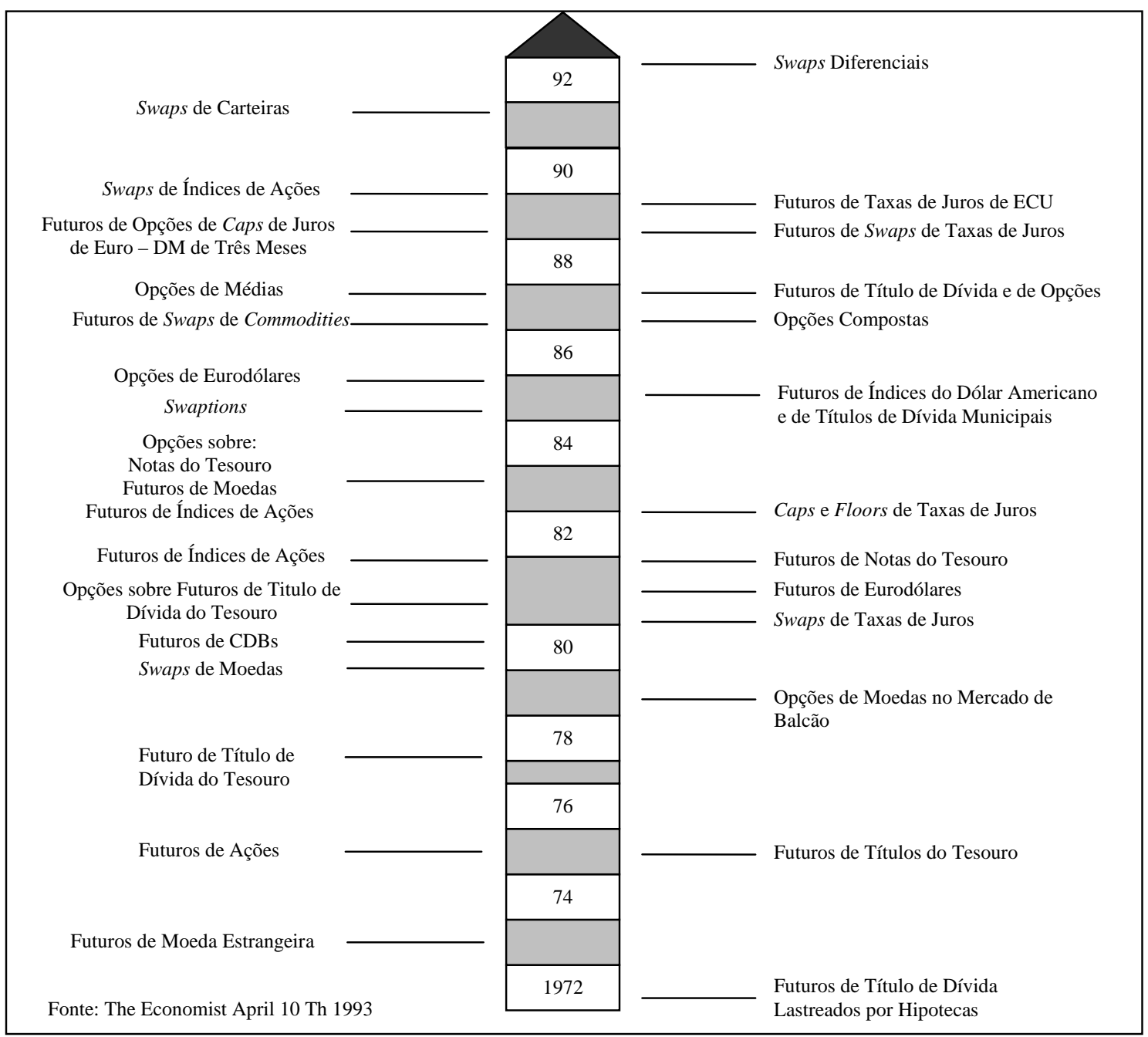

Figura 2 - Evolução de produtos para gerenciamento de risco

Uma das vantagens dos derivativos foi que permitiram reduzir o tempo e, conseqüentemente, o custo, que cada gestor gastaria em encontrar uma contraparte com uma exposição ao risco oposto. A liquidez desse mercado favorecia o encontro de agentes dispostos a suportar os 
riscos com aqueles que não estavam preparados para lidar com riscos que estivessem fora do escopo do seu negócio.

Em 1982, o Congresso Americano, com o objetivo de conhecer melhor esse mercado, solicitou um relatório à Commodity Futures Trading Commission (CFTC), à Securities and Exchange Commission (SEC), ao Federal Reserve Board e ao Departamento do Tesouro, cuja principal conclusão, A Study of the Effects on the Economy of Trading in Futures and Options de 1984, foi:

Os novos mercados financeiros de futuros e de opções servem a um propósito econômico bastante útil, qual seja, fornecer uma forma pela qual os riscos inerentes à atividade econômica - como os de mercado, de taxa de juro e de taxas de câmbio - possam ser transferidos das pessoas físicas e jurídicas que desejem evitá-los àqueles que estejam dispostos a assumí-los. Essa função desejável de transferência de risco provavelmente se estenderá a outras instituições financeiras e comerciais e aumentará em magnitude, à medida que experiência seja adquirida com esses novos mercados e impedimentos legais a seu uso sejam modificados.

Dez anos depois dessa pesquisa, o mercado de futuros mais do que quadruplicou nos EUA, segundo o FUTURES INDUSTRY INSTITUTE (1998, p. 1). Isso evidencia uma crescente preocupação e, conseqüentemente, um aumento na procura por instrumentos de proteção.

Em recente pesquisa realizada com 378 empresas não-financeiras com ações negociadas na Bolsa de Valores de São Paulo - BOVESPA, das quais apenas 74 responderam, Saito e Schiozer (2005, p. 52:53) verificaram que desse universo de 74 empresas, apenas 42 utilizavam derivativos e que houve um aumento da sua utilização, de 2002 em relação a 2001 e de 2003 em relação a 2002, sugerindo que, independentemente da volatilidade do mercado, ocorreu uma tendência crescente no uso de derivativos. 
Os resultados referentes a essa pesquisa são observados na tabela seguinte, na qual consta como se deu a segregação das 42 empresas que utilizam derivativos para cada intervalo de ano em estudo ao se considerar a intensidade do seu uso.

\begin{tabular}{|cccc|}
\hline & 2002 em relação a & 2003 em relação a & Mesma resposta \\
& 2001 & 2002 & para ambos os anos \\
\hline Uso de derivativos aumentou & $32(76,2 \%)$ & $18(42,9 \%)$ & $15(35,7 \%)$ \\
\hline Uso de derivativos diminuiu & $3(7,1 \%)$ & $8(19,1 \%)$ & $2(4,8 \%)$ \\
\hline Uso de derivativos permaneceu constante & $7(16,7 \%)$ & $16(38,1 \%)$ & $4(9,6 \%)$ \\
\hline
\end{tabular}

Fonte: Saito e Schiozer (2005, p. 55)

Tabela 1 - Variação na intensidade de uso de derivativos: 2003/2002 e 2002/2001

Ainda segundo Saito e Schiozer (2005, p. 57):

Também em linha com o que foi observado internacionalmente e de acordo com as práticas prescritas pela teoria de finanças, verificou-se que os gestores brasileiros utilizam derivativos principalmente com o propósito de proteger a empresa de riscos, e não com fins especulativos - a maioria tem mecanismos e critérios de avaliação e remuneração que não incentivam tal comportamento.

Se, no passado, as empresas eram pequenas e de características familiares, tendo, assim, como única preocupação serem boas nos negócios em que se inseriam, atualmente essa realidade é outra, pois sendo obrigadas a serem competitivas nos seus negócios, elas ainda devem aprender a lidar com variáveis antes restritas às instituições financeiras e administradoras de risco, como: taxa de juros, câmbio e indexadores. Elas ainda devem preocupar-se com o aumento da volatilidade do próprio negócio e novas variáveis dos quais o negócio pode passar a depender.

Assim, é premente que a instituição tenha políticas que direcionem suas ações visando minimizar ou eliminar os efeitos de fatores exógenos no seu lucro. Essas políticas precisam definir as condições para o emprego dos procedimentos e instrumentos, objetivando a proteção da posição em risco. 


\subsection{OBJETIVO DO TRABALHO}

Um dos derivativos mais importantes disponíveis no mercado financeiro é o que se denomina de opção. Em geral, na forma de opção de compra, que dá o direito de adquirir um ativo a um preço preestabelecido numa (até) data mediante o pagamento de um prêmio, ou opção de venda, que dá o direito de vender um ativo a um preço preestabelecido numa (até) data mediante o pagamento de um prêmio.

A principal utilização das opções é na proteção de posições em risco. São instrumentos amplamente negociados no mercado de futuros e permitem uma grande flexibilidade ao seu detentor em comparação com outros instrumentos de proteção, como: contratos futuros, contratos a termo ou swap. Segundo Hull (2002, p. 11), a principal diferença no uso de opções e no de contratos a termo como instrumentos de proteção é que esses são desenhados para a neutralização do risco através da fixação seja do preço de compra ou de venda do ativo objeto, enquanto as opções, ao contrário, são como um seguro, pois visam proteger o investidor contra os movimentos adversos dos preços, além de permitir possíveis ganhos resultantes dos seus movimentos favoráveis. Em virtude dessa característica, a política de hedge, a ser estabelecida neste trabalho, será alicerçada em opções, em especial nas opções de compra.

Assim, pode-se enunciar como objetivo deste trabalho estabelecer critérios para que as instituições não-financeiras estabeleçam suas políticas de hedge ${ }^{1}$, no sentido de controle de riscos, mediante uso exclusivo de opções de compra. Para isso, será desenvolvido um modelo quantitativo que possibilitará à empresa determinar a melhor opção de compra para ser utilizada na sua política de hedge e, conseqüentemente, estabelecer a fração ótima da sua posição em risco que deverá ser protegida mediante duas condições: a primeira uma limitação

\footnotetext{
${ }^{1} \mathbf{1}$ * o termo hedge e hedgear não existem na língua portuguesa embora sejam de uso comum na linguagem financeira. Serão utilizadas neste texto no sentido de proteção ou defesa em relação a posições de risco assumidas.
} 
orçamentária que a empresa possua para a operação de hedge; e a segunda, um valor préfixado do ativo objeto, a um dado nível de confiança, na data de vencimento da opção. 


\subsection{METODOLOGIA}

De acordo com Abramo (1979, p. 21:88), as pesquisas das ciências podem ser classificadas

das seguintes maneiras:

\begin{tabular}{|c|c|}
\hline Critério & Tipos \\
\hline $\begin{array}{l}\text { 1. Segundo a utilização dos } \\
\text { resultados }\end{array}$ & $\begin{array}{l}\text { Pesquisa pura: é a pesquisa feita para aumentar o corpo teórico da ciência ou para } \\
\text { satisfazer a curiosidade do pesquisador, sem objetivos de utilização imediata dos } \\
\text { resultados; é a obtenção do conhecimento pelo conhecimento. } \\
\text { Pesquisa aplicada: tipo de estudo motivado pela necessidade de resolver problemas } \\
\text { concretos, é a obtenção do conhecimento para transformação da realidade. }\end{array}$ \\
\hline $\begin{array}{l}\text { 2. Segundo a extensão do campo } \\
\text { de estudo }\end{array}$ & $\begin{array}{l}\text { Levantamentos: pesquisas superficiais de uma área de grande extensão para obter dados } \\
\text { que permitam construir quadros de referência e formular hipóteses, a serem utilizados } \\
\text { posteriormente em pesquisas de maior profundidade. } \\
\text { Pesquisa de profundidade: limitação da pesquisa a um tema específico, examinando o } \\
\text { maior número de variáveis que interfira no problema da pesquisa. }\end{array}$ \\
\hline 3. Segundo o nível de interpretação & $\begin{array}{l}\text { Pesquisa exploratória: busca a existência de um fato, respondendo a perguntas do tipo: O } \\
\text { que é? O que existe? } \\
\text { Pesquisa descritiva: uma vez identificado o fato, descreve-se e caracteriza-se tal fato, } \\
\text { respondendo a perguntas do tipo como é? }\end{array}$ \\
\hline 4. Segundo os processos de estudo & $\begin{array}{l}\text { Estrutural: a análise sistemática da forma, do funcionamento, dos elementos e de suas } \\
\text { inter-relações. } \\
\text { Histórico: reconstituição do desenvolvimento de um fato. } \\
\text { Comparativo: análise de fatos para a verificação de o que há em comum entre eles } \\
\text { Funcionalista: exame das relações entre fenômenos para verificar quais variações em um } \\
\text { acarretam variações no outro e como são estas variações. } \\
\text { Estatístico: exame da freqüência e da variabilidade de certos atributos. } \\
\text { Monográfico: estudo em profundidade de um único fato. }\end{array}$ \\
\hline 5. Segundo a natureza dos dados & $\begin{array}{l}\text { Pesquisa de dados objetivos: procura descrever objetivamente uma realidade. } \\
\text { Pesquisa subjetiva: procura colher não a realidade tal como ela é, mas como se apresenta a } \\
\text { determinado grupo de pessoas. }\end{array}$ \\
\hline 6. Segundo o grau de generalização & $\begin{array}{l}\text { Censitária: dados colhidos de todos os elementos do universo de pesquisa. } \\
\text { Por amostragem: dados colhidos de uma parte do todo, obedecendo a certos critérios e } \\
\text { procedimentos estatísticos. }\end{array}$ \\
\hline $\begin{array}{l}\text { 7. Segundo a procedência dos } \\
\text { dados }\end{array}$ & $\begin{array}{l}\text { Dados primários: colhidos diretamente pelo investigador. } \\
\text { Dados secundários: dados já existentes, colhidos anteriormente por outro pesquisador ou } \\
\text { instituição. }\end{array}$ \\
\hline $\begin{array}{lrll}\text { 8. Segundo os } & \text { setores } & \text { de } \\
\text { conhecimento }\end{array}$ & $\begin{array}{l}\text { Monodisciplinares } \\
\text { Multidisciplinares } \\
\text { Interdisciplinares: pesquisa sobre assuntos que estão na fronteira de dois ou mais campos } \\
\text { de conhecimento. }\end{array}$ \\
\hline $\begin{array}{l}\text { 9. Segundo as técnicas e } \\
\text { instrumentos de observação }\end{array}$ & $\begin{array}{l}\text { Observação direta } \\
\text { Observação indireta }\end{array}$ \\
\hline 10. Segundo os métodos de análise & $\begin{array}{l}\text { Construção de modelos } \\
\text { Elaboração de tipologia e classificações }\end{array}$ \\
\hline
\end{tabular}

Fonte: Adaptado de Abramo (1979, p. 21:88)

Quadro 1 - Classificação das pesquisas nas ciências 
A partir dos critérios apresentados, pode-se classificar o trabalho como uma pesquisa aplicada, pois procura solucionar problemas reais das empresas. E, ao mesmo tempo, com elementos de uma pesquisa pura que objetiva o conhecimento, pela sua grandeza, sem o objetivo de utilização imediata dos resultados.

Com relação à extensão do campo de estudo, a pesquisa é de profundidade, já que procura focar no maior número de variáveis que interfiram no problema da política de hedge de instituições não-financeiras através do uso de opções de compra. Segundo o nível de interpretação, a pesquisa classifica-se como descritiva, porque, uma vez identificado o fato, procura descrevê-lo e caracterizá-lo.

A respeito dos processos de estudo, torna-se difícil enquadrar a pesquisa em apenas um único critério já que ela possui elementos pertinentes:

- Ao estrutural, ao analisar o funcionamento dos principais elementos de uma política de hedge com o uso de calls e de suas principais inter-relações;

- Ao funcionalista pelo exame das relações entre fenômenos para verificar quais variações em um acarretam variações no outro e como são essas variações e

- Ao monográfico pelo estudo em profundidade de um único fato, que, no caso, é a política de hedge de instituições não-financeiras através do uso de opções de compra.

A pesquisa descreverá, objetivamente, uma realidade através do estudo de caso com dados primários colhidos por amostragem pela observação indireta. Por envolver um único campo de conhecimento, a pesquisa é monodisciplinar cujo método de análise será pautado através da construção de um modelo que permitirá o entendimento da política de hedge de instituições não-financeiras através do uso de opções de compra. 


\subsection{DESCRIÇÃO DOS CAPÍTULOS}

A estrutura do trabalho foi dividida da seguinte forma:

O primeiro capítulo, como introdução, busca apresentar a situação problema, contextualizando e apresentando a justificativa da pesquisa; em seguida, abordam-se o problema, os objetivos pretendidos bem como a metodologia da pesquisa.

Os dois capítulos seguintes apresentam uma revisão da literatura: o segundo trata do conceito de risco, as maneiras de classificá-lo, os tipos mais freqüentes e as suas principais medidas. O terceiro capítulo tratará do conceito de hedge, sua relação com o valor da empresa, o ativo a ser protegido, o momento mais adequado de realizá-lo e concluirá abordando os principais instrumentos disponíveis para o hedge, entre eles, contratos a termo, contratos futuros, swaps e opções.

O quarto capítulo tratará do conceito de política e dos princípios que nortearão uma política de hedge.

O quinto capítulo mostrará a metodologia desenvolvida para o estabelecimento de uma política de hedge para instituições não-financeiras utilizando opções de compra; ao capítulo sexto caberá o estudo de caso com as análises e avaliação da metodologia desenvolvida. O sétimo capítulo apresenta as conclusões e as recomendações para futuros trabalhos. 


\section{CAPÍTULO 2 - O RISCO NAS EMPRESAS}

"Lutamos realmente para reduzir a incerteza, mesmo que. não a queiramos eliminada de nossa vida."

Frank Knight

\subsection{DEFINIÇÃO DE RISCO}

De acordo com Reekie e Crook (1995, p. 33), no processo de tomada de decisão existem três graus de conhecimento dos estados da natureza: a certeza, o risco e a incerteza. A certeza existe caso haja um total conhecimento de todos os aspectos relevantes da decisão e, além disso, é conhecido o resultado de cada decisão.

A respeito dos conceitos de risco e incerteza, é importante frisar que há uma importante diferença entre ambas, apesar de as duas palavras serem sinônimas para alguns autores. Observe-se isso, por exemplo, na definição de Jorion (1998, p. 65) sobre o risco como “a incerteza em relação a resultados”.

A primeira distinção entre ambas aparece em Knight (1972, p. 249) que classifica uma incerteza em mensurável e imensurável. A incerteza mensurável que pode ser reduzida a uma probabilidade objetiva ou a algo quantitativamente determinado é chamada de risco.

Segundo Spencer, Seo e Simki, (1975, p.10), “incerteza é um fenômeno subjetivo: dificilmente dois indivíduos verão o mesmo evento e formularão a mesma opinião quantitativa”. De acordo com esses autores, existem três classes de situações de incerteza: completo conhecimento, completa ignorância e ignorância parcial.

O completo conhecimento é quando existe a distribuição da probabilidade a priori dos estados da natureza e nessa situação o problema passa a ser uma decisão sob risco. A 
completa ignorância é o oposto do completo ou perfeito conhecimento, ou seja, não se tem conhecimento das probabilidades associadas a cada estado da natureza. Por último, a ignorância parcial ocupa uma posição intermediária em relação aos dois estados anteriores. Para essa condição, reduz-se o problema da incerteza para uma decisão sob risco, mediante uma distribuição de probabilidades subjetivas.

Desta forma, a principal característica do risco é que a ele se pode associar um número que expresse a chance de ocorrência de um resultado dado que foi tomada aquela decisão. Talvez a melhor expressão que associa risco e incerteza seja de Fabozzi (2003, p. 257): “o risco é o grau de incerteza”.

A idéia popular de risco pode ser retratada por um exemplo apresentado em Sharpe, Alexander e Bailey (1998, p. 156), no qual é proposto o seguinte: "Pergunte a uma pessoa na rua para definir o risco de investimento, e ele ou ela invariavelmente se referirá como a chance de que algo ruim aconteça. Sugira para esta pessoa que o risco também tem associação com a possibilidade de ocorrência de bons resultados e certamente causará olhares descrédulos".

Outros autores, como Carvalho (1996, p. 56), definem o risco como "a probabilidade de ocorrência (ou não ocorrência) de um resultado futuro não esperado (ou esperado)”. Podem-se encontrar outras definições de risco, como a de Robert Jeffrey apud Bernstein (1997, p. 261) que exprime o risco de uma carteira como o fato de ela "não conseguir fornecer ao proprietário, quer em duração, em alguma data terminal ou em ambos, o dinheiro de que ele precisa para desembolsos essenciais“. Mas um consenso entre as várias de definições é que risco está associado a um acontecimento ou retorno diferente do esperado. 
Talvez, a idéia de risco é mais bem capturada ao representar essa palavra por símbolos chineses, que estão reproduzidos abaixo:

\section{冒險 (mào xian)}

Figura 3 - A palavra risco na escrita chinesa

O primeiro símbolo significa aventura, enquanto o segundo é a palavra perigo. A composição dessas duas palavras ilustra muito bem a essência da palavra risco, pois arriscar-se é, sem dúvida, aventurar-se ante o perigo esperando altas recompensas ou retornos. 


\subsection{TIPOS DE RISCOS}

\subsubsection{Risco Sistêmico e Não Sistêmico}

No seu famoso trabalho, Capital Asset Prices: A Theory of Market Equilibrium under Conditions of Risk, Sharpe (1964, p. 439) constatou que o risco total de qualquer ativo decorre de duas partes: uma componente denominada risco sistêmico e uma outra, por não estar correlacionada com o retorno do mercado (sistema), denominada de componente não sistêmico.

O risco não sistêmico, conhecido também como risco diversificável, é aquele próprio do negócio, que provém da empresa, e é passível de diversificação por parte dos gestores.

Por outro lado, existem riscos que estão ligados à conjuntura econômica, sendo os seus impactos muito mais abrangentes por afetar a maior parte, senão, todos os investimentos de uma economia. Como exemplos: o risco da alta na taxa de juros, um choque de oferta ou uma maxidesvalorização da moeda. Esses riscos são conhecidos como sistêmicos, não diversificáveis ou conjunturais.

A política de investimento específica, ou própria, de cada empresa, implicará em que assuma um risco não sistêmico, visto que resultados piores advindos desse investimento afetarão unicamente a empresa. Ao contrário da alteração na taxa de juros ou de um choque de demanda do petróleo que afetará o mercado inteiro (riscos sistêmicos).

Mas, existem riscos que não afetam uma única empresa e nem o mercado inteiro, mas, sim, um setor ou setores de uma economia. Dessa forma, esses riscos não podem ser simplesmente classificados, nem como sistêmicos e nem como não sistêmicos, mas se encontram numa 
região nebulosa entre essas duas classificações, por exemplo: o risco de uma ação política desfavorável ao setor calçadista.

As idéias apresentadas estão esquematizadas na figura seguinte, na qual, no extremo esquerdo, se encontram riscos específicos da empresa, ou seja, os riscos não sistêmicos, e, no outro extremo, riscos que afetariam o mercado todo, ou seja, os riscos sistêmicos. Mas haveria outros riscos que, devido à abrangência do seu impacto, estariam entre os dois extremos citados.

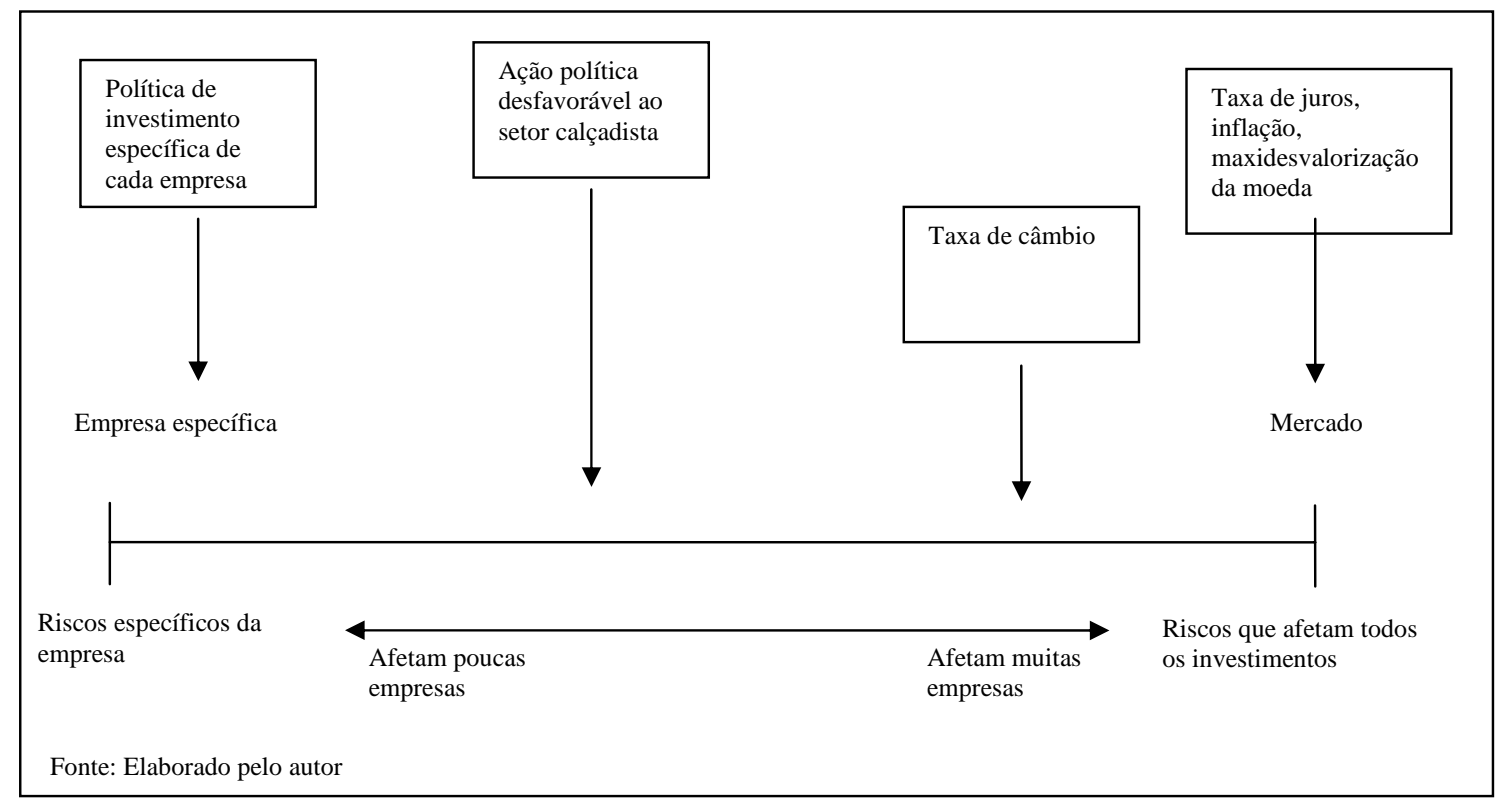

Figura 4 - Risco sistêmico e não sistêmico em relação ao mercado e à empresa

\subsubsection{Outras Classificações de Risco}

Além da classificação de risco em sistêmico ou não, existem muitas outras formas de classificação de riscos. Uma das mais utilizadas pelas instituições financeiras foi proposto pelo Global Derivatives Study Group do G30 - Grupo Consultivo sobre Economia Internacional e Questões Monetárias - no trabalho Derivatives: Practices and Principles de 
1993 que divide o risco global em quatro grandes grupos: mercado (market), crédito (credit), operacional (operational) e, finalmente, legal (legal). Esses quatro grandes grupos englobariam todos os tipos de risco aos quais as instituições estão sujeitas. É comum encontrar outros grupos e nomes para os riscos mencionados. A seguir, será detalhado cada um desses quatro grupos.

\section{a) Risco de Mercado}

Está relacionado com o preço e valor de bens, serviços, índices, commodities, entre outros. Encontra-se diretamente ligado à forma pela qual o preço de um bem ou derivativo se comporta no dia-a-dia. É o que se ganha ou se perde na compra de um determinado contrato, derivativo, ativo, pela simples mudança em seu preço, avaliado na data hoje em que se analisa o problema.

De uma forma geral, o termo risco de mercado está ligado às variações do mercado financeiro, visto que as instituições financeiras foram as primeiras a formalizarem o conceito.

Goulart (2003, p.77) classifica o risco de mercado em quatro tipos: risco do mercado acionário, risco do mercado de câmbio, risco do mercado de juros e risco do mercado de commodities.

\section{b) Risco de Crédito}

O risco de crédito está relacionado a possíveis perdas quando um dos contratantes não honra seus compromissos. Perdas, nesse contexto, correspondem aos recursos que não serão mais recebidos. 
De acordo com Duarte Júnior (2001, p.106), o risco de crédito pode ser dividido em três grupos:

- risco país;

- risco político e

- risco de não pagamento.

Cada um desses tipos de risco de crédito pode ser entendido como segue:

i) risco país: refere-se a possibilidades de mudanças de regras que envolvem o país como um todo. Segundo Gimenes e Famá (2003, p. 39), “na visão do mercado, o risco país mede a possibilidade de default de um país em relação aos seus papéis”. São os casos das moratórias de países latino-americanos e mudanças de governo;

ii) risco político: refere-se a possibilidades de mudanças de políticas de gestão dos governos que podem afetar setores da economia, segmentos de empresas ou pessoas. Podem ser originados de golpes militares, novas políticas econômicas e resultados de novas eleições. Ex: Invasão do Iraque no Kuait, aumento das taxas e impostos e criação de subsídios.

Esse risco, para Sharpe, Alexander e Bailey (1998, p. 328), refere-se

A incerteza sobre a capacidade de um investidor converter a moeda estrangeira em moeda local. Especificamente, um governo estrangeiro poderá restringir, taxar, ou proibir completamente a troca de uma moeda por outra. Pelo fato destas políticas mudarem de tempo em tempo, a capacidade de um investidor repatriar os fluxos de caixa na moeda estrangeira estão sujeitas a alguma incerteza.

iii) risco da falta de pagamento: ocorre quando uma das partes num contrato deixa de honrar os compromissos assumidos. 


\section{c) Risco Operacional}

É o risco proveniente de falhas de sistema, erro humano, falha de gerenciamento, ou simplesmente falta de controle e transparência dos sistemas adotados. Duarte Júnior (2001, p.105:106), divide o risco operacional em três grandes áreas:

i) risco organizacional: está relacionado a uma organização ineficiente, ou seja, a uma administração inconsistente e sem definição de objetivos de longo prazo, fluxo deficiente de informações internas e externas, responsabilidades mal definidas, fraudes, acesso a informações internas por parte de concorrentes, entre outros;

ii) risco de operações: diz respeito a problemas como overloads de sistemas (telefonia, elétrico, computacional, entre outros), processamento e armazenamento de dados passíveis de fraudes e erros, confirmações incorretas ou sem verificação criteriosa;

iii) risco de pessoal: refere-se a problemas, tais como: empregados não qualificados e/ ou pouco motivados, de personalidade fraca, falta de ambição, carreiristas e outras questões de atitude.

\section{d) Risco Legal}

É a possibilidade de perda devido à impossibilidade de se executarem os termos de um contrato, incluindo os riscos provenientes de documentação insuficiente, falta de capacidade ou autoridade de uma contraparte, incerteza legal e a incapacidade de se implementar uma cobrança devido à quebra ou insolvência da contraparte. Como exemplo, Jorion (2003, p.568) cita o caso da Procter\&Gamble que perdeu U\$ 157 milhões em dois swaps de taxas de juros intermediados pelo Bankers Trust, e depois acionou o Bankers Trust por falsa representação dos riscos envolvidos nas transações. 


\section{e) Outros Riscos}

Além dos riscos mencionados, Sharpe, Alexander e Bailey (1998, p. 328) citam o risco do poder de compra que “é devido a uma incerteza na inflação”. Para Francis (1993, p. 451), “é a porção da variabilidade total do ativo no retorno real (ou ajustado à inflação) que é causado pelas mudanças no nível geral dos preços. Inflação é uma causa primária do risco do poder de compra; ela reduz o poder de compra dos ativos monetários que são determinados numa quantia fixa de dólar”.

Crouhy, Galai e Mark (2004, p. 36) mencionam o risco de fator humano que, na verdade, é uma forma especial de risco operacional e "relaciona-se às perdas que podem resultar de erros humanos como apertar o botão errado em um computador, inadvertidamente destruir um arquivo ou inserir o valor errado para parâmetro de entrada de um modelo”. 


\subsection{MEDIDAS DE RISCO}

"O que não pode ser mensurado, não pode ser gerenciado.“ Lord Kelvin

Segundo Copeland e Weston (1988, p. 145), é fundamental que um risco seja corretamente mensurado, pois somente aí "nós podemos avaliar apropriadamente o valor dos ativos. Isso nos direcionaria para uma melhor alocação dos recursos da economia. Investidores poderiam fazer um melhor trabalho na alocação das poupanças nos vários tipos de ativos”.

Uma idéia intuitiva da mensuração de risco vem do exemplo de Francis (1993, p.13) em que ele cita “Um investimento cuja taxa de retorno varie amplamente de um período para outro é mais arriscado que um outro cuja taxa de retorno não mude tanto assim”. Dessa maneira, um investimento, cuja variação seja maior em torno de um valor central do que um outro, acaba implicando em um risco maior.

A medida mais aceita de risco só vem com Markowitz que, segundo Bernstein (1997, p. 252), “não faz nenhuma menção à palavra risco ao descrever sua estratégia de investimentos. Ele simplesmente identifica a variância do retorno como a coisa indesejável que os investidores tentam minimizar. Risco e variância tornam-se sinônimos [....] Markowitz quantificou o risco dos investimentos”.

Além da variância, as outras medidas mais comuns para a mensuração do risco são:

- Desvio-padrão;

- Semi desvio-padrão;

- Volatilidade;

- Coeficiente de variação; 
- $\operatorname{Beta}(\beta)$;

- Valor em risco (VAR);

- Valor em risco condicional (CVAR).

A seguir, será examinada cada uma delas:

\section{i) Desvio-Padrão $(\sigma)$}

O desvio-padrão é calculado como:

$$
\sigma=\sqrt{\sum_{i=1}^{n} P_{i}\left[x_{i}-E(X)\right]^{2}}
$$

Sendo:

$\sigma$ é o desvio-padrão;

$P_{i}$ é a freqüência relativa de $x_{i}$;

$x_{i}$ é o i-ésimo elemento da amostra;

$n$ é o número de elementos da amostra e

$E(X)$ é a esperança da amostra.

A popularização do desvio-padrão como medida de risco pode ser explicada por ela ser, computacionalmente, mais fácil de trabalhar do que qualquer outra alternativa. A principal característica dessa medida é que leva em conta todas as observações.

Sharpe, Alexander e Bailey (1998, p. 156) citam alguns problemas associados a essa medida por ela "caracterizar insuficientemente o risco de um ativo com assimetria positiva, ignorando o fato de que a maior parte da volatilidade do ativo esteja no lado bom”. É uma medida de 
risco total do ativo, ou seja, leva em consideração tanto a componente relacionada ao risco sistêmico quanto a componente associada ao risco não sistêmico.

\section{ii) Semi Desvio-Padrão $\left(\sigma_{k}\right)$}

O desvio-padrão pondera, igualmente, tanto resultados acima ou abaixo da média. Mas, muitas vezes, a preocupação recai somente nos resultados indesejáveis que, na maioria, se situam abaixo da média. Em virtude disso, ao invés de usar o desvio-padrão, pode-se utilizar o semi desvio-padrão cujo cálculo é semelhante ao do desvio-padrão, mas apenas os retornos abaixo do retorno esperado são usados para o cálculo.

Definindo, $k$ como o número de observações com o retorno abaixo do esperado. Esta medida é calculada como:

$\sigma_{k}=\sqrt{\sum_{i=1}^{k} P_{i}\left(x_{i}-E(X)\right)^{2}}$

Sendo,

$\sigma_{k}$ é o semi desvio-padrão;

$P_{i}$ é a freqüência relativa de $x_{i}$;

$x_{i}$ é o i-ésimo elemento da amostra e

$E(X)$ é a esperança da amostra.

\section{iii) Volatilidade}

A volatilidade é o desvio-padrão do logaritmo neperiano dos preços de um dado ativo.

A volatilidade é calculada como: 
$V=\sqrt{\sum_{i=1}^{n-1} P_{i}\left[\operatorname{Ln}\left(\frac{x_{i+1}}{x_{i}}\right)-\frac{\sum_{j=1}^{n-1} \operatorname{Ln}\left(\frac{x_{j+1}}{x_{j}}\right)}{n-1}\right]^{2}}$

Sendo:

$V$ é a volatilidade;

$P_{i}$ é a freqüência relativa de $x_{i}$;

$X_{i}$ é o i-ésimo elemento da amostra de preços e

$n$ é o número de elementos da amostra.

\section{iv) Coeficiente de Variação (CV)}

Considere a situação em que dois ativos possuam o mesmo desvio-padrão, mas com diferentes retornos médios. Pode-se calcular uma relação do risco incorrido para cada unidade de retorno obtida e essa medida é o coeficiente de variação, calculado como:

$C V=\frac{\sigma}{\mu}$

Sendo:

$C V$ é o coeficiente de variação;

$\sigma$ é o desvio-padrão e

$\mu$ é o retorno esperado.

Logo, um maior valor de CV implicará em um risco maior. 


\section{v) Beta $(\beta)$}

Uma outra maneira de medir o risco de um ativo é através da divisão da covariância do retorno do ativo com o retorno da carteira de mercado pela variância da carteira de mercado. Isso resulta numa medida de risco conhecida como o Beta do ativo. Ele é calculado como:

$\beta=\frac{\operatorname{Cov}_{i m}}{\sigma^{2}{ }_{m}}$

Sendo:

$\beta$ é o beta do ativo $i$ com a carteira de mercado $m$;

$\operatorname{Cov}_{\text {im }}$ é a covariância do retorno do ativo $i$ com o retorno da carteira de mercado $m$ e $\sigma_{m}^{2}$ é a variância da carteira de mercado $m$.

Essa medida compara o risco de um ativo em relação ao risco do mercado. Ativos mais arriscados que a média do mercado terão betas maiores do que um e ativos que são menos arriscados que a média do mercado terão betas menores que um. Por construção, o beta do mercado será igual a um enquanto o beta do ativo livre de risco igual a zero. Trata-se de uma medida de risco sistêmico, ou seja, a componente do risco total que não pode ser diversificada através da montagem de uma carteira.

\section{vi) Valor em Risco (VAR)}

O Valor em Risco (VAR) é uma das medidas muito popularizada pelas instituições financeiras. Mas ele tornou-se público apenas em outubro de 1994, quando o Banco J.P. Morgan \& Co. apresentou ao mercado a sua metodologia para o cálculo do risco. 
Jorion (1998, p. vii) define o VAR como sendo a "pior perda esperada ao longo de determinado intervalo de tempo, sob condições normais de mercado e dentro de determinado nível de confiança”.

No caso mais geral, o VAR é definido em Jorion (1998, p. 84) como:

$\alpha=\int_{V A R}^{\infty} f(x) d x$

Sendo:

$\alpha$ é o nível de confiança associado ao VAR e

$f(x)$ é a função densidade de probabilidade da variável $x$.

Graficamente, tem-se:

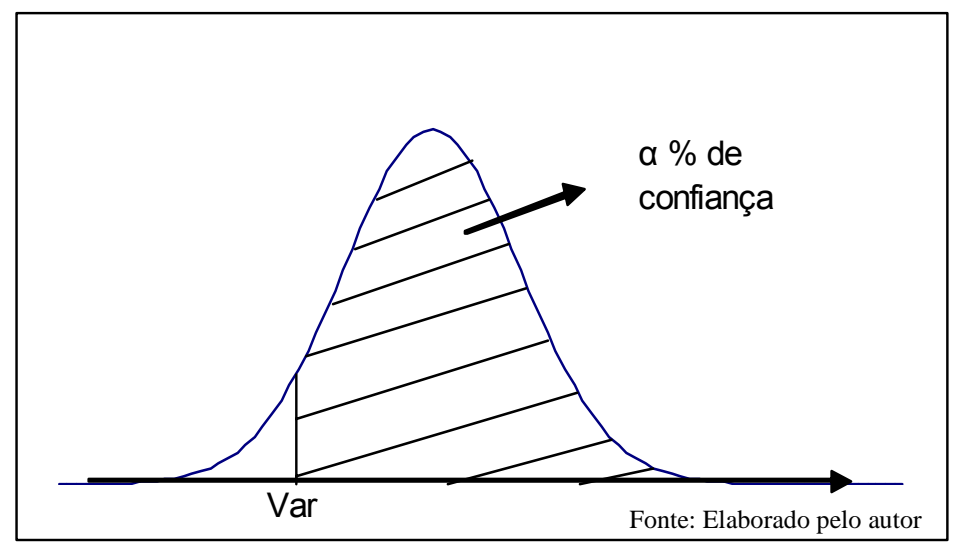

Figura 5 - Cálculo do VAR

O VAR, dessa maneira, nada mais é do que um valor medido em unidades monetárias que corresponde a um percentil escolhido da função densidade de probabilidade da variável $x$. 
O VAR pode ser calculado utilizando três metodologias:

- VAR Histórico;

- VAR Paramétrico e

- VAR Monte Carlo.

A seguir, será analisado cada um deles:

i) VAR Histórico

Envolve o uso de dados históricos como meio de estimar o futuro. Para calcular o VAR por esse método, deve-se, inicialmente, identificar os fatores de risco na carteira, entre eles, por exemplo: taxa de juros, taxa de câmbio, entre outros; identificando esses valores, procede-se, então, à coleta de dados históricos referentes aos fatores de risco para possibilitar a construção de vários cenários e, assim, calcular o valor da carteira para cada cenário. Isso definirá uma distribuição de probabilidade que possibilitará a determinação do VAR mediante o percentil desejado de confiança.

\section{ii) VAR Paramétrico}

Na maior parte dos casos, a utilização desse método implica supor que a distribuição dos retornos seja normalmente distribuída. Respeitando-se essa suposição e utilizando a relação para a normal padronizada, tem-se que:

$Z=\frac{\frac{P_{1}-P_{0}}{P_{0}}-\mu}{\sigma}$

Sendo:

z é uma variável com distribuição Normal com média igual a zero e desvio-padrão igual a um; 
$P_{i}$ é o valor da carteira no momento $i$;

$\mu$ é a média dos retornos diários da carteira e

$\sigma$ é o desvio-padrão dos retornos diários da carteira.

Admitindo que as observações dessa amostra sejam independentes, têm-se que o valor da carteira no momento $n$ será dado por:

$$
\begin{aligned}
& \frac{P_{n}-P_{0}}{P_{0}}=\mu n+z \sigma \sqrt{n} \\
& P_{n}=P_{0}+P_{0}(\mu n+z \sigma \sqrt{n})
\end{aligned}
$$

Calculando a variância de $P_{n}$, tem-se:

$$
\begin{aligned}
& \sigma^{2}=\sigma^{2}\left(P_{0}+P_{0}(\mu n+z \sigma \sqrt{n})\right) \\
& \sigma^{2}=\sigma^{2}\left(P_{0} z \sigma \sqrt{n}\right)
\end{aligned}
$$

Como $\sigma^{2}(z)=1$, resulta que:

$$
\sigma\left(P_{n}\right)=P_{0} \sigma \sqrt{n}
$$

A partir da equação acima, define-se VAR como:

$$
V A R=P_{0} k \sigma \sqrt{n}
$$

Sendo $k$ é o fator de confiança associado ao nível de confiança escolhido.

No caso de uma carteira composta de $n$ ativos, o VAR será calculado por:

$$
V A R=P_{0} k \sqrt{\left(\sum_{j=1}^{n} \sum_{i=1}^{n} \rho_{i j} w_{i} w_{j} \sigma_{i} \sigma_{j}\right) n}
$$

Sendo: 
$w_{i}$ é a participação percentual ou o peso do ativo $i$ na carteira;

$\sigma_{i}$ é o desvio-padrão do ativo $i$;

$\rho_{i j}$ é o valor da correlação da taxa do ativo $i$ com a taxa do ativo $j$ e

n é o número de ativos na carteira.

\section{iii) VAR Monte Carlo}

Uma outra maneira de calcular o VAR de uma carteira é através da simulação de Monte Carlo. Nesse método, o VAR é calculado utilizando a distribuição de probabilidades do valor final da carteira, e essa é encontrada através da construção de diversos cenários mediante o sorteio aleatório dos valores dos ativos da carteira. Cabe lembrar que o valor de uma carteira formada por $n$ ativos é dado por:

$P=\sum_{i=1}^{n} w_{i} \cdot \operatorname{ativo}_{i}$

Sendo:

$w_{i}$ é a participação percentual ou o peso do ativo $i$ na carteira e ativo $_{i}$ é o valor do ativo $i$.

Atualmente, muitos softwares realizam a simulação via Monte Carlo, dentre eles, o mais conhecido no mercado é o Crystal Ball.

Como vantagem, o VAR, segundo Jorion (2003, p.244), é “um número que agrega o risco da carteira inteira levando em conta a diversificação e alavancagem e provendo uma medida de risco com uma probabilidade associada”. 
Por outro lado, entre alguns problemas associados com o VAR têm-se: caudas gordas, liquidez de mercado e variação de parâmetros em períodos de crise. Além disso, de acordo com Jorion (2003, p.249), “em particular, o VAR de uma carteira pode ser maior que soma do VAR das subcarteiras”. Contudo, assumindo uma distribuição normal, o VAR baseado no desvio-padrão, satisfaz as propriedades de sub-aditividade. Por essa propriedade, o risco de uma carteira precisa ser menor do que ou igual à soma do risco das partes, isso devido ao efeito da diversificação, em que, além do risco das partes, considera-se o efeito da correlação. Uma forma de solucionar o problema da sub-aditividade é utilizar o CVAR.

\section{vii) CVAR (Conditional VAR)}

Jorion (2003, p. 250) propõe o VAR condicional (CVAR) que nada mais é do que o valor esperado da perda dado que o valor da perda tenha excedido o VAR. Formalmente o CVAR é

$$
E[x / x<V A R]=\frac{\int_{-\infty}^{V A R} x f(x) d x}{\int_{-\infty}^{V A R} f(x) d x}
$$

Perceba que essa relação é simplesmente uma esperança condicionada. Além de CVAR, essa razão é também chamada de perda esperada da cauda (expected tail loss) ou também perda condicional (conditional loss).

\section{viii) Outras medidas de risco}

Sharpe, Alexander e Bailey (1998, p. 157) citam outras medidas de risco, conhecidas como medidas de risco de queda. Essas medidas são fornecidas pela família de estatísticas conhecidas como lower shortfall moments. Por exemplo, o mean shortfall mede o desvio 
médio dos retornos abaixo do retorno esperado, enquanto o shortfall probability diz apenas quão provável o retorno do ativo possa ser abaixo do retorno esperado.

As vantagens dessas medidas de risco, citadas em Sharpe, Alexander e Bailey (1998, p. 157), decorrem do fato de elas serem

[...] mais flexíveis em aplicações do que as medidas tradicionais de risco. Contudo, as medidas de risco de queda ignoram a natureza dos possíveis resultados do investimento acima de um retorno alvo. Uma alternativa para o uso das medidas de risco de queda é trazer diretamente a assimetria na avaliação do investimento. Se dois investimentos têm o mesmo retorno e desvio padrão, o que tiver mais assimetria positiva será o preferido.

Por último, é apresentada, na figura seguinte, uma visão evolutiva das principais ferramentas de gerenciamento de risco ao longo de sessenta anos, a partir de 1938.

\begin{tabular}{|ll|}
\hline 1938 & Duration de Bond (Bond Duration) \\
1952 & Abordagem Média-Variância de Markowitz \\
1963 & CAPM de Sharpe \\
1966 & Modelo de Múltiplos Fatores \\
1973 & Modelo de Precificação de Opções de Black - Scholes (Gregas) \\
1988 & Ponderação dos riscos dos ativos pelos bancos \\
1993 & Valor em Risco (VAR) \\
1994 & RiskMetrics \\
1997 & CreditMetrics, CreditRisk+ \\
1998 & Integração do Risco de Mercado e de Crédito \\
1998 & Risco Orçamentário (Risk Budgeting) \\
\hline
\end{tabular}

Fonte: Jorion (2003, p.245)

Figura 6 - A evolução das ferramentas de gerenciamento do risco 


\subsection{O RISCO NAS INSTITUIÇÕES FINANCEIRAS}

Segundo John Hunkin, Presidente do Conselho e Principal Executivo do Canadian Imperial Bank of Commerce, apud Crouhy, Galai e Mark (2004, p. 1) “para uma instituição financeira, risco é um custo de se fazer negócios e, conseqüentemente, a melhor prática na gerência de riscos é um benefício para nossos acionistas”.

Ao longo dos últimos 20 anos, muitas corporações estão constatando ser menos custoso levantar dinheiro junto ao público do que tomar recursos diretamente dos Bancos. Em contra partida, os Bancos competem cada vez mais ferrenhamente, reduzindo suas margens de lucro e emprestando em maior volume, com prazos mais longos e a clientes de menor qualidade de crédito. Segundo Securato (2000, p. 2), “esta desintermediação fica caracterizada pela emissão de títulos de dívidas das empresas, debêntures, bônus e outros [...] é o conceito de securitização em seu sentido amplo ou, quando com garantias de recebíveis, o conceito de securitização no sentido restrito e mais conhecido nos mercados”.

Os clientes, por sua vez, exigem meios mais sofisticados para financiar as suas atividades, dentre elas: fazer hedge de seus riscos financeiros e de investir seus ativos. Essas atividades exigem conhecimento especializado e know-how cada vez melhor de controle e precificação dos riscos.

Logo, com a evolução do setor bancário, houve a passagem da ênfase do lucro e dos spreads em direção à intermediação de risco. Assim, não basta mais cobrar uma elevada taxa de juros sobre o empréstimo; a questão relevante é se os juros cobrados remuneram, adequadamente, o custo do capital ajustado ao risco. 
Com relação aos riscos enfrentados por esse setor, o risco clássico é o risco de crédito, que é aquele que envolve a mudança na qualidade creditícia do tomador e que pode impactar no valor da posição do Banco. Apesar da sua importância, foi apenas em 1988 que o Banco para Compensações Internacionais (BIS) determinou as regras para dimensionamento de capital em âmbito mundial para cobrir riscos de mercado conforme o Acordo de Basiléia. Esse foi o primeiro esforço internacional para lidar com a crescente exposição das instituições financeiras a riscos, especialmente em relação ao risco de ativos fora do balanço, como os instrumentos derivativos.

Segundo Jorion (1998, p. 41) “o histórico Acordo de Basiléia de 1988, estabelece exigências mínimas de capital [...] como prevenção contra o risco de crédito. Em suas propostas mais recentes (abril 1995), os Bancos Centrais reconheceram, inquestionavelmente, que os modelos de administração de risco utilizados pelos principais Bancos são superiores a qualquer modelo que eles mesmos pudessem propor”.

O acordo do BIS, de 1988, foi seguido pelo acordo do BIS, de 1998, referente à cobertura de riscos de carteira. Seguiram, também, muitos documentos do BIS versando as muitas facetas da gerência de risco.

Além do risco de crédito, o risco bancário envolve o risco de mercado, o risco de liquidez, o risco operacional e o risco legal. Em um Banco, o risco de mercado decorre da possibilidade de perdas decorrentes de mudanças nos preços e nas taxas no mercado financeiro. O risco relacionado com a capacidade da instituição financeira em levantar recursos necessários para rolagem de posições ou a incapacidade dela em executar uma transação ao preço de mercado fazem parte do risco de liquidez. Já o risco operacional numa instituição financeira ou não- 
financeira está relacionado a perdas potenciais resultantes de sistemas inadequados, falhas na gerência, controles defeituosos, fraude e erro humano.

Em vista dos fatores apresentados, em todo o mundo, o setor bancário é regulado de várias formas e através de muitas entidades governamentais. Os reguladores procuram evitar qualquer efeito sistêmico, através do qual a falência de um Banco se propagaria pelo resto do sistema financeiro como um efeito dominó conturbando as economias do país, ou mesmo do mundo, e incorrendo em pesados custos sociais.

Dois pontos devem ser mencionados a respeito do risco nas instituições financeiras: atualmente existe um reconhecimento mundial da necessidade de medir e controlar riscos em atividades bancárias globais e locais e a regulamentação está convergindo e se tornando mais consistente em todos os países. 


\subsection{O RISCO NAS INSTITUIÇÕES NÃO-FINANCEIRAS}

Da mesma forma que as instituições financeiras, toda instituição não-financeira está exposta a riscos em suas atividades. Os lucros sobem e descem devido a mudanças no ambiente empresarial, essas mudanças podem advir da concorrência, de novas tecnologias ou de fatores que afetam os fornecedores ou compradores.

Diante disso, as empresas não ficam impassíveis, mas respondem de diversas maneiras. Elas podem, por exemplo, deter gargalos de matéria-prima em caso de interrupções inesperadas de fornecimento, ou deter estoques de produtos acabados para atender aumentos inesperados de demanda, podem assinar contratos de fornecimento de longo prazo a um preço fixo, ou negociar contratos de longo prazo com clientes importantes. Assim, muitas fusões horizontais e verticais têm por finalidade reduzir as incertezas.

A figura seguinte mapeia, em termos gerais, os riscos de uma empresa, mostrando os riscos decorrentes de questões relacionadas a ativos e operações e aquelas atribuídas à estrutura financeira da empresa.

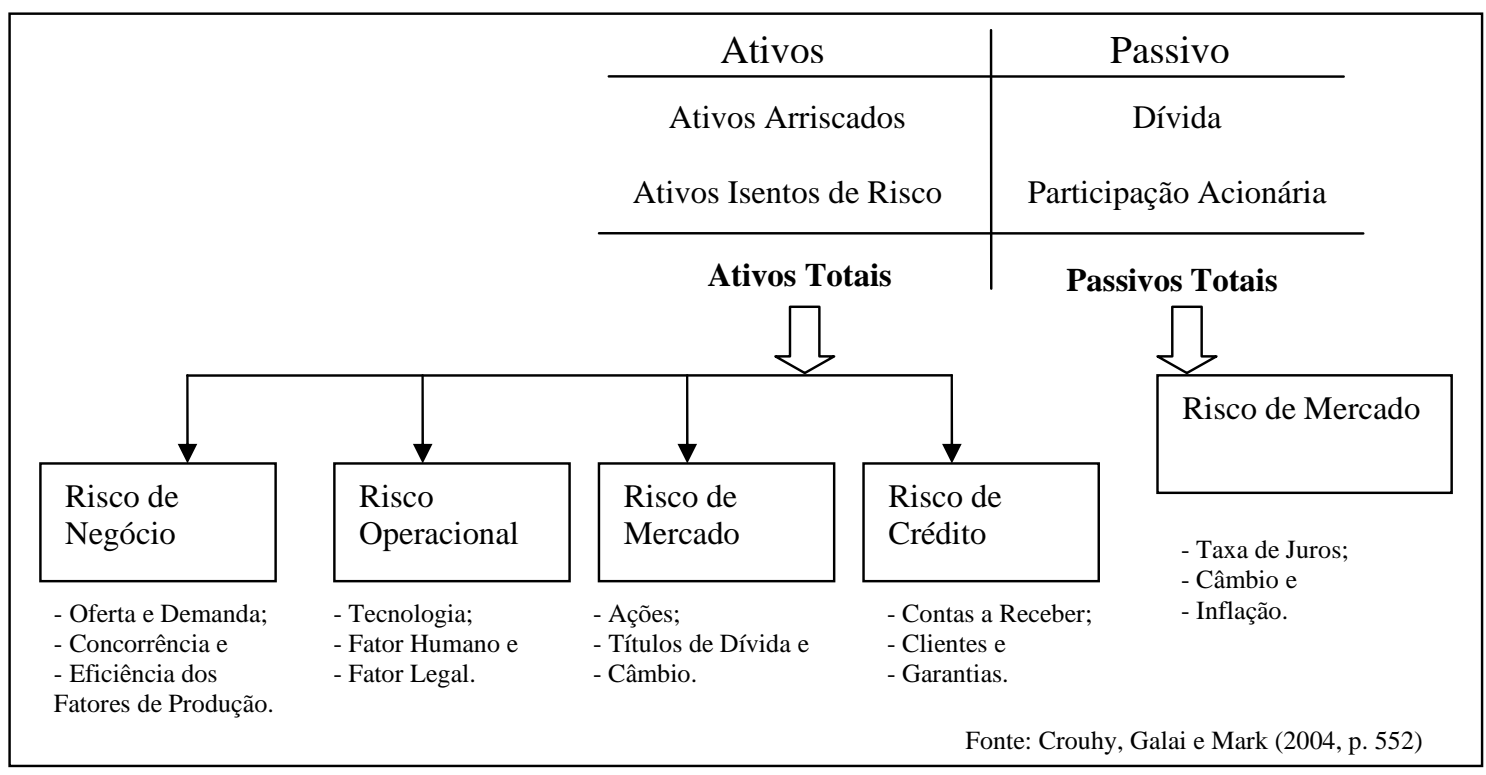

Figura 7 - Abordagem do gerenciamento de risco para toda empresa 
Observe que, no caso dos Bancos, a maioria dos riscos relacionados aos ativos envolve riscos de mercado e crédito, embora os riscos operacionais e de negócios também devam ser considerados. No caso das instituições não-financeiras, além dos riscos de mercado e de crédito, são muito importantes os riscos do negócio e os riscos operacionais.

Assim as questões de risco enfrentadas por corporações são diferentes das enfrentadas por instituições financeiras. Geralmente, aquelas precisam examinar o risco ao longo de um período de mais tempo e devem examinar como combinar os efeitos de suas exposições de risco às de qualquer hedge que tenham implantado. Os efeitos de risco sobre o planejamento e orçamento devem, também, ser considerados, juntamente com a necessidade de a empresa considerar lucros e perdas.

Da mesma maneira que os Bancos, as corporações são, freqüentemente, expostas a risco de taxas de juros. Também podem se expor ao risco de moeda estrangeira se exportam seus produtos ou serviços ou se dependem de suprimentos estrangeiros ou vinculados à moeda estrangeira. A maioria das empresas precisa ter em conta perdas potenciais que possam surgir de qualquer inadimplência de contas a receber por parte de seus clientes, e podem, igualmente, incorrer em risco de crédito se comprarem títulos de dívida corporativos ou se engajarem em negociações de derivativo. Não obstante, as exposições a risco de empresas não-financeiras, geralmente, não são regulamentadas com o mesmo rigor que a relativa ao risco dos Bancos e de outras instituições financeiras. 
Segundo Crouhy, Galai e Mark (2004, p. 38) “essencialmente, isso ocorre porque o principal risco de instituições não-financeiras é o risco do negócio, enquanto riscos de mercado e riscos de crédito são de importância secundária”.

Do exposto, parece que a principal diferença no gerenciamento de risco entre instituições financeiras e não-financeiras é que as primeiras são reguladas e obrigadas por seus reguladores a gerenciar seus riscos de crédito, mercado e operacional, e a deter capital suficiente em relação a possíveis perdas. Enquanto as últimas, não estão sujeitas a regulação semelhante e nem precisam deter um capital mínimo. De acordo com Petersen e Thiagarajan (2000, p. 5), “a mensuração das exposições ao risco nas empresas não-financeiras tem recebido limitada atenção”. Mas segundo Crouhy, Galai e Mark (2004, p. 544)

A questão do gerenciamento de risco nas NBCs (NonBanks Corporations) está ganhando força e exigindo a atenção da alta gerência das empresas, bem como dos participantes do setor de investimentos. O processo está sendo alimentado pelos avanços feitos pelo setor bancário na área de gerenciamento de risco, pela expansão dos mercados financeiros e pela gama de instrumentos de proteção ao risco hoje existentes. Um fator de contribuição é a preocupação que as diretorias começam a demonstrar em relação aos procedimentos e controles gerenciais internos; os diretores sabem que podem ser responsabilizados se a empresa for exposta a risco indevido em razão de más práticas de gerenciamento de risco. 


\section{CAPÍTULO 3 - O HEDGE NAS EMPRESAS}

\subsection{A EMPRESA E O SEU NEGÓCIO}

Besanco, Dranove e Sharnley (2000, p. 43:69) dividem a evolução da moderna empresa em três pontos no tempo: 1840, 1910 e a empresa dos dias atuais. A divisão proposta baseou-se na atividade econômica e na organização do negócio ao longo da história. Segundo esses autores, o período anterior a 1840, restringia a operação das empresas a pequenos mercados locais. Contudo, mudanças, principalmente na infra-estrutura, fizeram com que as empresas repensassem o seu negócio.

Até 1840, as pequenas empresas familiares predominavam com poucas exceções, tais como: empresas têxteis, fabricantes de relógios e armas. Isso era a conseqüência direta das limitações nos transportes, meios de comunicação e conhecimentos financeiros. Além disso, a falta de conhecimento sobre preços, compradores, vendedores e os riscos associados moldavam a natureza dos negócios. Dada a grande incerteza sobre o valor da produção, não é surpresa a relutância do empreendedor em utilizar os seus recursos na expansão da capacidade produtiva. Por razão similar, os Bancos não estavam dispostos, ou talvez preparados, para financiar a expansão dos negócios.

Em 1910, com exceção de alguns setores, como a agricultura e o ramo têxtil, as pequenas empresas ainda predominavam, mas elas já se deparavam com um conjunto mais bem desenvolvido de compradores, vendedores e de serviços que facilitavam o comércio e a circulação da informação. Houve o desenvolvimento da tecnologia de produção em massa que permitia produzir mais por menos. Paralelamente, construíram-se as ferrovias para o escoamento da produção, desenvolveu-se o telégrafo e o telefone para a comunicação e para o controle e coordenação da produção e, na área financeira, havia recursos disponíveis para 
financiar as empresas. O alto volume de produção fazia as empresas se integrarem verticalmente, devido a maiores vulnerabilidades nas falhas da cadeia de suprimento e distribuição.

Atualmente, as estratégias efetivas no passado não surtem mais efeito no mundo globalizado. Empresas que se alicerçavam em altos volumes de produtos padronizados associados com baixo custo tiveram que se adaptar a um mercado de nicho composto de produtos do tipo tailor-made a um preço baixo.

Algumas empresas abandonaram a verticalização e a tradicional estrutura hierárquica. Segundo Stalk, Evans e Shulman (1992) apud Besanco, Dranove e Sharnley (2000, p. 60) “o aumento da competição em muitas empresas estabeleceu um prêmio para antecipações nas mudanças da demanda e para a rápida transformação de idéias em produtos comercializáveis”.

Slywotzky e Morrison (1998, p. 33) afirmam que “hoje, o lucro é resultado de uma concepção do negócio inteligente [...] sem uma compreensão clara de como a empresa gera lucro e de como deve ser concebida para captar o lucro, não haverá lucro”. Assim, a compreensão do negócio torna-se fundamental para que a empresa foque naquilo em que é realmente boa e conquiste uma vantagem competitiva duradoura. Ainda, segundo Slywotzky e Morrison (1998, p. 35) “no novo mundo centrado no lucro, uma participação de mercado maciça não é importante. O que importa é compreender onde é possível gerar lucro em seu setor”.

Porter (2002, p. 23) afirma que “o desempenho de qualquer empresa é motivado pela rentabilidade derivada do negócio e pela rentabilidade resultante da posição que a companhia 
ocupa no âmbito de sua competência principal”. Ou seja, a rentabilidade de qualquer empresa está intrinsecamente ligada naquilo que ela faz de melhor. Saber fazer o melhor, significa uma maior produtividade e uma maior qualidade, e significa, também, entender melhor os riscos do negócio e assim gerenciá-los de uma maneira mais eficiente.

Isso mostra que a compreensão clara daquilo que a empresa faz de melhor, da sua competência principal, precede o hedge. Somente depois disso é que se devem adotar as estratégias e os instrumentos mais adequados a uma política de hedge. 


\subsection{O CONCEITO DE HEDGE}

A palavra hedge, no dicionário Cambridge, traz um significado "de proteção, controle ou limitação [...] Fazer hedge é também procurar evitar algo através de uma resposta ou tomando alguma ação [...] se você faz hedge das suas apostas, você se protege contra perdas por suportar mais do que um resultado possível”.

Segundo Working (1962, p. 436), no conceito tradicional, o processo de hedge "consiste em compensar um risco com um risco oposto, e o hedge em futuros é eficaz devido as mudanças do preço à vista tender a ser acompanhados da mesma forma pelas mudanças nos preços futuros“.

Corroborando com a visão de Working, o Glossary of Trading Terms (1982, p.14) entende que o hedge é “a tomada de posição em mercado futuro oposta a posição assumida no mercado à vista, para minimizar o risco de perda financeira decorrente de alterações de preços adversas; a compra ou a venda de futuros como substituta temporária de uma transação à vista que venha a ocorrer mais tarde”.

De uma forma mais ampla, não se restringindo ao mercado futuro, Oster (1981) apud Forbes (1994, p. 37:38) define o hedge como:

[...] a administração do risco. Em sentido amplo, o hedge não é feito apenas no mercado de futuros [...] usar tanto o mercado físico quanto o de futuros, você estará reduzindo o risco [...] nos movimentos abruptos de preços. Fazer hedge é assumir posição igual e oposta nos mercados à vista e futuro...Fazer hedge é proteger-se contra os riscos de preços das commodities produzidas ou que precisam ser adquiridas para o giro do próprio negócio. 
Logo, realizar hedge implica no controle, na limitação ou na redução da exposição da empresa à volatilidade dos preços e/ou à flutuação das taxas utilizando, geralmente, instrumentos derivativos. Muitas vezes, emprega-se o termo imunização como sinônimo de hedge.

Assim, o hedge é semelhante a um seguro, pois garante o fluxo de caixa necessário para obrigações vincendas; através dele, obtém-se, de acordo com, Jorion (1998, p. 8) uma “[...]proteção contra os efeitos adversos das variáveis sobre as quais as empresas e os países não têm controle”.

Numa operação típica de hedge existem, basicamente, dois participantes. Um deles, o hedger, é aquele que procura o hedge como meio de proteção e o outro, o especulador, que ao assumir o risco do hegder acaba sendo o responsável por promover liquidez ao mercado, à medida que busca lucro para as suas transações.

Por conseguinte, a principal diferença entre o especulador e o hedger é que o primeiro não possui uma posição de risco inicial: ele a estabelece ao comprar ou vender ativos ou derivativos, na expectativa de auferir lucro. O hedger, por outro lado, tem uma posição de risco inicial, resultante de alguma atividade comercial ou de investimento. Assim, é comum dizer que ele está comprado ou vendido em um ativo e, por isso, precisa operar na condição contrária fazendo o hedge.

Smith e Stulz (1985, p. 392) procuram transmitir o conceito de hedge em termos da covariância do valor de mercado da firma com uma dada variável. Isso pode ser mais bem entendido através do exemplo seguinte:

Seja V(S) o valor da firma sem hedge, onde S é um vetor das variáveis de estado. Considere duas firmas, a e b, que diferem da firma com valor V(S) 
apenas pelas suas políticas de hedge. Dizemos que a firma a faz mais hedge com respeito a variável de estado i, que a firma b, se o valor absoluto da covariância do valor da firma a com a variável de estado i é menor ou igual ao da firma b. Portanto, o hedge reduz a dependência do valor da firma em relação às mudanças da variável de estado. 


\subsection{O HEDGE E O VALOR DA EMPRESA}

Considere uma empresa e o seu negócio com os riscos inerentes, ou seja, um conjunto de posições compradas e vendidas; em um grande número de ativos. Por exemplo, uma fábrica de veículos pode ser entendida como comprada em todo o conjunto de carros estocados em seu pátio e, naturalmente, precisa vendê-los. Se a fábrica mantiver uma rede de lojas de sua propriedade, para a venda dos carros, ela estará correndo o risco da posição comprada no ativo carro e, conseqüentemente, o risco de não conseguir vendê-los. Mas se a mesma fábrica vender uma frota de caminhões para o exército para entrega em um ano, ela terá o risco de fabricá-los nas condições e prazos contratados. Logo, a grande questão da empresa está na definição do seu negócio.

Pois, se a fábrica considera seu negócio fabricar e fazer a venda direta, ela terá os riscos correspondentes e um determinado valor dado pelo valor presente de seus fluxos de caixa. Por outro lado, se essa fábrica considera que seu negócio é apenas fabricar e faz um hedge das suas vendas, ou seja, através de um contrato determina-se a obrigação da venda dos automóveis para uma rede de revendedoras, ocorrerá aí uma mudança no valor da empresa. Nessa situação, os fluxos de caixa não terão a contrapartida da receita decorrente da venda ao consumidor final implicando num menor valor dos fluxos de caixa.

Assim o ato de fazer hedge está intimamente ligado à questão de uma despesa. O hedge de posições para o negócio da empresa deve ser entendido como um insumo correspondente a uma despesa do negócio. Essa situação gera questões sobre: a eficácia do hedge em adicionar ou não valor à empresa e aos principais argumentos a favor e contrário a cada uma das correntes? Visando discutir e trazer um pouco de luz a essas questões, a seguir, serão tratados os principais aspectos do hedge na visão da teoria moderna das finanças. 


\subsection{ARGUMENTOS DE QUE O HEDGE NÃO CRIA VALOR PARA A EMPRESA}

Basicamente, existem três argumentos de que o hedge não cria valor para a empresa. Eles se apóiam na teoria da paridade do poder de compra, na proposição de irrelevância de Modigliani \& Miller do financiamento sobre a estrutura de capital de uma empresa e no CAPM de Sharpe. O que todos eles têm em comum é o mercado financeiro perfeito. Assim, antes de apresentar cada um dos argumentos citados, tornam-se imprescindíveis algumas palavras do que seja um mercado financeiro perfeito.

As premissas, nesse mercado, segundo Butler (2000, p. 328) são:

- Não há fricções, implicando que:

$\checkmark$ Não há custos de transações: seja com taxas de corretagem, seja com efeitos de pressão nos preços;

$\checkmark$ Não há impostos e nem outras formas de intervenção governamental;

$\checkmark$ Não há custos de desastres financeiros, ou seja, o risco da falência não tem efeito no fluxo de caixa;

$\checkmark$ Não há custos de agência: administradores procuram maximizar o valor dos acionistas sempre;

$\checkmark$ Não há custos pelas informações.

- Todos têm igual acesso aos preços de mercado, ou seja:

$\checkmark$ Existe uma perfeita competição implicando que nenhum participante pode influenciar os preços do mercado;

$\checkmark$ E não existem barreiras de entrada ou outras restrições para o fluxo de capital.

- Todos os investidores são racionais, percebendo mais retorno como algo bom e mais risco como algo ruim. 
- Existe uma atuante arbitragem que força, rapidamente, ao equilíbrio os preços dos ativos que são equivalentes em risco e retorno.

É importante que se aperceba da existência de inúmeras diferenças do mercado perfeito em relação ao real, pois esse é um dos principais argumentos daqueles a favor de que o hedge acrescentaria valor à empresa. Butler (2000, p. 328) afirma que “a existência das imperfeições nos mercados financeiros é a condição necessária para que o hedge corporativo tenha valor!”. Segue-se a descrição de cada um dos três principais argumentos contrários ao hedge.

a) Paridade do Poder de Compra (PPP)

De acordo com a PPP, alterações na taxa de câmbio compensariam as mudanças nos níveis de preço. Assim, uma desvalorização cambial acompanhará um aumento do nível de preços e vice-versa, ou seja, as perdas incorridas em virtude do movimento desfavorável do câmbio seriam compensadas com o movimento favorável do nível de preços. Em vista disso, não haveria um risco de perdas para a empresa e, portanto, nenhum motivo para a empresa incorrer no hedge.

De acordo com Famá e Chaia (2001, p. 61), “estudos empíricos realizados em diversos países para testar a eficiência da Teoria da PPP não têm apresentado, em geral, os resultados esperados. Apesar desta teoria não explicar corretamente o comportamento futuro da taxa de câmbio à vista, ela pode ser considerada como um bom indicador dos movimentos esperados dessas taxas”. Em vista desse fato, como o horizonte de planejamento da empresa possui um prazo geralmente inferior àquele necessário para que a PPP faça efeito, que é o problema da maior parte das empresas, haverá, sim, o risco do câmbio, no exemplo. 
Além disso, embora a PPP se mantenha para o agregado com respeito ao nível de preço de dois países, ela, geralmente, não funciona para cada uma das partes do agregado. Portanto, o argumento baseado na PPP, de que o hedge não adicionaria valor, não acaba sendo substancial e estaria destoando dos objetivos e obrigações, principalmente, de curto prazo da empresa.

b) Modigliani \& Miller

Modigliani e Miller mostraram que, num mercado perfeito, a política de financiamento de uma empresa não afeta o seu valor, já que os acionistas poderão montar a estrutura desejada ao realizar ou tomar empréstimos.

Analogamente à estrutura de capital, os acionistas poderão realizar a proteção de seus ativos através do hedge por si sós não precisando do intermédio da empresa. Assim, o hedge não adicionaria valor para o acionista.

Esse argumento seria correto a não ser por alguns pontos, dentre eles bastaria citarem-se: os acionistas não possuem a mesma informação que os administradores sobre os riscos incorridos pela empresa e os custos de transações e comissões serão menores quanto maiores forem as transações, ou seja, haveria uma economia de escala. Todos esses pontos são constatações da imperfeição do mercado e, assim, atingem um dos alicerces do modelo de M\&M, o mercado perfeito.

\section{c) CAPM}

De acordo com a teoria clássica de finanças, o valor de uma empresa através da abordagem do fluxo de caixa descontado é igual ao valor presente dos fluxos de caixa esperados descontados 
a uma taxa que reflita os riscos desse fluxo de caixa. Seja $C F_{t}$ representando o fluxo de caixa líquido da empresa no instante $t$ e $i$ a taxa de desconto ajustada ao risco ao longo do período $t$. Então, o valor da empresa é determinado por:

$V=\sum_{t} \frac{E\left[C F_{t}\right]}{(1+i)^{t}}$

Observando a expressão acima, constata-se que para o hedge aumentar o valor da empresa é necessário que o seu efeito se reflita ou num aumento dos fluxos ou numa redução da taxa de desconto. Como o hedge implica num desembolso e, assim, numa diminuição dos fluxos de caixa, tem-se então, que a única forma de ele aumentar o valor da empresa, é através da redução da taxa de desconto.

O modelo-padrão usado para avaliar a taxa de desconto é o CAPM - Capital Asset Pricing Model; nele, o prêmio de risco é em função do beta. Essa medida mensura a quantidade de risco sistêmico, ou seja, aquele que não pode ser eliminado pela diversificação. De acordo com Buckley (1996, p. 179) “os riscos que são geralmente alvo de uma política de gerenciamento de exposições [...] podem ser considerados como riscos diversificáveis”, e, portanto, pela teoria das finanças corporativas, não haveria recompensa por incorrer em riscos diversificáveis, pois esses já estariam diversificados nas carteiras dos investidores.

Assim, desde que o hedge não altera nem a taxa de desconto e nem o fluxo de caixa esperado, ele não adicionaria valor à empresa. 
A linha de raciocínio por trás tanto do trabalho de M\&M e quanto do CAPM leva à conclusão de que as empresas não devem se envolver em qualquer atividade de redução de risco em que os investidores individuais possam desempenhar a seu critério.

No entanto, esse raciocínio parece não levar em consideração, por exemplo, que, ao utilizar um instrumento de proteção do preço de uma matéria-prima, uma empresa pode estabilizar os custos e, conseqüentemente, sua política de formação de preços. Isso poderia permitir que a empresa alcançasse uma vantagem competitiva no mercado. A incerteza sobre os custos, também, dificulta o planejamento, complicando a otimização de operações e processos.

Dentre alguns estudos sobre o hedge e o valor da empresa, Smithson (1999, p. 44:45) comenta que nenhum dos estudos que ele citou provê uma evidência definitiva, mas ele acredita que a maioria dos resultados tende a suportar a proposição de que o hedge aumenta o valor da empresa. Allayannis e Weston (2001, p. 273) concluíram que, numa amostra de 720 empresas entre 1990 e 1995, o uso de derivativos de moeda estrangeira aumentou o valor total da firma, em média, de 4,87\% em relação àquelas que não utilizavam esses derivativos. 


\subsection{QUANDO O HEDGE CRIA VALOR PARA A EMPRESA E SOBRE O QUE FAZER O HEDGE}

\subsubsection{Quando o hedge cria valor para a empresa}

Segundo Siegel e Siegel (1990, p. 149), os principais motivos que levariam as empresas a fazerem hedge estariam relacionados a impostos, falência e custo de desastre financeiro, assimetria informacional e outras situações que pudessem fugir do controle dos gestores e provocar uma alta volatilidade no valor futuro da empresa.

Segue um detalhamento maior dos motivos citados, além de outros que levariam as empresas a realizarem o hedge:

\section{a) Falência e Custo de Desastre Financeiro}

O custo do capital está fortemente ligado à percepção de risco do investidor. Logo, um maior risco implica num aumento do custo de capital para a empresa. O risco percebido pelo investidor é de que a empresa não honre as suas obrigações e, conseqüentemente, esteja em vias de um desastre financeiro ou de um processo de falência.

Smith e Stulz (1985, p. 396) argumentam que o hedge é um método pelo qual as empresas podem reduzir a volatilidade do seu valor futuro e, assim, diminuir a probabilidade de incorrer em custos de falência. Como o custo de falência é uma função decrescente do valor da firma, tem-se que o hedge, ao reduzir a chance da falência, deveria, portanto, aumentar o valor da empresa. Desse modo, a escolha do hedge ocorrerá com maior freqüência em firmas com maiores custos de falência ou maiores probabilidades de falência. 
Complementando essa visão, Mayers e Smith (1990, p.21) afirmam que “[...] os custos esperados de uma falência serão mais importantes para empresas com maiores volatilidades do seu fluxo de caixa”.

Os impactos de uma falência estariam no desaparecimento do crédito, na preocupação dos consumidores sobre a habilidade da companhia em prover serviços futuros e na criação de insegurança entre os funcionários. Haveria, também, o problema do investimento, pois, quando uma corporação se aproxima de um desastre financeiro, os acionistas ficam mais relutantes em prover capital adicional mesmo para projetos rentáveis, já que parte do valor adicionado iria para os credores.

Portanto, firmas com grandes dívidas e que estejam passando por dificuldades financeiras, devem fazer hedge para evitar uma possível diminuição nos ganhos, um aumento na probabilidade de incorrer em falência e, conseqüentemente, um encarecimento do custo do capital.

\section{b) Assimetria Informacional}

A teoria clássica de finanças assume que os investidores e os administradores compartilham da mesma informação. Mas, no mundo real, pode-se esperar que a administração tenha uma maior quantidade de informações. Logo, se a corporação mostrar resultados voláteis, então, os acionistas não saberão se essas flutuações serão devidas aos riscos financeiros, que poderiam ser objetos de hedge, ou se a variabilidade é causada pela incompetência dos administradores.

Sob essas circunstâncias, a administração poderia racionalmente decidir em fazer o hedge. Efeito similar é observado na política de dividendos, na qual a administração, geralmente, 
prefere dividendos estáveis ao invés de ganhos flutuantes. A idéia é que, pagando dividendos estáveis, a administração envia uma mensagem de competência e fé no futuro da companhia aos acionistas.

DeMarzo e Duffie (1995, p. 746) afirmam que o "hedge elimina o ruído sobre os lucros da firma, fazendo com que os lucros sejam um sinal mais informativo da qualidade administrativa. Assim, as percepções dos acionistas das habilidades gerenciais são mais sensíveis ao desempenho da empresa se o hedge é empreendido”. O modelo proposto por DeMarzo e Duffie (1991) sugere que acionistas de firmas com uma grande assimetria informacional obterão vários benefícios se a empresa realizar o hedge.

\section{c) Custo de Agência com Credores}

Como dito anteriormente, os credores, por terem prioridade sobre os fluxos de caixa em relação aos acionistas, farão com que esses acabem não tendo incentivos de aportar recursos para investimentos cujos retornos - pela situação de alto endividamento - serão provavelmente usados para pagamento de dívidas.

Por sua vez, os credores antecipam um conflito de interesses e incorporam seus custos nas taxas de juros. Mayers e Smith (1990) mostram que o hedge reduz a probabilidade de a empresa não cumprir suas obrigações, reduzindo, assim, a probabilidade que os investimentos sejam distorcidos e, conseqüentemente, beneficiando os acionistas pela redução da taxa de juros.

O hedge, portanto, leva a uma política de investimento mais próxima daquela que maximiza o valor da firma. Por outro lado, Géczy, Minton e Schrand (1997, p.1345) argumentam que 
empresas muito endividadas e que "estejam muito próximas da falência têm maiores incentivos para especular e adiar a resolução da incerteza”.

Já Nance, Smith e Smithson (1993, p. 270) argumentam que uma das maneiras da empresa não incorrer num custo de agência com os credores seria substituir a dívida por ações preferenciais ou por dividas conversíveis, com o intuito de reduzirem os conflitos entre os acionistas e os credores e também o custo de agência, sem assim precisar fazer hedge. Logo, os autores prevêem uma relação negativa entre o volume de ações preferenciais e a probabilidade de hedge. Géczy, Minton e Schrand (1997, p. 1329), ao contrário, argumentam que há uma relação positiva entre as ações preferenciais e a probabilidade de hedge, pois firmas com mais restrições financeiras tendem a adotar uma política de investimentos subótima. Segundo os autores, como as ações preferenciais aumentam os custos financeiros, a probabilidade de hedge, também, aumentará.

\section{d) Economias de Escala}

Géczy, Minton e Schrand (1997, p. 1325) verificaram "que empresas com as maiores economias de escala na implementação e manutenção de um programa de administração de risco são mais provável em usar os derivativos de moeda”. Confirmando essa hipótese, Mian (1996, p. 437) encontrou evidências de que existe uma maior probabilidade de que as empresas maiores realizem hedge. Segundo Mian (1996, p. 437), “esta evidência suporta a hipótese que existem economias de escala no hedge e que as considerações sobre as transações tenham mais influência nas atividades de hedge do que o custo de financiamento”. 


\section{e) Aumento da Capacidade de Endividamento}

Um outro motivo para realizar o hedge decorreria da necessidade de um aumento da capacidade da empresa em tomar dívida, visto que o hedge reduziria a volatilidade do valor da empresa e, conseqüentemente, na percepção de um menor risco da empresa pelo mercado.

Graham e Rogers (2002, p. 816) verificaram uma relação positiva entre o uso de derivativos e a capacidade de endividamento numa ampla amostra de empresas; em média, houve um aumento na razão de endividamento de $3 \%$ e os benefícios tributários capitalizados corresponderam a, aproximadamente, $1,1 \%$ do valor da empresa.

Mas um débito adicionaria valor à empresa? Sim, numa situação em que existam restrições financeiras e os mercados sejam ineficientes, e o endividamento seja a única maneira de financiar um projeto atrativo.

\section{f) Aversão ao risco dos stakeholders}

De acordo com Smith e Stulz (1985, p. 399), os administradores, funcionários, fornecedores e clientes, geralmente, são incapazes de diversificar os riscos específicos dos seus direitos sobre a empresa. Como esses stakeholders são avessos ao risco, é de se esperar que exijam uma compensação por incorrerem neles. Mas a empresa poderia mitigar esses riscos através do hedge e, assim, incorrer numa compensação menor para os seus stakeholders. Portanto, a condição para que o hedge aumente o valor da firma será quando o seu custo for menor do que a redução nas compensações dos administradores, funcionários e fornecedores mais o aumento na receita com os clientes. 


\section{g) Impostos}

Se uma empresa é taxada, através de uma tabela progressiva cujo, gráfico da alíquota do imposto em função do lucro antes do imposto assuma a forma de uma curva convexa, então, a redução da volatilidade, através do hedge do lucro tributado, reduzirá o total a ser pago de impostos.

Para isto, tome-se o exemplo de que a alíquota do imposto expressa pelo lucro antes do mesmo obedeça à curva que se encontra a seguir:

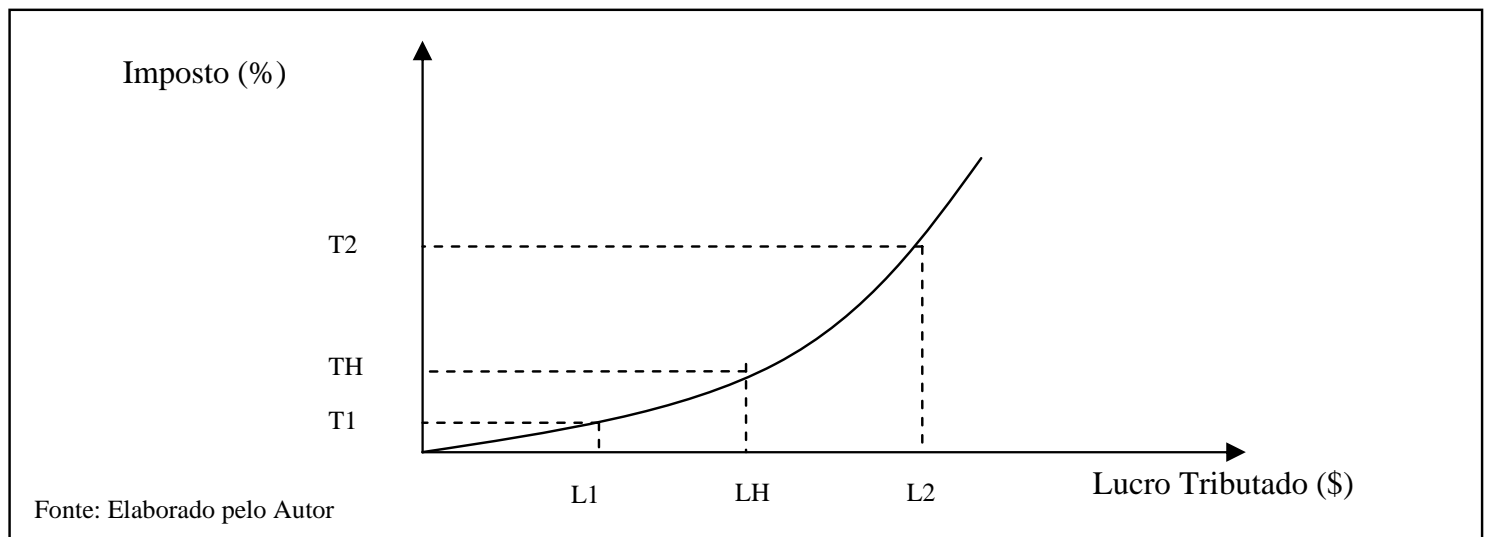

Figura 8 - Curva convexa do imposto versus lucro tributado

Para ilustrar o efeito de uma taxa de tributação progressiva, admita que existam dois cenários equiprováveis para uma empresa, num deles o lucro tributado é igual a L1 e no outro a L2. O valor esperado do lucro tributado é igual a LH. No caso de a empresa não realizar o hedge, a alíquota esperada do imposto a pagar será igual a:

$\frac{T 1+T 2}{2}$

Mas se a empresa optar pelo hedge e assegurar o lucro de LH, a nova alíquota do imposto será igual a TH. Devido à convexidade da curva, é fácil verificar que: 
$\frac{T 1+T 2}{2}>T H$

Ou seja, através do hedge, a empresa reduziria os impostos a pagar nessa situação. Portanto, quanto mais convexa for a curva, maior será o ganho tributário.

Uma outra situação em que o hedge adiciona valor à empresa é quando a firma possui benefícios fiscais que expirarão no curto prazo. Nesse aspecto, é preferível que a empresa assegure o lucro e possa usufruir a vantagem fiscal e, assim, pagar um imposto menor do que arriscar-se a perder esse beneficio, embora firmas com pouca variabilidade no resultado ganhem muito pouco devido a esse efeito.

\section{h) Oportunidades de Investimento}

Froot, Scharfstein e Stein (1993, p. 1630:1631) afirmam que o hedge auxilia a corporação a assegurar que tenha recursos suficientes para financiar as oportunidades de investimento. Esse argumento presume que as imperfeições do mercado de capital fazem com que as fontes de recurso externo sejam custosas. Conseqüentemente, um baixo fluxo de caixa forçaria a empresa a evitar investimentos rentáveis ou a aumentar o uso do financiamento externo. Ao reduzir a probabilidade de a companhia enfrentar uma escassez do fluxo de caixa, o hedge reduz a influência das fontes de financiamento externas nas decisões de investimento da empresa. Diferenças no custo do financiamento externo podem influenciar o valor do hedge, logo, quanto mais difícil é para uma companhia obter financiamento externo mais custoso será um déficit do fluxo de caixa e maior deverá ser o valor gerado pelo hedge.

Corroborando essa visão, Géczy, Minton e Schrand (1997, p. 1350) constatam que, firmas com boas oportunidades de crescimento, mas com acesso restrito tanto ao financiamento 
interno quanto ao externo, são as mais prováveis de usar derivativos de câmbio. Segundo esses autores, esse resultado é consistente com a hipótese de que o hedge pode reduzir os custos associados a um sub-investimento na presença de restrições de financiamento.

Morellec e Smith (2002), também, argumentam que, quando os administradores têm controle sobre a política de financiamento, seus incentivos para o hedge aumentam com as oportunidades de investimento da empresa. No modelo proposto por esses autores, o hedge tem dois efeitos opostos: primeiro, o hedge diminui o fluxo de caixa na empresa e estabelece restrições à política de investimento de curto prazo; segundo, o hedge diminui os custos do desastre financeiro e melhora o risco de crédito da empresa que conduz para o aumento no nível de investimento no longo prazo. Esse segundo efeito tende a dominar o primeiro quando o número de oportunidades de investimento aumenta.

A relação positiva entre as oportunidades de investimento da empresa e atividades de gerenciamento de risco é confirmada por Géczy, Minton e Schrand (1997, p.1328) ao argumentarem que “o hedge mitiga o problema do sub-investimento pela redução não apenas do custo da obtenção do capital externo, mas também a dependência do financiamento externo”. Outros autores que corroboram essa visão são entre eles: Nance, Smith e Smithson (1993) e Guay e Kothari (2003).

Um caso em que se utilizou o hedge para evitar um desinvestimento é citado por Lewent e Kearney (1990), no qual eles explicam o porquê da Merck decidir fazer hedge da sua exposição em moeda estrangeira. A Merck percebeu que as despesas de P\&D representavam uma substancial porção das despesas totais. Contudo, notaram que essas despesas "forneciam a base para o futuro crescimento“, além disso, “o sucesso da indústria farmacêutica requer um 
contínuo e longo compromisso no aumento do nível dos fundos de pesquisa”. Entretanto, os administradores da empresa descobriram que "incertezas nos ganhos causados pelas volatilidades da taxa do câmbio conduziam a uma redução no crescimento das despesas de pesquisa”. Para evitar que a volatilidade na taxa de câmbio conduzisse a um desinvestimento em $\mathrm{P} \& \mathrm{D}$, a empresa optou por implementar um programa de hedge usando opções de taxa de câmbio.

\subsubsection{Sobre o que fazer o hedge}

Uma outra questão-chave de uma política de hedge é determinar o objeto do hedge. Supor que o hedge deva ser realizado em qualquer situação e sobre qualquer ativo não parece ser razoável. Para Siegel e Siegel (1990, p. 146), numa situação extrema, “a firma que fica completamente protegida de todos os seus riscos, inclusive do próprio negócio, deverá ser remunerada a uma taxa igual a taxa livre de risco”.

Crouhy, Galai e Mark (2004, p. 548) afirmam que “em geral as empresas devem se concentrar nas áreas de atividade em que tenham vantagem competitiva, e evitar áreas em que não possam agregar valor”.

Assim, segundo Crouhy, Galai e Mark (2004, p. 550), “a alta administração deve considerar também aqueles riscos aos quais a empresa está exposta que devem ser protegidos por hedge e aqueles que a empresa deve assumir como parte de sua estratégia de negócios”.

Para Hull (2002, p.72), “as empresas [...] não possuem nenhuma habilidade ou expertise com variáveis como taxa de juros, taxa de câmbio ou preço de commodities. É mais sensato que 
elas realizem o hedge dessas variáveis. As empresas poderão focar nas suas atividades principais - nos quais presumivelmente elas possuem uma particular habilidade ou expertise”.

Fica clara a mensagem de que arriscar-se é condição necessária de qualquer negócio e o hedge somente deve ser realizado nos riscos fora do próprio negócio.

Finalmente, Securato (2000, p. 64) sintetiza a questão, sobre o que fazer o hedge, quando diz:

Discenir entre especular no seu negócio e hedgear naquilo que não é o negócio da empresa é a grande fonte de perdas com derivativos, mas não se pode mais administrar as finanças das empresas sem os derivativos sem estar hedgeado nas posições que não fazem parte do seu negócio. 


\subsection{INSTRUMENTOS DE HEDGE}

Para minimizar os efeitos de risco das empresas, os administradores recorrem, em geral, aos instrumentos derivativos que têm como função primordial proteger as operações que não estão cobertas, naturalmente, pelas operações da empresa.

Os principais instrumentos de hedge são os derivativos cujo preço depende ou deriva do preço de um outro ativo. Os derivativos são contratos ou acordos privados entre duas partes, cuja soma dos ganhos e perdas deve ser igual a zero. Para qualquer ganho feito por uma das partes, a outra parte precisa sofrer uma perda de igual magnitude.

Os principais tipos de derivativos são: o contrato a termo, o contrato futuro, o swap e as opções. A seguir, será examinado cada um deles:

\section{a) Contratos a Termo}

O contrato a termo, segundo Hull (1997, p. 1), “[...] é particularmente um derivativo simples. Ele é um acordo para comprar ou vender um ativo em certa data a certo preço. O contrato a termo é usualmente entre duas instituições financeiras ou entre uma instituição financeira e um dos seus clientes corporate. Ele não é normalmente negociado em Bolsas de Valores”, por ser um contrato privado e customizado em termos da quantidade, da data e do preço do ativo objeto. De uma forma geral, no contrato a termo, a transação é postergada até um período preestabelecido quando haverá a troca do ativo negociado por dinheiro.

\section{b) Contratos Futuros}

Segundo a Chicago Board of Trade, o contrato futuro é o compromisso legalmente exigível de entregar ou receber determinada quantidade ou qualidade de uma commodity, pelo preço 
combinado no recinto de negociações de uma Bolsa de Futuros, no momento em que o contrato é executado.

Segundo Jorion (2003. p. 117), as principais características que diferem esses instrumentos dos contratos a termo são:

- Negociação em Mercados Organizados;

- Padronização;

- $\quad$ Clearing House;

- Marcação a mercado e

- Margens.

\section{c) Swaps}

O swap é um acordo predeterminado de troca de fluxo de caixa no futuro entre duas partes. O ativo objeto poderá ser uma taxa de juros, uma taxa de câmbio, o preço de uma commodity ou qualquer outro índice.

\section{d) Opções}

Os dois tipos de opções mais comuns são: a call - opção de compra e a put - opção de venda. De acordo com Hull (1997, p. 7), “uma opção call dá ao seu dono o direito de comprar o dado ativo em certa dada por certo preço. Uma opção put dá ao seu dono o direito de vender o dado ativo em certa dada por certo preço. O preço no contrato é conhecido como preço de exercício ou preço de strike; a data do contrato é conhecida como data de vencimento, data de exercício ou maturidade”. O valor pago pela opção no ato da compra é chamado de prêmio da opção. 
Segundo Rubinstein (1999, p.32), "os estranhos nomes call e put derivam da ação que pode ser tomada pelo comprador da opção. O comprador de uma call pode requerer/chamar (call) o ativo objeto do vendedor, e o comprador de uma put pode pôr/colocar (put) o ativo objeto para o vendedor”.

Com relação à data de exercício da opção, as opções podem ser americanas ou européias. As opções americanas podem ser exercidas em data anterior ou na data de vencimento. As opções européias podem ser exercidas apenas na data de vencimento.

Denominando $S_{T}$ o preço do ativo na data $T$ e $K$, o preço de exercício da opção é possível ocorrerem três situações. Se $S_{T}$ for muito próximo de $K$, diz-se que a opção se encontra no dinheiro (at-the-money). Se $S_{T}$ é de tal forma que a opção possa ser exercida com ganho, dizse que a opção está dentro do dinheiro (in-the-money). Na última situação, em que o exercício da opção ocasiona uma perda, diz-se que a opção está fora do dinheiro (out-of-money).

Hull (1997, p. 167) apresenta uma importante relação entre o prêmio de uma call (c) e o prêmio de uma put ( $p$ ) de mesmo período de vencimento $(T)$ e mesmo preço de exercício $(K)$.

Para obter essa relação, é só verificar que uma carteira formada com uma call e uma quantia de dinheiro igual a $K e^{-r T}$, em que $r$ é a taxa livre de risco, terá o mesmo valor hoje de uma outra carteira formada por uma put com uma unidade do ativo objeto $\left(S_{0}\right)$. Tem-se assim:

$$
c+K e^{-r T}=p+S_{0}
$$


Essa relação é conhecida como paridade call-put.

Por último, é importante frisar que as principais diferenças entre as opções e os contratos futuros e a termo são:

\begin{tabular}{|l|l|}
\hline \multicolumn{1}{|c|}{ Opções } & \multicolumn{1}{|c|}{ Contratos Futuros e a Termo } \\
\hline $\begin{array}{l}\text { O detentor tem o direito de exercer a compra } \\
\text { ou a venda de um ativo objeto. }\end{array}$ & $\begin{array}{l}\text { O detentor compra ou vende um ativo } \\
\text { objeto. }\end{array}$ \\
\hline $\begin{array}{l}\text { Existe o desembolso para a aquisição de uma } \\
\text { opção (prêmio). }\end{array}$ & $\begin{array}{l}\text { Não existe o desembolso para a aquisição } \\
\text { de contratos futuros ou a termo. }\end{array}$ \\
\hline
\end{tabular}

Quadro 2 - Principais diferenças entre opções e contratos futuros e a termo 


\subsection{PRECIFICAÇÃO DE OPÇÕES}

\subsubsection{O Modelo Binomial}

Considere-se que o ativo e a call sigam um processo binomial multiplicativo. Dessa forma, em cada período de tempo, os preços podem subir ou descer com uma dada probabilidade. Logo, se o preço spot do ativo é $S_{0}$, o preço no fim do período poderá ser $S_{0} u$ com probabilidade $p$ ou $S_{0} d$ com probabilidade $(1-p)$. Essa situação está representada abaixo:

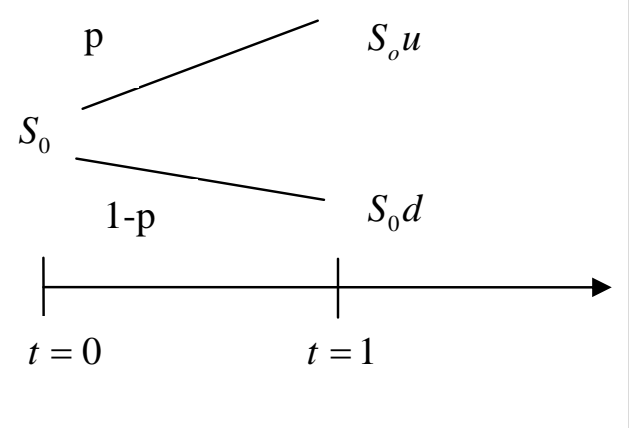

Figura 9 - Árvore binomial de dois estados para o ativo S

Obtido pela árvore binomial o preço do ativo na data $t=1$, pode-se estabelecer o preço da call nessa data para um valor de exercício $K$, dado por:

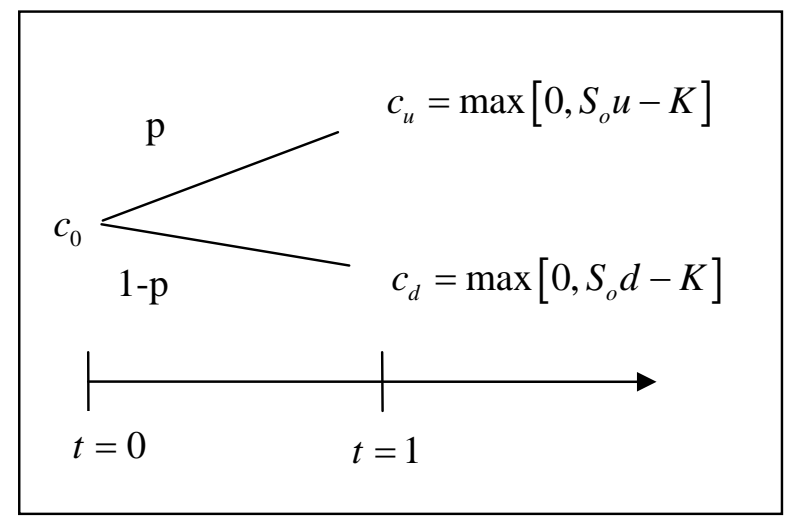

Figura 10 - Árvore binomial de dois estados para a opção C

Utilizando a abordagem probabilística neutra ao risco, vale a relação: 


$$
\begin{aligned}
& S_{0}\left(1+i_{f}\right)=p u S_{0}+(1-p) d S_{0} \\
& p=\frac{\left(1+i_{f}\right)-d}{u-d}
\end{aligned}
$$

Que permitirá voltar para a data $t=0$ a uma taxa livre de risco $i_{f}$ e obter o preço $c_{0}$ da call dado por:

$$
c_{0}=\frac{c_{u} p+c_{d}(1-p)}{\left(1+i_{f}\right)}
$$

sendo $p$ a probabilidade neutra ao risco.

A construção da árvore binomial relativa ao preço do ativo pode ser estendida até o período que se desejar $t=n$. Imaginando que ao final de $n$ a opção tenha acabado dentro do dinheiro para $\underline{a}$ subidas, tem se a fórmula binomial de precificação de opções dado por:

$c_{0}=S_{0} \Phi[a ; n ; q]-X\left(1+i_{f}\right)^{-n} \Phi[a ; n ; p]$

Sendo: $\Phi[a ; n ; q] \underline{\underline{\underline{n o t}}} \sum_{j=a}^{n}\left(\begin{array}{c}n \\ j\end{array}\right)(q)^{j}(1-q)^{n-j}$ e $\Phi[a ; n ; p] \underline{\underline{n o t}} \sum_{j=a}^{n}\left(\begin{array}{c}n \\ j\end{array}\right)(p)^{j}(1-p)^{n-j}$

A dedução completa, da fórmula acima, pode ser vista em Cox, Rubinstein e Ross (1979, p. 232-239) ou no apêndice. 


\subsubsection{O Modelo de Black-Scholes (B\&S)}

Anteriormente, foi mostrada a fórmula de precificação de opções utilizando a abordagem binomial para um número grande de período. Mas quando se faz $n$ tender ao infinito, tem-se:

$\Phi[a ; n ; q] \rightarrow N\left(d_{1}\right) \quad$ e $\quad \Phi[a ; n ; p] \rightarrow N\left(d_{2}\right)$

E, assim, obtém-se o modelo de B\&S para uma call, expresso por:

$$
c_{0}=S_{0} N\left(d_{1}\right)-K e^{-r T} N\left(d_{2}\right) \text { ou } c_{0}=e^{-r T}\left(S_{0} e^{r T} N\left(d_{1}\right)-K N\left(d_{2}\right)\right)
$$

Sendo:

$d_{1}=\frac{\ln \left(\frac{S_{0}}{K}\right)+\left(r+\frac{\sigma^{2}}{2}\right) T}{\sigma \sqrt{T}}$ e $d_{2}=d_{1}-\sigma \sqrt{T}$

$N($.$) é a distribuição normal padronizada;$

$S_{0}$ é o preço do ativo em 0 ;

$K$ é o preço de exercício;

$r$ é a taxa livre de risco;

$T$ é o período de hedge ou o tempo para o vencimento da opção e

$\sigma$ é a volatilidade do preço do ativo.

De acordo com Black e Scholes (1973, p. 640), a validade da fórmula depende de alguns pressupostos, entre eles:

a) A taxa livre de risco é constante e igual para todas as maturidades;

b) O preço do ativo segue um caminho aleatório contínuo no tempo e a distribuição dos possíveis preços do ativo no fim de um dado intervalo de tempo é log-normal e a variância da taxa de retorno do papel é constante;

c) O papel não paga dividendos e nem outras distribuições;

d) A opção precificada é do tipo Européia; 
e) Não existem custos de transação na compra ou na venda, seja de ações, seja de opções;

f) É possível tomar qualquer valor referente a um pedaço do preço do ativo, seja para comprá-lo, seja para mantê-lo, na taxa livre de risco;

g) Não há penalidades para a venda a descoberto. Um vendedor que não possua o ativo, simplesmente aceitaria o preço acordado com o comprador e, aceitaria realizar a entrega do ativo numa certa data ao preço previamente acordado.

Apesar de ser muito difícil observar todas as condições anteriormente necessárias no mundo real, segundo Hull (2002, p. 44), “o que nós precisamos é que elas sejam verdadeiras - ou pelo menos próximo da verdade - para alguns participantes chaves tais como os grandes bancos de investimento”. Corroborando, Black (1989, p. 68) afirma que desde que muitas premissas do modelo de B\&S não espelham perfeitamente o mundo real, a fórmula então está errada. Apesar disso, não existe nenhum outro modelo ou fórmula que forneça um melhor resultado numa grande gama de circunstância do que o B\&S.

Para obter o valor do prêmio de uma put, basta utilizar a fórmula da paridade call-put e a propriedade da distribuição normal de que $N(x)=1-N(-x)$. Dessa forma, chega-se à seguinte fórmula para a put:

$$
p_{0}=K e^{-r T} N\left(-d_{2}\right)-S_{0} N\left(-d_{1}\right)
$$

Logo, o modelo de B\&S não é uma alternativa ao modelo binomial, mas, ao invés disso, é um caso particular desse último, mediante as suposições de que o "preço do ativo se ajusta rapidamente evitando arbitragens, que o preço do ativo muda continuamente e sem saltos e que os retornos do ativo seguem uma distribuição log-normal” Kolb (1995, p. 162). Já que, 
segundo Damodaran (2003, p. 448), quando o período de tempo do modelo binomial tende a zero, a distribuição de probabilidades pode assumir uma de duas formas. Isso dependerá do tamanho da variação dos preços, para grandes variações ou saltos, a distribuição assumirá a forma de uma distribuição de Poison, enquanto para pequenas variações do preço, a distribuição será a normal.

Mediante as suposições anteriores e as outras citadas, o modelo binomial convergirá para o modelo de Black\&Scholes para um número de períodos tendendo ao infinito.

Segundo Rubinstein (1999, p. 275), “em geral, o valor de Black-Scholes é a diferença entre o valor presente dos benefícios do exercício menos o valor presente do custo do exercício, cada um ponderado por um número”.

Segundo Hull (1997, p. 241):

A expressão $N\left(d_{2}\right)$ é a probabilidade de que a opção seja exercida no mundo neutro ao risco, logo $K N\left(d_{2}\right)$ é o preço de exercício vezes a probabilidade que o preço de exercício seja pago. A expressão $S_{0} N\left(d_{1}\right) e^{r T}$ é o valor esperado de uma variável que iguala $S_{T}$ se $S_{T}>K$ e zero caso contrário, no mundo neutro ao risco.

Um aspecto importante entre o modelo binomial e o B\&S é referente ao caminho. A árvore binomial representa todos os possíveis valores que um ativo pode assumir, juntamente com os caminhos que conduzem a esses valores. Se o valor da opção depender apenas dos possíveis valores finais sem levar em conta o caminho para atingir esses valores, é dito que essa opção se caracteriza por ser independente do caminho (path-independent). 


\subsubsection{O Modelo de Black-Scholes (B\&S) para opções de ações que paguem dividendos periódicos}

Ao lidar com ativos que paguem, periodicamente, uma remuneração, por exemplo, os dividendos recebidos das ações, o modelo de B\&S, apresentado anteriormente, sofre algumas modificações para se adequar a essa característica do ativo.

O pagamento do dividendo ocasiona uma queda no preço do papel. Assim, o pagamento de um dividendo a uma taxa $q$ faz com que a taxa de crescimento do preço do papel seja menor, ou seja, se com o pagamento de um dividendo igual a $q$, o ativo cresceria de $S_{0}$ no tempo, zero para $S_{t}$ no tempo $T$, então, na ausência do dividendo o crescimento de $S_{0}$ no tempo zero corresponderá a $S_{T} e^{q T}$ no tempo $T$, isto é, o mesmo que o crescimento de $S_{0} e^{-q T}$ no tempo zero corresponderá a $S_{T}$ no tempo $T$.

Pelo raciocínio mostrado, tem-se que os dois raciocínios abaixo são equivalentes:

a) O preço inicial da ação é de $S_{0}$ e ela paga dividendos a uma taxa constante $q$;

b) O preço inicial da ação é de $S_{0} e^{-q T}$ e ela não paga dividendos.

Utilizando esse último fato como artifício na fórmula de B\&S, tem-se que o modelo de precificação de ações que paguem dividendos é:

$$
c_{0}=S_{0} e^{-q T} N\left(d_{1}\right)-K e^{-r T} N\left(d_{2}\right)
$$

Sendo:

$$
d_{1}=\frac{\ln \left(\frac{S_{0} e^{-q T}}{K}\right)+\left(r+\frac{\sigma^{2}}{2}\right) T}{\sigma \sqrt{T}}=\frac{\ln \left(\frac{S_{0}}{K}\right)+\left(r-q+\frac{\sigma^{2}}{2}\right) T}{\sigma \sqrt{T}} \text { e } \quad d_{2}=d_{1}-\sigma \sqrt{T}
$$


$N($.$) é a distribuição normal padronizada;$

$S_{0}$ é o preço do ativo em 0 ;

$K$ é o preço de exercício;

$r$ é a taxa livre de risco;

$T$ é o período de hedge ou o tempo para o vencimento da opção;

$\sigma$ é a volatilidade do preço do ativo e

$q$ é a taxa do dividendo pago. 


\subsubsection{O Modelo de Black-Scholes (B\&S) para opções de moeda ou modelo de Garman e Kohlhagen (1983)}

Como afirma Hull (2002, p. 277), “uma moeda estrangeira é análogo a uma ação que paga um dividendo conhecido [...] o proprietário da moeda estrangeira recebe um dividendo igual a taxa livre de risco, $r_{f}$, na moeda estrangeira”.

Como o processo estocástico que rege o comportamento da moeda estrangeira é o mesmo que para uma ação que pague dividendos iguais à taxa livre de risco do país emissor da moeda, a fórmula apresentada anteriormente para o caso da opção de uma ação que pague dividendos serão as mesmas ao substituir $q$ por $r_{f}$. Assim, o preço de uma call européia para uma opção de moeda será dado por:

$c_{0}=S_{0} e^{-r_{f} T} N\left(d_{1}\right)-K e^{-r T} N\left(d_{2}\right)$

Sendo:

$d_{1}=\frac{\ln \left(\frac{S_{0} e^{-r_{f} T}}{K}\right)+\left(r+\frac{\sigma^{2}}{2}\right) T}{\sigma \sqrt{T}}=\frac{\ln \left(\frac{S_{0}}{K}\right)+\left(r-r_{f}+\frac{\sigma^{2}}{2}\right) T}{\sigma \sqrt{T}}$ e $\quad d_{2}=d_{1}-\sigma \sqrt{T}$

$N($.$) é a distribuição normal padronizada;$

$S_{0}$ é o preço do ativo em 0 ;

$K$ é o preço de exercício;

$r$ é a taxa livre de risco doméstica;

$T$ é o período de hedge ou o tempo para o vencimento da opção ;

$\sigma$ é a volatilidade do preço do ativo e

$r_{f}$ é a taxa livre de risco do pais emissor da moeda. 


\section{CAPÍTULO 4 - A POLÍTICA DE HEDGE E OS NEGÓCIOS DA EMPRESA}

\subsection{ENTENDENDO A EMPRESA}

Em qualquer dicionário, o termo negócio está ligado a comercializar ou transacionar, o que dá a idéia de compra e venda. Assim, pode-se entender que a empresa em cada um dos estágios da sua cadeia produtiva estará comprando e vendendo ativos ou passivos e da compra à venda haverá uma transformação, um processamento. Como representado a seguir:

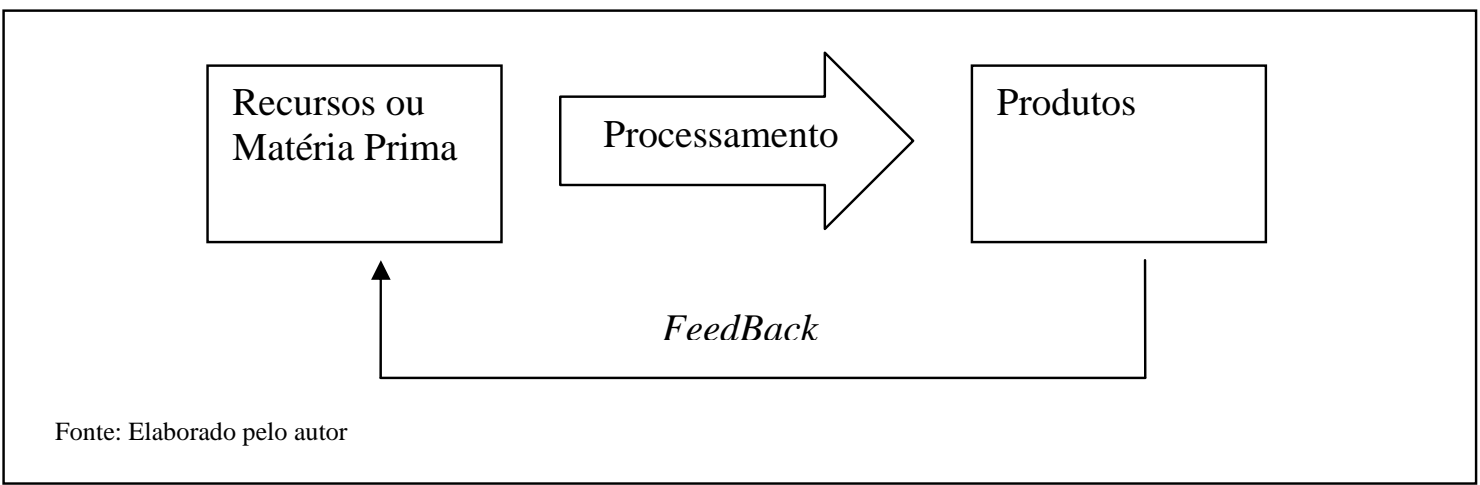

Figura 11 - Componentes do ciclo produtivo

Ou seja, de acordo com Catelli (1999, p. 39), “a empresa pode ser visualizada como um processo de transformação de recursos (materiais, humanos, financeiros, tecnológicos etc.) em produtos e serviços, composto de diversos processos menores, interdependentes, que são as atividades”. Dessa forma, as atividades da empresa podem estar ou voltadas para os clientes externos, consumidores finais, ou para atender as necessidades internas. Assim, pode-se visualizar a empresa como um conjunto de atividades. Essas idéias estão apresentadas na figura a seguir: 


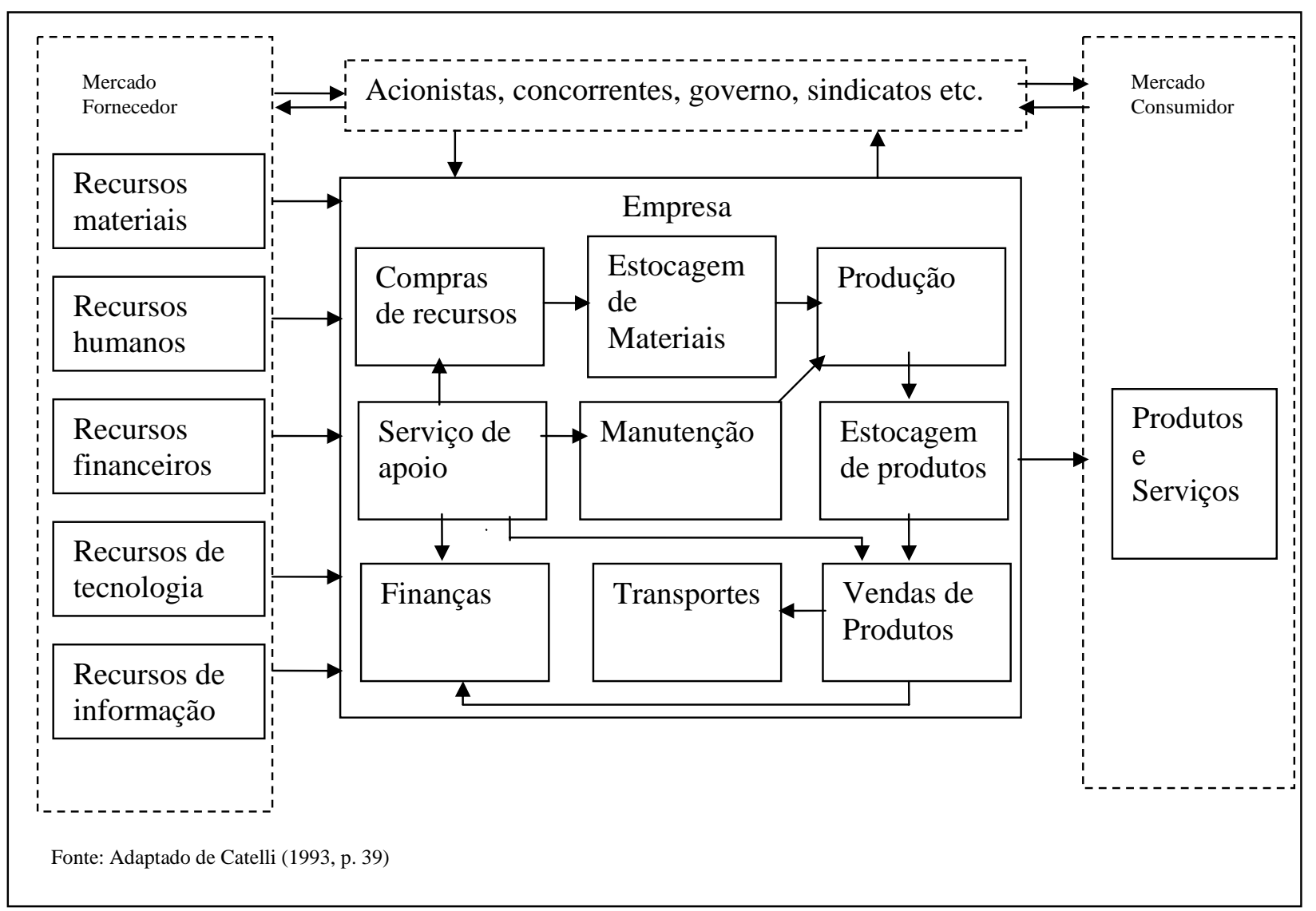

Figura 12 - Visão sistêmica da empresa

De acordo com a figura acima, tem-se que as atividades da empresa compreenderiam entre outras: compras de recursos, estocagem de materiais, produção, transportes e assim por diante. Influindo sobre a empresa estariam os seus stakeholders, a escassez dos recursos tecnológicos, financeiros, humanos, entre outros, adicionado o mercado consumidor acompanhado das suas flutuações de demanda por produtos e serviços.

É importante observar que os insumos externos de uma empresa não se restringem à matériaprima, mas a uma série de fatores que viabilizarão a produção, entre eles os recursos humanos, os recursos financeiros ou as operações de financiamento, os recursos tecnológicos e as informações utilizadas para otimização do processo produtivo e do nível ótimo de produção e estoque. Considerando a empresa como um conjunto de atividades, os produtos ou 
serviços de uma atividade servirão como insumos para uma outra, por exemplo, os produtos e serviços do negócio: estocagem de materiais servirá como insumo do negócio produção.

Corroborando, Comini (2003, p. 77) afirma que “a visão sistêmica da empresa pressupõe a interação entre as diversas áreas de responsabilidade através de transações, pelas quais as entradas de uma área são as saídas de outras ou do conjunto do sistema”.

Sob esse enfoque, as atividades internas de uma empresa, embora direcionadas ao consumidor final, acabam concorrendo, também, com outras similares no mercado. Dessa forma, não basta a empresa desenvolver a expertise, a competitividade em relação aos produtos e serviços finais, mas também às suas atividades internas, pois, caso contrário, se torna mais interessante para a empresa buscar atividade similar no mercado, incorrendo, assim, por exemplo, numa terceirização.

Conforme Catelli (1999, p. 46)

Todas as atividades mantidas internamente devem ser competitivas, contribuindo favoravelmente para os resultados globais da empresa. Caso contrário, não se justifica mantê-las no ambiente interno da empresa, tendo em vista a existência de alternativas de mercado mais interessantes para a obtenção dos produtos gerados por essas atividades.

Partindo dessa lógica, segundo Alves (1998, 40), “pode-se definir os centros de responsabilidade, centro de custo, centro de resultado, centro de investimento - que respondem pelas atividades, eventos e transações. Isso possibilita a análise do resultado por entidade”. Assim, segundo Santos (1995, p. 285), “cada área de responsabilidade possui um gestor empreendedor, dono, do seu negócio, responsável pela consecução de resultados econômicos planejados”. 
De acordo com Comini (2003, p. 76), ao perceber cada área de responsabilidade como uma unidade empresarial dentro da empresa, caberá “aos donos de área a gestão operacional, financeira, econômica e patrimonial sob sua responsabilidade”.

Portanto, a empresa pode ser vista como um conjunto de negócios interdependentes e ao mesmo tempo relativamente autônomos na sua forma de gestão. Fica clara a importância de cada parte no todo e que um risco, que não seja devidamente administrado em uma unidade de negócio, se tornará parte numa outra e, assim sucessivamente, até que a empresa se colapse. Logo, perseguir uma maior eficácia e eficiência de gestão em cada um dos negócios da empresa implicará, também, na gestão do risco das várias atividades, ou unidades de negócio, que deverá contribuir, igualmente, com uma maior rentabilidade da empresa. 


\subsection{A POLÍTICA DA GESTÃo DE RISCO}

\subsubsection{O que é uma política}

Do exposto, da forma como foi considerada a empresa pode-se entender que ela estará sujeita a vários fatores de risco, alguns fazendo parte do negócio e outros não. A primeira questão que surge é relativa à política de gestão de risco que deve indicar o que será considerado como risco, o que será protegido, em que proporção e quais os instrumentos e estratégias a serem utilizados.

Será examinada, inicialmente, o que se entende por política, dentro do contexto e como implementá-la.

Conforme Bethlen (1981, p. 1),

Numa pesquisa realizada nos EUA pela American Management Association, em 1962, após serem consultadas mais de 200 empresas, surgiram mais de 10 definições diferentes para policy, tais como:

Interesse amplo, direção ou filosofia.

Declaração dos princípios e objetivos da empresa.

Objetivos a longo prazo com repercussão sobre o planejamento geral da empresa.

Metas corporativas (corporate goals) ou linhas de orientação, de modo amplo.

Guias para pensamento e ação.

Guias de conduta estáveis e a longo prazo estabelecidas para dirigir a tomada de decisões.

Proposições amplas que possam servir de base às orientações (diretivas).

Padrões gerais que não sejam alterados frequentemente.

Instruções de funcionamento normal (standard practice).

Procedimentos (procedures) e normas práticas (practices).

No vocabulário de Administração, política é, também, amplamente usada, em vários sentidos.

Em manuais de organização e procedimentos, para denotar reações específicas tem-se, por exemplo, política de pagamento de horas extras de trabalho, política de reembolso por despesas com educação, política de depreciação total de inventário. 
Assim, sempre que eventos contingênciais são identificados é importante ter-se uma linha de condução das ações diante desses eventos. Conforme Ansoff apud Bethlem (1981, p. 7)

Um procedimento melhor e mais econômico é prescrever com antecipação a resposta a ser dada sempre que ocorrer uma contingência específica. Isto é feito por intermédio de uma definição por escrito da política apropriada e dos procedimentos para sua implementação. Desde que a decisão empresarial é desta forma tomada antes do evento, uma regra de comportamento pode ser imposta nos níveis mais baixos de supervisão. Assim sendo, são realizadas economias de gerência e é assegurada consistência na ação.

Segundo Chiavenato (1999, p. 173), uma política é constituída por:

[...] regras estabelecidas para governar funções e assegurar que elas sejam desempenhadas de acordo com os objetivos desejados. Constituem orientação administrativa para impedir que empregados desempenhem funções indesejáveis ou ponham em risco o sucesso de funções especificas. Assim, políticas são guias para a ação. Servem para prover respostas às questões ou aos problemas que podem ocorrer com certa freqüência, fazendo com que os subordinados procurem, desnecessariamente, seus supervisores para esclarecimento ou solução de caso.

Muitas vezes, as políticas não precisam ser formalizadas em documentos e nem por isso deixam de estar presentes nas práticas do dia-a-dia por serem um reflexo da filosofia da empresa.

Segundo Flippo (1975, p. 28:29), as características que as políticas precisam possuir para serem efetivas são: flexibilidade, estabilidade, consistência, clareza e aplicação geral.

De maneira geral, os autores parecem ser unânimes em afirmar que as políticas devem surgir a partir dos objetivos definidos para cada organização e possuir uma coerência interna. 


\subsection{PRINCÍPIOS DE UMA POLÍTICA DE HEDGE}

De acordo com a principal associação da indústria mundial de derivativos, a Futures Industry Association, a caracterização básica de uma política de hedge requer apenas quatro fatores:

- Identificação de riscos;

- Decisão do objeto do hedge;

- Avaliação dos instrumentos alternativos de hedge e de suas características;

- Decisão de quanto fazer em hedge.

A seguir será tratado cada um dos tópicos mencionados.

i) Identificação de riscos

A identificação de riscos implica entender como os lucros mudam com a oscilação dos fatores influenciadores das posições de risco; é procurar identificar quais são os fatores que não fazem parte do negócio e, conseqüentemente, precisem ser objetos de hedge.

Segundo Crouhy, Galai e Mark (2004, p. 549), o primeiro passo para o gerenciamento do risco é que a empresa tenha, claramente, os seus objetivos em termos de risco e retorno. Sem metas claras e totalmente analisadas e aceitas pela diretoria, a gerência corre o risco de se envolver em atividades irregulares e onerosas para se proteger, através do hedge, contra um conjunto arbitrário de riscos, sem qualquer benefício óbvio para ela e seus proprietários.

Para Adams (2000, p. 7), quando se estabelece uma política de hedge, é necessário avaliar o apetite dos acionistas e outros stakeholders pela volatilidade, considerando que alguns tipos de riscos farão diferenças e que outros não. Como exemplo: uma companhia aérea pode fazer hedge dos custos do combustível por um período com a intenção de proteger o preço dos seus bilhetes. Em contrapartida, ela pode não se preocupar com a proteção da taxa de câmbio 
necessária para que em cinco anos possa trocar os seus aviões, o que lhe pode ser fatal. Logo, uma cuidadosa avaliação dos riscos reais é requerida na formação de qualquer política de hedge, em que a primeira questão a ser colocada é: a empresa deve lançar mão do hedge para se proteger contra esse tipo de risco?

Ainda segundo Adams (2000, p.7), "se os riscos enfrentados pela companhia são claros e transparentes para os investidores, então existe uma menor necessidade do hedge. Se os riscos são complexos, e não são expostos, então a companhia tem uma grande necessidade de os proteger”.

Outro importante fator que deve ser esclarecido numa política de hedge é o prazo para quaisquer dos objetivos estabelecidos para a gerência. O hedge deve ser planejado até o final do trimestre, ou até o final do ano contábil? Deve ser fixado para os próximos dois anos? Deve-se notar que o hedge de uma transação futura esperada com um contrato de opção a longo prazo ou de futuros tem implicações contábeis e tributárias.

Assim, os objetivos devem ser estabelecidos em forma de diretrizes claras e executáveis. Além disso, os critérios para verificação da realização dos objetivos devem estar colocados com antecedência. Crouhy, Galai e Mark (2004, p. 551) sugerem que "talvez faça sentido deixar claro certos limites de risco, isto é, permitir que a gerência opere dentro de uma determinada zona de preços e taxas, e seja exposta ao risco dentro dessa zona, não permitindo exposição ao risco além desses limites”. 


\section{ii) Decisão do objeto do hedge}

Depois que os objetivos forem estabelecidos e a natureza geral dos riscos a ser gerenciados for definida, é necessário procurar associações dos riscos mapeados em relação aos ativos ou passivos da empresa.

O mesmo tipo de mapeamento pode ser aplicado a outros fatores e posições de risco, começando com o risco da atividade da empresa, antes de chegar aos seus riscos de mercado e crédito. Devem ser identificados, também, elementos de risco operacional.

A decisão do objeto de hedge passa, também, por uma avaliação do binômio envolvendo o custo da operação e os possíveis resultados gerados pela variação do fator de risco, pois, muitas vezes, não se podendo fazer hedge de todas as posições de risco, torna-se necessário realizar a escolha daquelas que auxiliem a empresa a atingir seus objetivos.

iii) Avaliação dos instrumentos alternativos de hedge e de suas características Após o mapeamento dos riscos e da adequação de quanto hedge realizar em função de um orçamento prévio, procuram-se os instrumentos relevantes para o gerenciamento de risco, pois diferentes instrumentos de hedge (opções, futuros e outros) possuem características distintas, tais como: tipos diferentes de proteção, custos esperados distintos, diferentes formas de contabilização e controle. Alguns dos instrumentos podem ser criados em nível operacional, o que pode ser entendido como hedge natural. A gerência deve avaliar cada atividade que possa ser segurada e tomar uma decisão com base nos custos e benefícios. A empresa pode decidir fazer um seguro total contra alguns riscos, um seguro parcial para outros e abster-se de fazer seguro para outros riscos. 
Durante a avaliação de estratégias de hedge assim como dos instrumentos para implementá-la, deve-se, também, considerar os custos que segundo Géczy, Minton e Schrand (1997, p. 1325)

[...] têm um papel principal na decisão da empresa no uso de derivativos e na estratégia adotada [...] os dois maiores componentes desse custo são: aqueles associados com a inicialização e manutenção do programa de gerenciamento do risco e aqueles associados com a escolha de um dado instrumento derivativo. Se os custos são muito altos, a firma não usará derivativos. Mas se eles forem baixos, eles poderão ainda influenciar a escolha dentre os vários instrumentos.

Dentre alguns dos instrumentos de que a empresa pode lançar mão no seu programa de hedge, estão as opções, os contratos a termo, os contratos futuros, swaps e outros derivativos customizados. Brown e Toft (2002, p. 1286), a partir do modelo de uma firma que enfrenta riscos decorrentes das incertezas do preço e da quantidade produzida, concluem que

[...] firmas podem se beneficiar mais de payoffs não lineares (opções) quando a correlação entre o preço e a quantidade é negativa e quando o risco associado a quantidade é grande. Se a correlação entre o preço e quantidade é desprezível, contratos a termo são instrumentos de hedge muito eficientes. Quando a correlação é positiva, derivativos exóticos oferecem um ganho adicional sobre opções e contratos a termo isolados e esses ganhos aumentam quando maior for o risco associado a quantidade e menor o risco associado ao preço.

Géczy, Minton e Schrand (1997, p. 1325) verificaram que a fonte de exposição não só afeta a escolha do uso desses derivativos, mas também na escolha entre os tipos diferentes de instrumentos. Por exemplo, empresas com exposição em moedas estrangeiras que foram resultados de operações estrangeiras ou importações estarão mais inclinadas em utilizar apenas contratos a termo, ou contratos a termo em combinação com futuros ou opções, do que swaps. Essa conclusão é consistente com a noção de que contratos a termo e opções provêem um método relativamente barato para os payofffs de transações freqüentes e incertas. 
Portanto, o gestor deverá avaliar todas as informações corporativas, dados de mercado, ferramentas e modelos relevantes. A empresa precisará selecionar modelos de precificação e hedge que auxiliem na formação da sua estratégia.

Em relação a estratégias adotadas pela empresa poderão estar: a estática e a dinâmica. Em uma estratégia estática, um instrumento de hedge é adquirido em relação a uma posição de risco e mantido enquanto tal posição existir. Já as estratégias dinâmicas envolvem uma série contínua de negociações utilizadas para a calibragem da combinação entre a exposição e a posição do derivativo. A estratégia dinâmica exige que o gestor ajuste a posição das opções diária ou semanalmente, aumentando ou reduzindo as quantidades de opções, e possivelmente mudando para outras.

É importante salientar que, durante a construção da estratégia, se leva em consideração o aspecto tributário, pois diferentes instrumentos derivativos, com diferentes prazos de vencimento, podem fazer com que a empresa incorra em obrigações tributárias muito diferentes, além disso, o tratamento tributário, também, difere de país para país.

iv) Decisão de quanto fazer em hedge

A idéia de quanto se deve fazer de hedge de uma posição em risco coberta pela empresa tem uma resposta clara: fazer hedge de 100\% da posição em risco. Essa resposta está ligada com uma outra questão que é a de quando fazer o hedge, cuja resposta, também, é clara: na abertura da posição em risco. Assim, quando a empresa abre uma posição em risco de imediato, deve-se fazer o hedge 100\% dessa posição; o que responde ao quanto e quando fazer o hedge. 
No entanto, as despesas inerentes ao hedge, muitas vezes, inviabilizam o hedge. Daí passa a fazer parte da política de hedge da empresa a questão relativa ao quanto fazer de hedge de imediato. Observe-se, dessa forma, que uma das principais atribuições da Política de Hedge é estabelecer os critérios para a determinação dessa questão.

É importante notar que o fato de fazer o hedge de apenas um percentual da posição de risco aberta implica na aceitação do risco do percentual complementar obrigando a empresa a manter uma expertise em relação a esse novo tipo de risco que será assumido.

A forma de tratamento dessa questão passa por exames de modelos que possam auxiliar no estabelecimento da política de hedge em relação ao quanto se deve fazer de hedge; o que será visto nos capítulos seguintes.

Por último, a política deve ser avaliada periodicamente, baseando-se no nível de realização das metas gerais e não no lucro ou na perda das transações do hedge. Assim, pode-se optar por mudar ou não a política de hedge atual. A mudança deve estar pautada em uma análise completa e deve ser compatível com as demais atividades da empresa. 


\section{CAPÍTULO 5 - METODOLOGIA PARA ESTABELECIMENTO DE POLÍTICA DE HEDGE NAS EMPRESAS EM FUNÇÃO DO PREÇO DE EXERCÍCIO DA OPÇÃO DE COMPRA}

\subsection{INTRODUÇÃO AO MODELO PARA A POLÍTICA DE HEDGE}

Para iniciar a montagem do modelo proposto, considere, inicialmente, uma instituição nãofinanceira que precise contrair uma dívida indexada a uma moeda para investimento no negócio. Esses recursos ela os aplicará no próprio negócio para, ao final, poder auferir o lucro referente ao seu negócio e também o montante necessário para quitar a dívida. Para tornar mais fácil a compreensão do modelo, primeiramente será considerada uma situação específica para que, no próximo passo, possa ser realizada uma generalização.

Considere uma empresa que na data $t=0$ contraia uma dívida de US\$ 1 ao custo de captação de $10 \%$ a.a. com um prazo de vencimento igual a 1 ano e como ela tem as suas operações no Brasil precisará converter o empréstimo em dólar para reais. Admita que a cotação no instante $\mathrm{T}=0$ seja de R 2 /US\$1 e que o custo médio de oportunidade da empresa em relação aos seus investimentos seja igual $I_{a}=20 \%$ a.a e que a taxa livre de risco que vigora no período seja $I_{f}$ = $18 \%$ a.a. Admitindo que a cotação passe para R \$5/1US\$, tem-se que a situação descrita se encontra representada abaixo:

\begin{tabular}{|c|c|c|}
\hline & $\mathrm{T}=0$ & $\mathrm{~T}=1$ \\
\hline Passivo Contraído & US\$ 1 & $1 * 1,1=\mathrm{US} \$ 1,1$ \\
\hline Ativo Recebido & $\mathrm{R} \$ 2$ & $2 * 1,2=\mathrm{R} \$ 2,4$ \\
\hline Tx. Troca/ Câmbio 2 & $1: 2$ & $1: 5$ \\
\hline
\end{tabular}

Tabela 2 - Exemplo da empresa que não contrata o hedge

Portanto, o resultado, nessa situação, será igual a: 
$-1,1 * 5+2,4=-5,5+2,4=\mathrm{R} \$-3,1$

Verifique que, nesta situação, a alteração da taxa de troca de um ativo pelo outro deu um resultado negativo para a empresa de $\mathrm{R} \$-3,1$ que equivale a um encarecimento da dívida em mais de 50\%! Perceba que o resultado é altamente dependente da variação da taxa de troca dos ativos.

Visando reduzir essa volatilidade do resultado, a empresa pode realizar um hedge. Assim, considerando as mesmas condições do exemplo anterior, mas que, agora, a empresa decide proteger uma fração de $h=70 \%$ da sua dívida em dólar através da compra de uma call a um preço de R\$ 0,20 com o exercício a R 2/US\$ 1. Perceba que, nessa nova situação, além da operação decorrente do negócio da empresa haverá, também, um resultado devido à operação de hedge. Admita-se, igualmente, que o valor incorrido na contratação do hedge, que nesse caso equivale à compra da opção, seja capitalizado ao custo da taxa livre de risco que no nosso exemplo é de $18 \%$ a.a. Isto pode ser melhor entendido pelo esquema abaixo:

\begin{tabular}{|c|c|c|c|}
\hline & $\begin{array}{c}\text { Resultado } \\
\text { Operacional }\end{array}$ & $\begin{array}{c}\text { Resultado do } \\
\text { Hedge }\end{array}$ & \multirow{3}{*}{$\begin{array}{l}\text { Resultado } \\
\text { Líquido }\end{array}$} \\
\hline Passivo & $-1,1 * 5=\mathrm{R} \$-5,5$ & $\begin{array}{c}0,7 *(0,20 * 1,18)= \\
\mathrm{R} \$-0,1652\end{array}$ & \\
\hline Ativo & $1,2 * 2=\mathrm{R} \$ 2,4$ & $\begin{array}{c}0,7 * \text { Máx }(0 ; 5-2)= \\
R \$+2,1\end{array}$ & \\
\hline Total & $\mathrm{R} \$-3,1$ & $\mathrm{R} \$+1,9348$ & $\mathrm{R} \$-1,1652$ \\
\hline Informações Adicionais & $\mathrm{T}=0$ & $\mathrm{~T}=1$ & \\
\hline Passivo Contraído & US\$ 1 & $1 * 1,1=\mathrm{US} \$ 1,1$ & \\
\hline Ativo Recebido & $\mathrm{R} \$ 2$ & $2 * 1,2=\mathrm{R} \$ 2,4$ & \\
\hline Tx. Troca/ Câmbio & $1: 2$ & $1: 5$ & \\
\hline
\end{tabular}

Tabela 3 - Exemplo de contratação de hedge com o exercício da call 
Ao contrair o hedge, a empresa melhorou o seu resultado final. Mas, por não ter feito $100 \%$ de hedge da sua posição em risco, ela acabou sofrendo os efeitos negativos da parcela complementar de 30\% da dívida.

Considere a mesma situação anterior, mas, agora, a taxa de troca ao invés de ser 1:5 seja de 1:1,5. Como ficará, então, o resultado da empresa ao ela ter decidido fazer hedge, inicialmente, de 70\% da sua dívida? Essa resposta pode ser obtida do esquema abaixo:

\begin{tabular}{|c|c|c|c|}
\hline & $\begin{array}{c}\text { Resultado } \\
\text { Operacional }\end{array}$ & $\begin{array}{c}\text { Resultado do } \\
\text { Hedge }\end{array}$ & \multirow{2}{*}{ Resultado } \\
Láquido & $\begin{array}{c}0,7 *(0,20 * 1,18)= \\
\mathrm{R} \$-0,1652\end{array}$ & \\
\hline Ativo & $1,2 * 2=\mathrm{R} \$ 2,4$ & $\begin{array}{c}0,7 * \mathrm{Máx}(0 ; 1,5- \\
2)=+0\end{array}$ & \\
\hline Total & $\mathrm{R} \$ 0,75$ & $\mathrm{R} \$-0,1652$ & $\mathrm{R} \$+0,5848$ \\
\hline Informações & $\mathrm{T}=0$ & $\mathrm{~T}=1$ & \\
\hline Adicionais & $\mathrm{Us} \$ 1$ & $1 * 1,1=\mathrm{Us} \$ 1,1$ & \\
\hline Passivo Contraído & $\mathrm{R} \$ 2$ & $2 * 1,2=\mathrm{R} \$ 2,4$ & \\
\hline Ativo Recebido & $1: 2$ & $1: 1,5$ & \\
\hline Tx. Troca/ Câmbio & & & \\
\hline
\end{tabular}

Tabela 4 - Exemplo de contratação de hedge sem o exercício da call

Nessa última situação, que foi desfavorável para as operações da empresa, a despesa incorrida pelo hedge foi responsável por uma queda de quase $22 \%$ do lucro operacional, ou seja, fazer hedge nessa situação acabou sendo um mau negócio.

Baseando-se nos cenários apresentados, cabe a pergunta: qual seria a estratégia razoável para lidar com o problema de quanto fazer de hedge? 


\subsection{MODELO PROPOSTO}

\subsubsection{Hipóteses Iniciais do Modelo}

O modelo a ser desenvolvido refere-se a empresas financeiras ou não-financeiras que precisem proteger suas exposições ao risco (cambial, taxa de juros e outros) através do uso de calls ou puts. Será examinado o caso da aquisição de calls para fazer o hedge. Para isso, serão estabelecidas algumas condições:

- a call escolhida será com valor de exercício tal que tenha a expectativa de que possa ser exercida no vencimento, dando acesso ao ativo para fazer o hedge;

- a empresa conta com uma limitação do valor total disponível a ser usado na compra das calls; logo, uma parcela do ativo estará sujeita a perdas;

- a empresa procura ficar o menos possível exposta ao risco, assim, ela comprará o máximo de calls;

- suponha-se a não existência de taxas, custos de transações ou quaisquer outros tipos de custo, ou seja, vale os pressupostos do mercado financeiro perfeito;

- as taxas de aplicação ou captação dos recursos, assim como, as taxas livre de risco: local (R\$) e estrangeira (US\$), são variáveis independentes;

- Os pressupostos do modelo de Black \& Scholes são respeitados no modelo proposto. 


\subsubsection{Desenvolvimento do Modelo}

\subsubsection{Caso 1 - Hedge Total}

Considere uma empresa que contraia uma dívida em moeda estrangeira de valor $S_{0}{ }^{*}$ em $t=0$ a um custo de captação igual a $I_{c}$ por período. Convertendo para a moeda local ao preço de conversão $D_{0}$, obtém-se a quantia $S_{0}=S_{0}{ }^{*} D_{0}$ na moeda local. Os recursos $S_{0}$ são aplicados na empresa à taxa do negócio igual a $I_{a}$ por período.

O resultado da operação, após $T$ períodos, no momento do pagamento da dívida será dado por:

a) Resultado da empresa antes do pagamento da dívida na data $T$, na moeda local:

$$
S_{T}=D_{0} S_{0}^{*}\left(1+I_{a}\right)^{T}
$$

b) Menos o valor a pagar da dívida em moeda estrangeira:

$$
S_{T}^{*}=S_{0}^{*}\left(1+I_{c}\right)^{T}
$$

c) Que em moeda local, sendo $D_{T}$ o preço de conversão na data $T$ :

$$
D_{T} S_{0}^{*}\left(1+I_{c}\right)^{T}
$$

Assim, o resultado final $R$ será igual a:

$$
R=D_{0} S_{0}^{*}\left(1+I_{a}\right)^{T}-D_{T} S_{0}^{*}\left(1+I_{c}\right)^{T}
$$

Considerando que, de imediato, no momento de contrair a dívida a empresa realize um hedge de toda a posição, incorrendo em um custo total, em $t=0$, igual a $C_{0}$. Esse prêmio 
corresponde à compra de $m$ calls ao preço $c_{0}$, tal que $c_{0} m=C_{0}$, sendo $D_{K}$ o valor de exercício da opção na data $T$, por unidade de moeda.

Como esse valor $C_{0}$ é retirado da empresa, então, o seu custo de oportunidade é o mesmo da empresa, ou seja, $I_{a}$.

Nessas condições, o resultado final da empresa será:

a) Não ocorrendo o exercício: isso implica que o valor da moeda na data $T$ é menor que o valor de exercício da opção, ou seja: $D_{T}<D_{K}$, logo o resultado será:

$R=D_{0} S_{0}^{*}\left(1+I_{a}\right)^{T}-C_{0}\left(1+I_{a}\right)^{T}-D_{T} S_{0}^{*}\left(1+I_{c}\right)^{T}$

b) Ocorrendo o exercício da opção: isso implica que o valor da moeda na data $T$ é maior que o valor de exercício da opção, ou seja: $D_{T}>D_{K}$ e o resultado será:

$R=D_{0} S_{0}^{*}\left(1+I_{a}\right)^{T}-C_{0}\left(1+I_{a}\right)^{T}-D_{K} S_{0}^{*}\left(1+I_{c}\right)^{T}$

O resultado final pode ser escrito, na forma geral, como:

$$
\begin{aligned}
R & =D_{0} S_{0}^{*}\left(1+I_{a}\right)^{T}-C_{0}\left(1+I_{a}\right)^{T}-D_{T} S_{0}^{*}\left(1+I_{c}\right)^{T}+\max \left(D_{T}-D_{K}, 0\right) S_{0}^{*}\left(1+I_{c}\right)^{T} \\
& =D_{0} S_{0}^{*}\left(1+I_{a}\right)^{T}-C_{0}\left(1+I_{a}\right)^{T}-S_{0}^{*}\left(1+I_{c}\right)^{T}\left[D_{T}-\max \left(D_{T}-D_{K}, 0\right)\right]
\end{aligned}
$$

Ou seja,

$$
R=D_{0} S_{0}^{*}\left(1+I_{a}\right)^{T}-C_{0}\left(1+I_{a}\right)^{T}-S_{0}^{*}\left(1+I_{c}\right)^{T} \min \left(D_{T}, D_{k}\right)
$$




\subsubsection{Caso 2 - Hedge Parcial e a Política de Hedge}

Considerando, agora, o caso de fazer o hedge parcial da exposição ao risco, em que $h$ indica o percentual a ser feito de hedge, com $0<h<1$. Para estabelecimento da proporção de hedge será utilizada a idéia de Ahn et. al. (1999, pg.362 ) na qual se fixa que a proporção de hedge $h C_{0}$ será com base em um limite orçamentário $L O$ estabelecido pela política de hedge, de forma que, na condição de hedge parcial, tem-se:

$$
h C_{0}=L O \quad \text { ou } \quad h m c_{0}=L O
$$

O resultado da operação de hedge parcial, após $T$ períodos, no momento do pagamento da dívida será dado por:

a) Resultado da empresa antes do pagamento da dívida na data $T$, na moeda local:

$$
S_{T}=D_{0} S_{0}^{*}\left(1+I_{a}\right)^{T}
$$

b) Menos o valor a pagar referente à compra de calls limitado ao limite orçamentário $L O$, sendo esse valor corrigido ao custo de oportunidade $I_{a}$ :

$$
L O\left(1+I_{a}\right)^{T}
$$

c) Menos a parcela protegida da dívida $h$, corrigida ao custo da dívida. A esse valor será aplicada a taxa de conversão de moedas que será o mínimo entre $D_{T}$ e $D_{K}$, conseqüência do exercício ou na da opção comprada:

$$
h S_{0}{ }^{*}\left(1+I_{c}\right)^{T} \min \left(D_{T}, D_{K}\right)
$$


d) Menos a parcela não protegida da dívida (1-h), corrigida ao custo da dívida. A esse valor aplicar-se-á a taxa de conversão de moedas $D_{T}$, conseqüência da impossibilidade de realizar o hedge total do passivo:

$(1-h) S_{0}^{*}\left(1+I_{c}\right)^{T} D_{T}$

Assim, o resultado final $R$ será igual a:

$R=D_{0} S_{0}^{*}\left(1+I_{a}\right)^{T}-L O\left(1+I_{a}\right)^{T}-h S_{0}^{*}\left(1+I_{c}\right)^{T} \min \left(D_{T}, D_{K}\right)-(1-h) S_{0}^{*}\left(1+I_{c}\right)^{T} D_{T}$

- Para o caso em que a empresa não exerça a opção, $D_{T}<D_{K}$, tem-se que o resultado final será:

$R=D_{0} S_{0}^{*}\left(1+I_{a}\right)^{T}-L O\left(1+I_{a}\right)^{T}-S_{0}^{*}\left(1+I_{c}\right)^{T} D_{T}$

- Para o caso em que a empresa exerça a opção, $D_{T}>D_{K}$, tem-se que o resultado será:

$R=D_{0} S_{0}^{*}\left(1+I_{a}\right)^{T}-L O\left(1+I_{a}\right)^{T}-h S_{0}^{*}\left(1+I_{c}\right)^{T} D_{K}-(1-h) S_{0}^{*}\left(1+I_{c}\right)^{T} D_{T}$

Em que a última parcela está decomposta em: $h S_{0}^{*}\left(1+I_{c}\right)^{T} D_{K}$ e $(1-h) S_{0}^{*}\left(1+I_{c}\right)^{T} D_{T}$, sendo a primeira correspondente à parcela $h$ protegida ao preço de exercício $D_{K}$ e a última à parcela (1-h) não protegida e, portanto, liquidada ao preço de troca $D_{T}$.

Com certeza, nessa situação, há uma economia devido ao hedge parcial. Essa economia provém, basicamente, por incorrer-se num custo de $h C_{o}$, com $0<h \leq 1$, menor do que um custo de $C_{o}$, que seria incorrido num hedge total, $h=1$. 
O que interessará, no modelo, é possibilitar estabelecer a política de hedge como uma relação entre:

- a proporção de hedge $h$;

- o valor de exercício do preço da moeda $D_{K}$ e

- o limite orçamentário indicado no modelo por $L O$.

\subsubsection{O Modelo para o hedge parcial adequado à política de hedge}

O resultado do hedge parcial no caso de exercício da opção, como mostrado anteriormente, é dado por:

$$
R=D_{0} S_{0}^{*}\left(1+I_{a}\right)^{T}-L O\left(1+I_{a}\right)^{T}-h S_{0}^{*}\left(1+I_{c}\right)^{T} D_{K}-(1-h) S_{0}^{*}\left(1+I_{c}\right)^{T} D_{T}
$$

Analisando o resultado final $R$ para uma unidade da dívida, que equivale a $S_{0}^{*}=1$ e, conseqüentemente, $\mathrm{m}=1$, tem-se, então, para fórmula do resultado final para uma unidade de dívida:

$$
R_{u}=D_{0}\left(1+I_{a}\right)^{T}-h c_{0}\left(1+I_{a}\right)^{T}-h\left(1+I_{c}\right)^{T} D_{K}-(1-h)\left(1+I_{c}\right)^{T} D_{T}^{*}
$$

Deseja-se maximizar $R_{u}$ com relação a $D_{K}$ e $h$, ou seja, diante de opções com diversos exercícios, qual deverá ser escolhida e a que razão ou proporção deve-se fazer o hedge para se obter o máximo $R_{u}$. Como $c_{0} h=L O_{u}$, sendo $L O_{u}$ o limite orçamentário unitário, ao substituir $h=\frac{L O_{u}}{c_{0}}$ em $R_{u}$, tem-se:

$$
\begin{aligned}
& R_{u}=D_{0}\left(1+I_{a}\right)^{T}-\frac{L O_{u}}{c_{0}} c_{0}\left(1+I_{a}\right)^{T}-\frac{L O_{u}}{c_{0}}\left(1+I_{c}\right)^{T} D_{K}-\left(1-\frac{L O_{u}}{c_{0}}\right)\left(1+I_{c}\right)^{T} D_{T} \\
& R_{u}=D_{0}\left(1+I_{a}\right)^{T}-L O_{u}\left(1+I_{a}\right)^{T}-\frac{L O_{u}}{c_{0}}\left(1+I_{c}\right)^{T} D_{K}-\left(1-\frac{L O_{u}}{c_{0}}\right)\left(1+I_{c}\right)^{T} D_{T}
\end{aligned}
$$


Logo, derivando $R_{u}$ em relação a $D_{K}$, para um dado $D_{T}$ fixado, tem-se:

$$
\begin{aligned}
& R_{u}=D_{0}\left(1+I_{a}\right)^{T}-L O_{u}\left(1+I_{a}\right)^{T}-\frac{L O_{u}}{c_{0}}\left(1+I_{c}\right)^{T} D_{K}-\left(1-\frac{L O_{u}}{c_{0}}\right)\left(1+I_{c}\right)^{T} D_{T} \\
& \frac{\partial R_{u}}{\partial D_{K}}=-\left(1+I_{c}\right)^{T} L O_{u} \frac{\partial}{\partial D_{K}}\left(\frac{D_{K}}{c_{0}}\right)+\left(1+I_{c}\right)^{T} D_{T} L O_{u} \frac{\partial}{\partial D_{K}}\left(\frac{1}{c_{0}}\right) \\
& \frac{\partial R_{u}}{\partial D_{K}}=-\left(1+I_{c}\right)^{T} L O_{u}\left[\frac{c_{0} \frac{\partial D_{K}}{\partial D_{K}}-D_{K} \frac{\partial c_{0}}{\partial D_{K}}}{c_{0}^{2}}\right]+\left(1+I_{c}\right)^{T} D_{T} L O_{u}\left[\frac{c_{0} \frac{\partial 1}{\partial D_{K}}-1 \frac{\partial c_{0}}{\partial D_{K}}}{c_{0}^{2}}\right] \\
& \frac{\partial R_{u}}{\partial D_{K}}=\frac{-\left(1+I_{c}\right)^{T} L O_{u}}{c_{0}^{2}}\left(c_{0}-D_{K} \frac{\partial c_{0}}{\partial D_{K}}+D_{T} \frac{\partial c_{0}}{\partial D_{K}}\right)
\end{aligned}
$$

Para determinar $\frac{\partial c_{0}}{\partial D_{K}}$, basta lembrar que o preço de uma call dada pela equação de Black \&

Scholes é:

$$
c_{0}=D_{0} N\left(d_{1}\right)-D_{K} e^{-r T} N\left(d_{2}\right)
$$

Sendo:

$d_{1}=\frac{\ln \left(\frac{S_{0}}{K}\right)+\left(r+\frac{\sigma^{2}}{2}\right) T}{\sigma \sqrt{T}}$ e $\quad d_{2}=d_{1}-\sigma \sqrt{T}$

$N($.$) é a distribuição normal padronizada;$

$D_{0}$ é o preço do ativo em 0 ;

$D_{K}$ é o preço de exercício;

$r$ é a taxa livre de risco;

$T$ é o período de hedge ou o tempo para o vencimento da opção e

$\sigma$ é a volatilidade do preço do ativo.

Tem-se, então, que a derivada de $c_{0}$ em relação a $D_{K}$ que será igual a: 


$$
\begin{aligned}
& \frac{\partial c_{0}}{\partial D_{K}}=D_{0} \frac{\partial N\left(d_{1}\right)}{\partial d_{1}} \frac{\partial d_{1}}{\partial D_{K}}-e^{-r t}\left(\frac{\partial D_{K}}{\partial D_{K}} N\left(d_{2}\right)+D_{K} \frac{\partial N\left(d_{2}\right)}{\partial d_{2}} \frac{\partial d_{2}}{\partial D_{K}}\right) \\
& \frac{\partial c_{0}}{\partial D_{K}}=D_{0} \frac{\partial}{\partial d_{1}}\left(\int_{-\infty}^{d_{1}} \frac{e^{-\frac{t^{2}}{2}}}{\sqrt{2 \pi}}\right) \frac{\partial}{\partial D_{K}}\left(\frac{\ln \left(\frac{D_{0}}{D_{K}}\right)+\left(r+\frac{\sigma_{D}^{2}}{2}\right) t}{\sigma_{D} \sqrt{t}}\right)+ \\
& -e^{-r t}\left(N\left(d_{2}\right)+D_{K} \frac{\partial}{\partial d_{2}}\left(\int_{-\infty}^{d_{1}} \frac{e^{-\frac{t^{2}}{2}}}{\sqrt{2 \pi}}\right) \frac{\partial}{\partial D_{K}}\left(\frac{\ln \left(\frac{D_{0}}{D_{K}}\right)+\left(r-\frac{\sigma_{D}^{2}}{2}\right) t}{\sigma_{D} \sqrt{t}}\right)\right) \\
& \frac{\partial c_{0}}{\partial D_{K}}=\left.D_{0} \frac{e^{-\frac{t^{2}}{2}}}{\sqrt{2 \pi}}\right|_{-\infty} ^{d_{1}} \frac{\partial}{\partial D_{K}}\left(\frac{\ln D_{0}-\ln D_{K}+\left(r+\frac{\sigma_{D}^{2}}{2}\right) t}{\sigma_{D} \sqrt{t}}\right)+ \\
& -e^{-r t}\left(N\left(d_{2}\right)+\left.D_{K} \frac{e^{-\frac{t^{2}}{2}}}{\sqrt{2 \pi}}\right|_{-\infty} ^{d_{2}} \frac{\partial}{\partial D_{K}}\left(\frac{\ln D_{0}-\ln D_{K}+\left(r-\frac{\sigma_{D}{ }^{2}}{2}\right) t}{\sigma_{D} \sqrt{t}}\right)\right) \\
& \frac{\partial c_{0}}{\partial D_{K}}=-D_{0} \frac{e^{-\frac{d_{1}^{2}}{2}}}{\sqrt{2 \pi}} \frac{1}{D_{K}} \frac{1}{\sigma_{D} \sqrt{t}}-e^{-r t}\left(N\left(d_{2}\right)-D_{K} \frac{e^{-\frac{d_{2}^{2}}{2}}}{\sqrt{2 \pi}} \frac{1}{D_{K}} \frac{1}{\sigma_{D} \sqrt{t}}\right) \\
& \frac{\partial c_{0}}{\partial D_{K}}=-\frac{D_{0} e^{-\frac{d_{1}^{2}}{2}}}{\sigma_{D} D_{K} \sqrt{2 t \pi}}-e^{-r t}\left(N\left(d_{2}\right)-\frac{e^{-\frac{d_{2}^{2}}{2}}}{\sigma_{D} \sqrt{2 t \pi}}\right)
\end{aligned}
$$

Logo, impondo-o a zero, para obtenção da condição de otimização, tem-se que o valor de $D_{K}$ que maximiza $R_{u}$ será: 


$$
\begin{aligned}
& \frac{-\left(1+I_{c}\right)^{T} L O_{u}}{\left(c_{0}^{*}\right)^{2}}\left(c_{0}^{*}-D_{K}^{*} \frac{\partial c_{0}}{\partial D_{K}}+D_{T} \frac{\partial c_{0}}{\partial D_{K}}\right)=0 \\
& c_{0}^{*}-D_{K} \frac{\partial c_{0}}{\partial D_{K}}+D_{T} \frac{\partial c_{0}}{\partial D_{K}}=0 \\
& c_{0}^{*}=\frac{\partial c_{0}}{\partial D_{K}}\left(D_{K}-D_{T}\right)
\end{aligned}
$$

Substituindo $\frac{\partial c_{0}}{\partial D_{K}}$ na expressão acima, tem-se:

$$
c_{0}^{*}=\left[-\frac{D_{0} e^{\frac{-d_{1}^{2}}{2}}}{D_{K}^{*} \sigma \sqrt{2 \pi t}}-e^{-r t} N\left(d_{2}\right)+\frac{e^{-r t} e^{\frac{-d_{2}^{2}}{2}}}{\sigma \sqrt{2 \pi t}}\right]\left[D_{K}^{*}-D_{T}\right]
$$

Seguindo o mesmo raciocínio para o caso de uma opção de compra européia de uma ação que paga um dividendo a uma taxa de $q$, tem-se que a relação de otimalidade é:

$$
c_{0}^{*}=\left[-\frac{D_{0} e^{\frac{-d_{1}^{2}}{2}}}{D_{K}^{*} \sigma \sqrt{2 \pi t}} e^{-q t}-e^{-r t} N\left(d_{2}\right)+\frac{e^{-r t} e^{\frac{-d_{2}^{2}}{2}}}{\sigma \sqrt{2 \pi t}}\right]\left[D_{K}^{*}-D_{T}\right]
$$

Semelhante a relação de otimalidade, para uma opção de compra européia de uma moeda cuja taxa livre de risco do país emissor de $r_{f}$, é:

$$
c_{0}^{*}=\left[-\frac{D_{0} e^{\frac{-d_{1}^{2}}{2}}}{D_{K}^{*} \sigma \sqrt{2 \pi t}} e^{-r_{f} t}-e^{-r t} N\left(d_{2}\right)+\frac{e^{-r t} e^{\frac{-d_{2}{ }^{2}}{2}}}{\sigma \sqrt{2 \pi t}}\right]\left[D_{K}^{*}-D_{T}\right]
$$

Observando as relações de otimalidade, constata-se a dificuldade em isolar a variável $D_{K}{ }^{*}$. Logo, $D_{K}{ }^{*}$ não admite uma forma fechada. Apesar disso não é impossível a determinação do 
valor de $D_{K}{ }^{*}$ que satisfaça a relação de otimalidade. Isso pode ser conseguido mediante a utilização de programas que resolvam a relação de otimalidade através de métodos interativos. Um ponto a observar da relação obtida é que ela não depende nem do $h$ e nem do LO. Mas determinando-se o valor de $D_{K}{ }^{*}$, determina-se, conseqüentemente, o valor de $c_{0}{ }^{*}$ que possibilitará, finalmente, a obtenção de $h^{*}$ através da relação $L O_{u}=h^{*} c_{0}\left(D_{K}{ }^{*}\right)$ equivalente a $L O_{u}=h^{*} c_{0}{ }^{*}$.

Observando as equações que otimizam o resultado, verifica-se que elas são dadas em função das seguintes variáveis:

$D_{0}$ é o preço de troca da moeda no instante $t=0$;

r é a taxa livre de risco oriundo do modelo;

$\sigma_{D}$ é a volatilidade do preço de troca da moeda em estudo;

$q$ é a taxa do dividendo pago;

$r_{f}$ é a taxa livre de risco do pais emissor da moeda;

t é o período de tempo entre a compra e o vencimento da opção;

$d_{1}$ e $d_{2}$ são dependentes do valor de $D_{K}{ }^{*}$ obtido;

$D_{K}{ }^{*}$ é o valor ótimo de exercício que maximiza o resultado;

$c_{0}^{*}$ é o valor do prêmio obtido pela fórmula de B\&S;

$D_{T}$ é a única variável não determinada que corresponde ao nível de expectativa do preço de D no instante $t=T$.

Uma forma de fixar o valor da variável aleatória $D_{T}$ é estabelecendo uma pior situação dentro de um intervalo de confiança para a sua variação. Logo, considerando que a taxa de variação 
de $D_{T}$ seja uma normal de média $\mu_{D}$ e de desvio-padrão $\sigma_{D}$, pode-se, então, a partir disso, fixar $D_{T}$ dentro de uma estimativa máxima de perda, como segue:

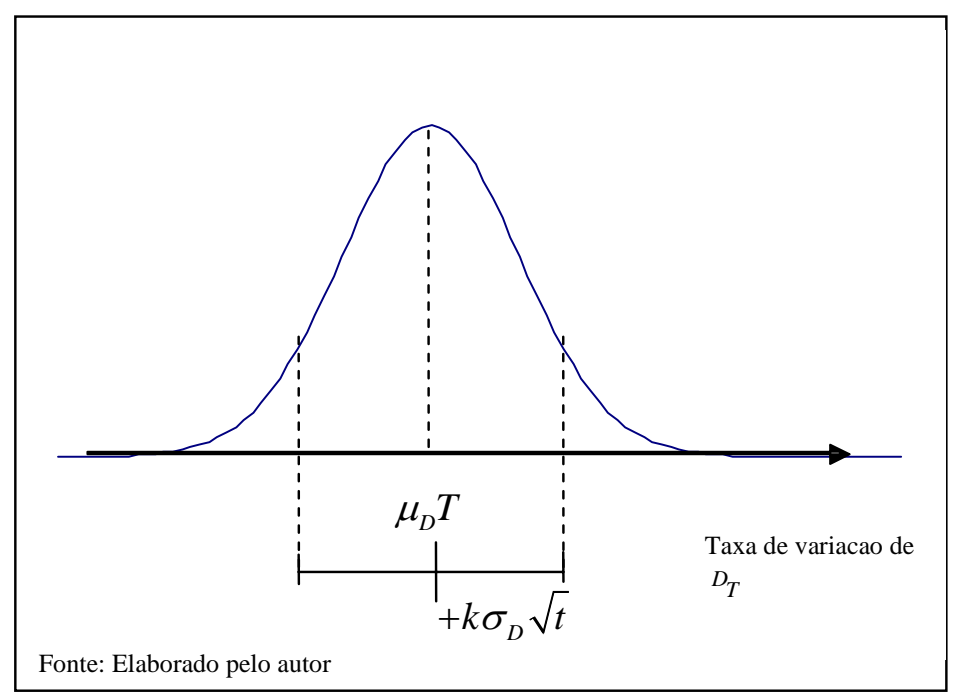

Figura 13 - Fixando $D_{T}$ a partir da sua distribuição de probabilidade

Para tanto $D_{T}$, será tomado como:

$D_{T}=D_{0}\left(1+\left(\mu_{D} t+k \sigma_{D} \sqrt{t}\right)\right)$

Sendo $k$ fixa o nível de confiança escolhido. 


\section{CAPÍTULO 6 - APLICANDO O MODELO PARA O HEDGE PARCIAL ADEQUADO À POLITICA DE HEDGE}

Considere uma empresa que, no inicio de junho/2002, contraia uma dívida de US\$ 10.000.000 ao custo de captação de $10 \%$ a.a. com um prazo de vencimento igual a 1 mês e, como ela tem as suas operações no Brasil, precisará converter o empréstimo em dólar para reais. O hedge será realizado no dia 03/06/2002, data da operação, cujo valor do dólar ptax do dia anterior foi de R\$2,522/US\$1 e admite-se que o custo médio de oportunidade da empresa em relação aos seus investimentos seja igual $I_{a}=30 \%$ a.a. A respeito da escolha da taxa livre de risco, escolheu aquela que vigorava em 03/06/2002, assim, após consultar o site do Banco Central do Brasil (www.bc.gov.br), constatou-se que a taxa livre de risco foi de $r=18,5 \%$ a.a e a taxa livre de risco americana, tomado como referência o T-Bills de três meses, foi de $r_{f}=1,75 \%$ a.a . No anexo, encontra-se a evolução da taxa Selic no período de 15/12/1999 a 14/09/2005.

No ato da operação, a empresa decide fazer o hedge comprando calls na BM\&F - Bolsa de Mercadorias e Futuros. As opções de compra de dólar sobre disponível são através de contratos envolvendo US\$ 50.000 e as cotações são dadas por R\$/US\$ 1.000. Essas opções têm vencimento todos os meses, sempre no primeiro dia útil do mês de vencimento do contrato.

Assim, para que a empresa faça um hedge total da sua posição em risco utilizando os contratos de opção de compra, será necessário que ela adquira um total de:

$$
\frac{10.000 .000 *\left(1+0,1 * \frac{1}{12}\right)}{50.000} \cong 201,67 \text { contratos }
$$


Em 03/06/2002, as opções de compra sobre o disponível na BM\&F estão apresentadas na tabela a seguir:

ATUALIZADO EM: 03/06/2002

\begin{tabular}{|c|c|c|c|c|c|c|c|c|c|}
\hline \multirow{2}{*}{$\begin{array}{c}\text { Dados } \\
\text { SÉRIE/CódIGos }\end{array}$} & \multicolumn{9}{|c|}{ Dados } \\
\hline & $\begin{array}{l}\text { PREÇO } \\
\text { ABERT. }\end{array}$ & $\begin{array}{l}\text { PREÇO } \\
\text { MÍN. }\end{array}$ & $\begin{array}{l}\text { PREÇO } \\
\text { MÁX. }\end{array}$ & $\begin{array}{l}\text { PREÇO } \\
\text { MÉD. }\end{array}$ & $\begin{array}{c}\text { ÚLT. } \\
\text { PREÇO }\end{array}$ & $\begin{array}{l}\text { VAR. } \\
\text { PTOS. }\end{array}$ & $\begin{array}{c}\text { BASE } \\
\text { MARGEM }\end{array}$ & $\begin{array}{c}\text { ÚLT. } \\
\text { OF. } \\
\text { COMPRA }\end{array}$ & $\begin{array}{l}\text { ÚLT. } \\
\text { OF. } \\
\text { VENDA }\end{array}$ \\
\hline JN01 M2C001900 & 0,000 & 0,000 & 0,000 & 0,000 & 0,000 & 0,000 & $1.126,399$ & 0,000 & 0,000 \\
\hline JN03 M2C002000 & 0,000 & 0,000 & 0,000 & 0,000 & 0,000 & 0,000 & $1.026,399$ & 0,000 & 0,000 \\
\hline JN09 M2C002300 & 0,000 & 0,000 & 0,000 & 0,000 & 0,000 & 0,000 & 726,399 & 0,000 & 0,000 \\
\hline JN10 M2C002350 & 0,000 & 0,000 & 0,000 & 0,000 & 0,000 & 0,000 & 676,399 & 0,000 & 0,000 \\
\hline JN11 M2C002400 & 0,000 & 0,000 & 0,000 & 0,000 & 0,000 & 0,000 & 626,399 & 0,000 & 0,000 \\
\hline JN12 M2C002450 & 0,000 & 0,000 & 0,000 & 0,000 & 0,000 & 0,000 & 576,399 & 0,000 & 0,000 \\
\hline JN13 M2C002500 & 0,000 & 0,000 & 0,000 & 0,000 & 0,000 & 0,000 & 526,399 & 0,000 & 0,000 \\
\hline JN14 M2C002550 & 0,000 & 0,000 & 0,000 & 0,000 & 0,000 & 0,000 & 504,400 & 0,000 & 0,000 \\
\hline JN16 M2C002650 & 0,000 & 0,000 & 0,000 & 0,000 & 0,000 & 0,000 & 504,399 & 0,000 & 0,000 \\
\hline JN18 M2C002750 & 0,000 & 0,000 & 0,000 & 0,000 & 0,000 & 0,000 & 504,398 & 0,000 & 0,000 \\
\hline JL01 N2C001900 & 650,900 & 650,900 & 650,900 & 650,900 & 650,900 & $20,900+$ & $1.169,121$ & 0,000 & 0,000 \\
\hline JL03 N2C002000 & 555,100 & 555,100 & 555,100 & 555,100 & 555,100 & 0,000 & $1.069,121$ & 0,000 & 0,000 \\
\hline JL09 N2C002300 & 0,000 & 0,000 & 0,000 & 0,000 & 0,000 & 0,000 & 769,121 & 0,000 & 0,000 \\
\hline JL10 N2C002350 & 0,000 & 0,000 & 0,000 & 0,000 & 0,000 & 0,000 & 719,121 & 0,000 & 0,000 \\
\hline JL11 N2C002400 & 0,000 & 0,000 & 0,000 & 0,000 & 0,000 & 0,000 & 669,121 & 0,000 & 0,000 \\
\hline JL12 N2C002450 & 0,000 & 0,000 & 0,000 & 0,000 & 0,000 & 0,000 & 619,121 & 0,000 & 0,000 \\
\hline JL13 N2C002500 & 0,000 & 0,000 & 0,000 & 0,000 & 0,000 & 0,000 & 569,121 & 0,000 & 0,000 \\
\hline JL14 N2C002550 & 49,900 & 47,400 & 54,300 & 49,629 & 54,000 & $4,900+$ & 519,121 & 0,000 & 0,000 \\
\hline JL15 N2C002600 & 40,000 & 30,700 & 40,000 & 33,574 & 30,700 & $3,700+$ & 504,400 & 0,000 & 0,000 \\
\hline JL16 N2C002650 & 18,400 & 18,400 & 21,200 & 19,705 & 21,200 & $2,200+$ & 504,399 & 0,000 & 0,000 \\
\hline JL17 N2C002700 & 15,000 & 15,000 & 15,000 & 15,000 & 15,000 & $2,000+$ & 504,398 & 0,000 & 0,000 \\
\hline JL19 N2C002800 & 0,000 & 0,000 & 0,000 & 0,000 & 0,000 & 0,000 & 504,397 & 0,000 & 0,000 \\
\hline
\end{tabular}

Tabela 5 - Relação de opções de compra de dólar disponíveis na BM\&F em 03/06/2002

A identificação de cada opção se faz através de uma série e um código. A série é composta por duas letras que indicam o mês de vencimento e os últimos dois algarismos o tipo da opção, ou seja, se ela é uma call ou uma put. Ela será uma call se o final for um número compreendido entre 01 e 25 e uma put, caso contrário.

O código é formado por nove caracteres sendo os cinco primeiros usados como controle da própria BM\&F e os quatro últimos dígitos, o prêmio da opção expresso em R \$/ 1.000 US\$. Assim, tomando, por exemplo, a opção de série JL14 e o código N2C002550, sabe-se que ela 
é uma call e tem vencimento em Julho com o preço de exercício igual a R\$ 2.550 por 1.000 dólares americanos.

Ainda da tabela 5, as cotações apresentadas nas colunas relativas ao preço correspondem ao valor do prêmio de um montante de US\$ 1.000. Assim, a para a liquidação de um contrato de US\$ 50.000, o prêmio médio a ser pago, por exemplo, na opção de série JL14 e o código N2C002550 será igual a R\$2.481,45 que é 50 x R\$49,629. Mais detalhes podem ser obtidos pelas especificações desse contrato que se encontram no anexo deste trabalho.

Admita-se que a empresa tenha uma limitação orçamentária para o hegde de R\$100.000. A volatilidade que será empregada, no nosso caso, será a volatilidade implícita da opção que estiver mais at the money. Da tabela 5, a opção escolhida para a determinação da volatilidade implícita será a JL14N2C002550. Realizando o calculo interativo, com $t=1 / 12, D_{K}=2550$, $r=18,5 \%$ a.a $, r_{f}=1,75 \% a . a, D_{0}=2522$ e $c_{0}=49,629$; obtém-se, pela fórmula de Black \& Scholes modificada para opções de moeda que o valor da volatilidade implícita é igual a $15,84 \%$ a.a.

Para estabelecer o valor de $D_{T}$, ou seja, o valor do dólar após um mês, a empresa estabelece uma pior situação dentro de um intervalo de confiança para a sua variação. Logo, considerando que a taxa de variação de $D_{T}$ seja uma normal de média $\mu_{D}$ e de desvio-padrão $\sigma_{D}$ pode-se, então, a partir disso, fixar $D_{T}$ dentro de uma estimativa máxima de perda. Com base na distribuição de probabilidade dos retornos do dólar ptax no período de jan/2001 a dez/2004, tem-se para um nível de 95\% de confiança que o valor de $D_{T}$ será: 


$$
\begin{aligned}
D_{T} & =D_{0}\left(1+\left(\mu_{D} t+k \sigma_{D} \sqrt{t}\right)\right)=2.522 *(1+(0,08 \% * 21+1,645 * 0,9 \% \cdot \sqrt{21})) \\
& =R \$ 2.740 / U S \$ 1.000
\end{aligned}
$$

Com base nos dados apresentados, o resultado da empresa, após realizar a operação de hedge, será dado por:

$$
R=D_{0} S_{0}^{*}\left(1+I_{a}\right)^{T}-L O\left(1+I_{a}\right)^{T}-h S_{0}^{*}\left(1+I_{c}\right)^{T} \min \left(D_{T}, D_{K}\right)-(1-h) S_{0}^{*}\left(1+I_{c}\right)^{T} D_{T}
$$

Reescrevendo a fórmula acima com a substituição das variáveis literais por suas correspondentes numéricas, tem-se:

$$
\begin{aligned}
R= & 2,522 * 10.000 .000 *(1+30 \%)^{\frac{1}{12}}-100.000 *(1+30 \%)^{\frac{1}{12}}+ \\
& -h * 10.000 .000 *(1+10 \%)^{\frac{1}{12}} * \min \left(2,74 ; D_{K}\right)-(1-h) * 10.000 .000 *(1+10 \%)^{\frac{1}{12}} * 2,74
\end{aligned}
$$

Analisando o resultado final $R$ para uma unidade da dívida que equivale a $S_{0}{ }^{*}=1$ e, conseqüentemente, $\mathrm{m}=1$, tem-se então:

$$
R_{u}=2,522(1+30 \%)^{\frac{1}{12}}-0,010(1+30 \%)^{\frac{1}{12}}-h(1+10 \%)^{\frac{1}{12}} \min \left(2,74 ; D_{K}\right)-2,74(1-h)(1+10 \%)^{\frac{1}{12}}
$$

Deseja-se determinar o valor de $D_{K}{ }^{*}$ que maximiza o resultado, sendo a proporção de hedge $h^{*}$ dada através da relação $h^{*}=\frac{L O_{u}}{m \cdot c_{0}\left(D_{K}{ }^{*}\right)}$, com $m=1$ e $c_{0}\left(D_{K}{ }^{*}\right)$ dada pela fórmula de B\&S para o valor ótimo de $D_{K}{ }^{*}$.

Utilizando os parâmetros fornecidos e a relação de otimalidade já apresentada, obtém-se que a opção escolhida deverá ser com exercício ótimo de R\$ 2.658/U\$ 1000. O valor do prêmio pago por essa opção é dado por: 


$$
\begin{aligned}
d_{1} & =\frac{\ln \left(\frac{D_{0}}{D_{K}^{*}}\right)+\left(r-r_{f}+\frac{\sigma_{D}^{2}}{2}\right) t}{\sigma_{D} \sqrt{t}}=\frac{\ln \left(\frac{2,522}{2,658}\right)+\left(0,185-0,0175+\frac{0,1584^{2}}{2}\right) * \frac{1}{12}}{0,1584 * \sqrt{\frac{1}{12}}} \cong-0,82049 \\
d_{2} & =d_{1}-\sigma \sqrt{t}=-0,82049-0,1584 * \sqrt{\frac{1}{12}} \cong-0,86622 \\
c_{0}^{*} & =D_{0} e^{-r_{f} T} N\left(d_{1}\right)-D_{K}^{*} e^{-r T} N\left(d_{2}\right) \\
& =2,522 * e^{-0,0175^{*} \frac{1}{12} *} N(-0,82049)-2,658 * e^{-0,185^{*} \frac{1}{12}} * N(-0,86622) \\
& \cong 0,013
\end{aligned}
$$

A proporção de hedge $h^{*}$ será igual a:

$$
h^{*}=\frac{L O_{u}}{m \cdot c_{0}\left(D_{K}^{*}\right)}=\frac{0,01}{1.0,013} \cong 77 \%
$$

Portanto, a política de hedge dessa empresa pode ser enunciada da seguinte forma:

Adquirir o contrato com o preço de exercício do contrato mais próximo de R\$2,659 por unidade de US\$ ou de R\$ 2.659 por US\$ 1.000. Dentre os contratos apresentados na tabela 5, aquele que tem essa característica é o de código JL16N2C002650, que tem o preço de exercício de R\$ 2.650 por US\$ 1.000 e prêmio médio por US\$ 1.000 de R\$19,705. Logo, a proporção real de hedge será igual a:

$$
h^{*}=\frac{L O}{m \cdot c_{0}\left(D_{K}^{*}\right)}=\frac{0,01}{1.0,019705} \cong 50,75 \%
$$

Assim o resultado a um nível de confiança de 95\% será de: 


$$
\begin{aligned}
R= & 2,522 * 10.000 .000 *(1+30 \%)^{\frac{1}{12}}-100.000 *(1+30 \%)^{\frac{1}{12}}+ \\
& -0,5075 * 10.000 .000 *(1+10 \%)^{\frac{1}{12}} * \min (2,74 ; 2,65)+ \\
& -(1-0,5075) * 10.000 .000 *(1+10 \%)^{\frac{1}{12}} * 2,74 \cong-1.482 .849
\end{aligned}
$$

Ou seja, o pior resultado a um nível de confiança de 95\% será de R\$ -1.482.849. Com o intuito de entender melhor o pior resultado encontrado, plotou-se o resultado em função do preço do dólar no exercício. Para isso, foram utilizados os mesmos dados anteriormente fornecidos, apenas variando-se preço do dólar no exercício. Observando o gráfico seguinte, tem-se que o seu comportamento é de uma reta decrescente, isso significa que, quanto menor for o preço do dólar no exercício, maior o resultado da operação com o hedge parcial.

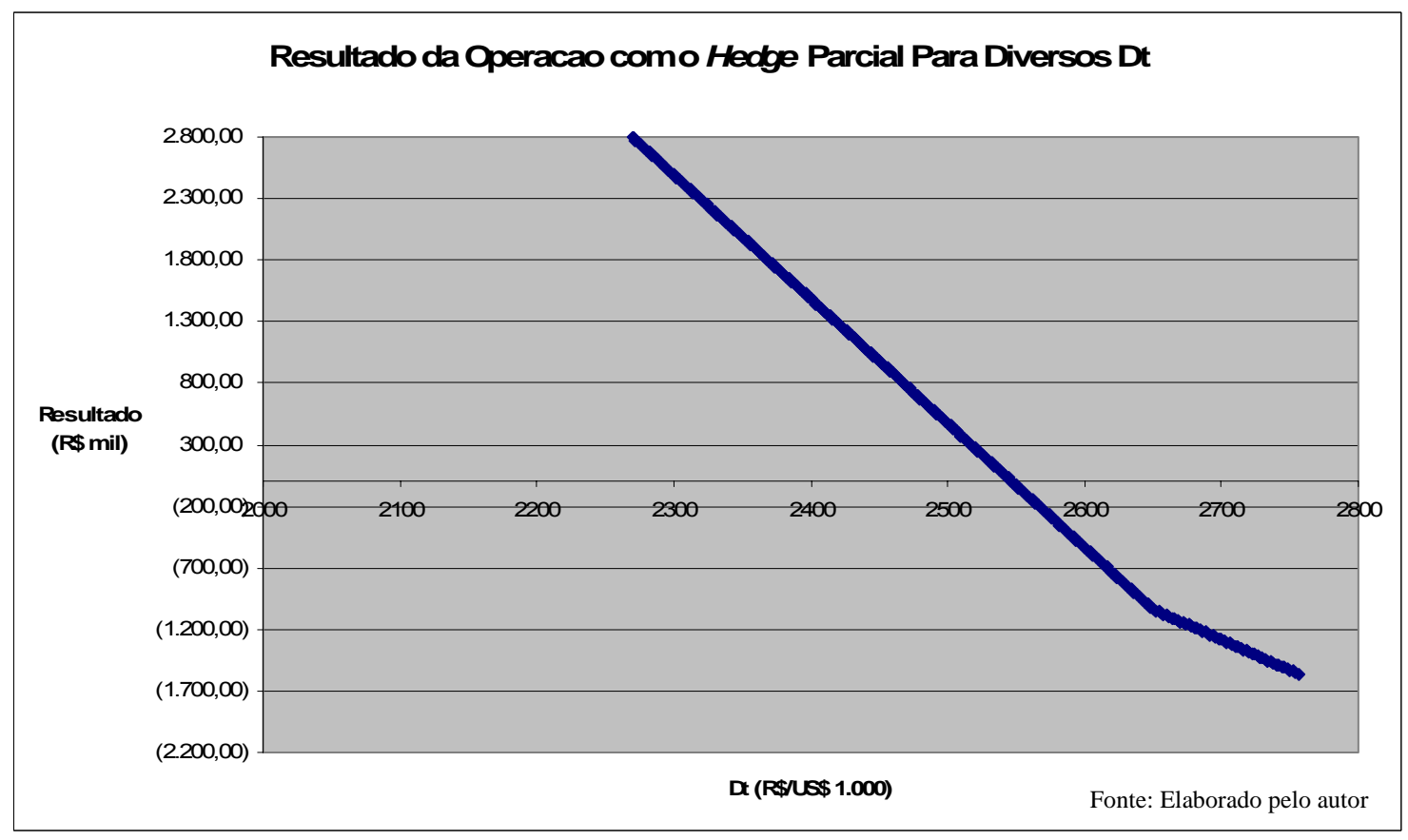

Gráfico 1 - Resultado da operação com o hedge parcial em função de diversos $D_{T}$

Logo, ao afirmar que o pior resultado a um nível de confiança de 95\% será de R\$ -1.482.849, isso significa que, baseando-se na distribuição dos retornos do dólar, tem-se que em apenas 5\% das vezes o dólar fechará acima de $\mathrm{R}$ \$ 2,74/R \$ 1, incorrendo, assim, em perdas maiores do que $\mathrm{R} \$-1.482 .849$. 
Caso fosse escolhida uma outra opção daquela selecionada pelo modelo, os resultados seriam de:

\begin{tabular}{|c|c|c|c|}
\hline Opção & Preço de Exercício & Prêmio Médio & Resultado \\
\hline JL01N2C001900 & $\mathrm{R} \$ 1.900 / \mathrm{US} \$ 1.000$ & $\mathrm{R} \$ 650,9 / \mathrm{R} \$ 1.000$ & $\mathrm{R}$ - 1.811 .410 \\
\hline JL03N2C002000 & $\mathrm{R} \$ 2.000 / \mathrm{US} \$ 1.000$ & $\mathrm{R} \$ 555,1 / \mathrm{R} \$ 1.000$ & $\mathrm{R} \$-1.807 .123$ \\
\hline JL16N2C002650 & $\mathrm{R} \$ 2.650 / \mathrm{US} \$ 1.000$ & $\mathrm{R} \$ 19,705 / \mathrm{R} \$ 1.000$ & $\mathrm{R} \$-1.482 .849$ \\
\hline JL14N2C002550 & $\mathrm{R} \$ 2.550 / \mathrm{US} \$ 1.000$ & $\mathrm{R} \$ 49,629 / \mathrm{R} \$ 1.000$ & $\mathrm{R} \$-1.555 .925$ \\
\hline JL17N2C002700 & $\mathrm{R} \$ 2.700 / \mathrm{US} \$ 1.000$ & $\mathrm{R} \$ 15 / \mathrm{R} \$ 1.000$ & $\mathrm{R} \$-1.673 .847$ \\
\hline
\end{tabular}

Tabela 6 - Resultado do hedge parcial em função dos contratos de dólar disponível

Observando a tabela anterior, verifica-se que mediante as condições de contorno iniciais, dentre elas: a taxa de aplicação, a taxa de captação, a taxa livre de risco doméstica e estrangeira, o nível de confiança. O maior resultado da operação com o hedge parcial obtémse com a opção JL16N2C002650, ou seja, aquela já fornecida pelo modelo. Observa-se um comportamento crescente dos resultados do hedge parcial da opção quando se parte da opção de menor strike até a que fornece o maior resultado, a partir deste momento, ao aumentar o valor do strike há a diminuição do resultado. Esse comportamento do resultado em função do preço do strike, indica a existência de um ponto de máximo. É importante salientar que essas conclusões só valem para o dólar de R\$ 2,74/R \$, previamente fixado por nós.

Com o objetivo de entender melhor o ponto de exercício ótimo encontrado, plotou-se o resultado para cada US\$ 1.000 em função do preço de strike para um limite orçamentário de R\$ 10/1.000US\$. Foram utilizados os mesmos dados anteriormente fornecidos. O gráfico de 
R, em função do preço de strike para o valor de LO = R\$ 10/1.000US\$, pode ser visto a seguir:

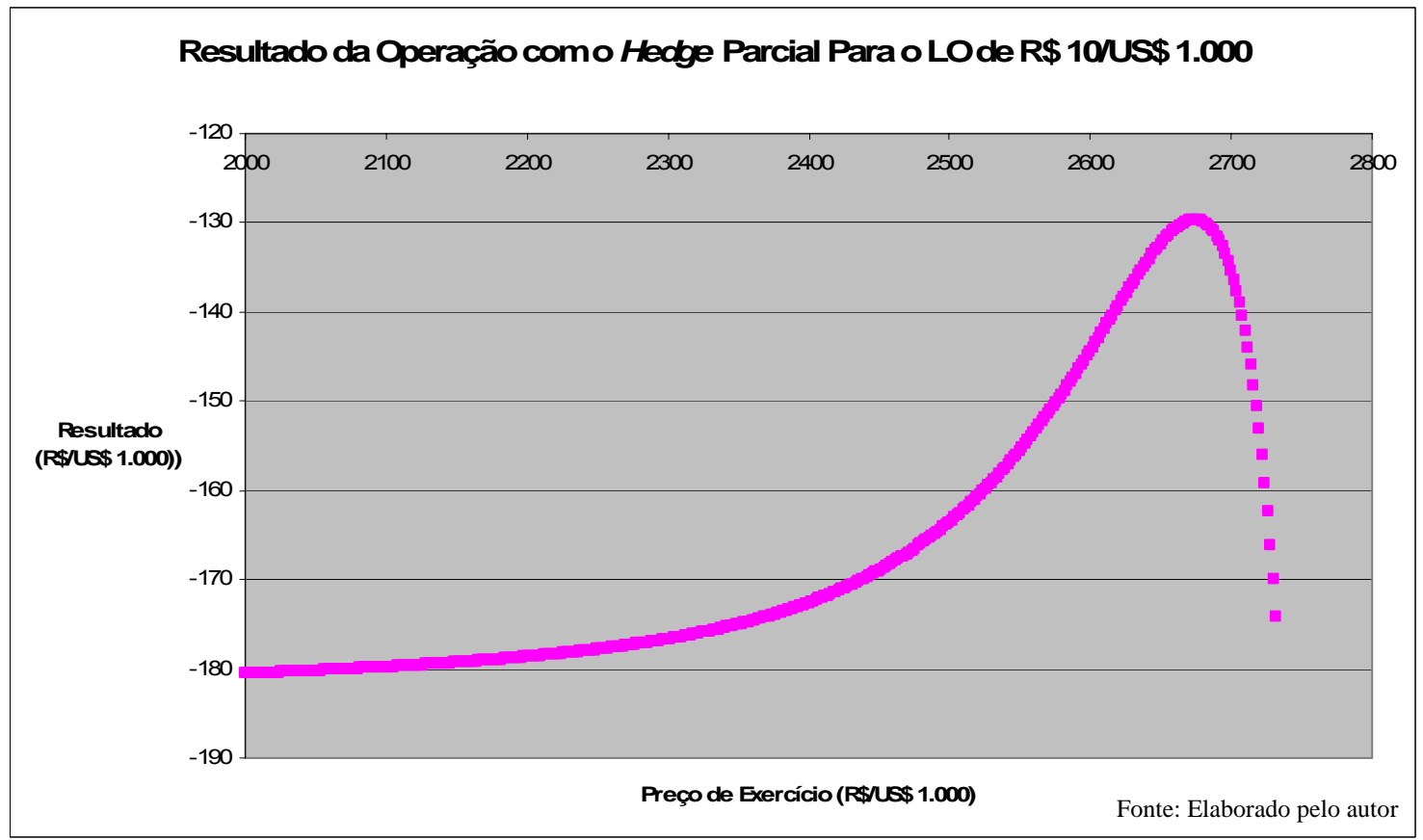

Gráfico 2 - Resultado do hedge parcial em função do preço de strike para um LO de R\$ 10/1.000US\$

Observando o gráfico anterior, percebe-se que o gráfico de $R$ em função do preço de strike possui um valor máximo aproximadamente no preço de strike igual a R\$ 2,65/US\$, ou seja, existe um preço de strike que maximiza $R$.

Visando entender melhor o ponto de exercício ótimo em função de diferentes limites orçamentários, plotou-se o resultado em R\$ por U\$ 1000 em função do preço de strike para três valores fixados de limite orçamentário R\$ 10/1.000US\$, R\$ 15/US\$ 1.000 e R\$ 7/US\$ 1.000. Foram utilizados os mesmos dados anteriormente fornecidos, variando-se apenas o LO. Os gráficos de resultado em função do preço de strike para cada valor de LO, podem ser vistos a seguir: 


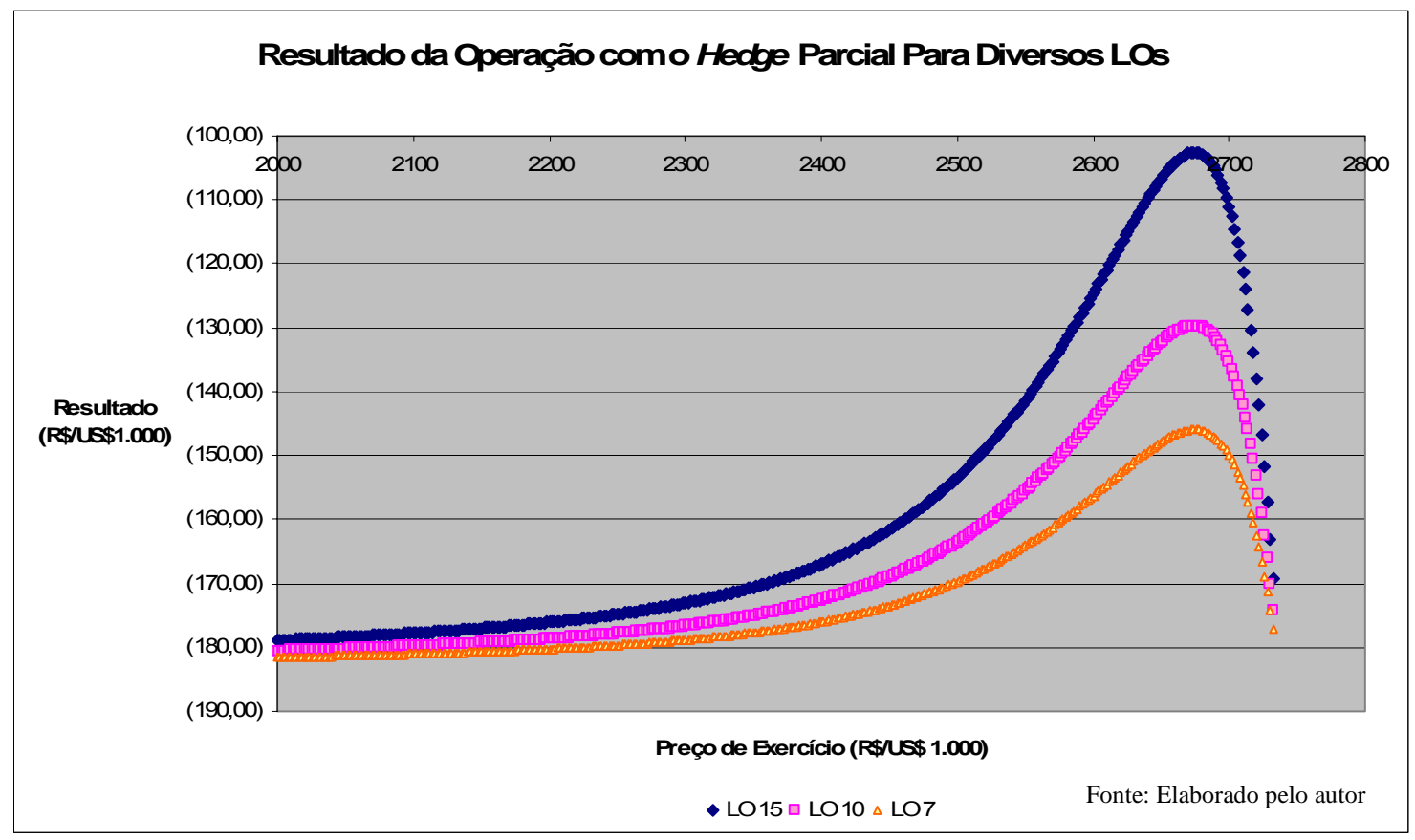

Gráfico 3 - Resultado da operação com o hedge parcial para diversos LOs

É importante notar que, independentemente do LO fixado, o valor de exercício ótimo continuará sendo o mesmo.

Por outro lado, ao fixar não mais o limite orçamentário, mas sim, o resultado que a instituição estaria disposta a incorrer a um dado nível de confiança, verifica-se, nos gráficos seguintes, um ponto de mínimo para o valor do exercício que minimiza o custo do hedge (LO). Esse ponto continua sendo aproximadamente R\$2,65/US\$ independentemente do valor de $R$ ou da perda fixada. 


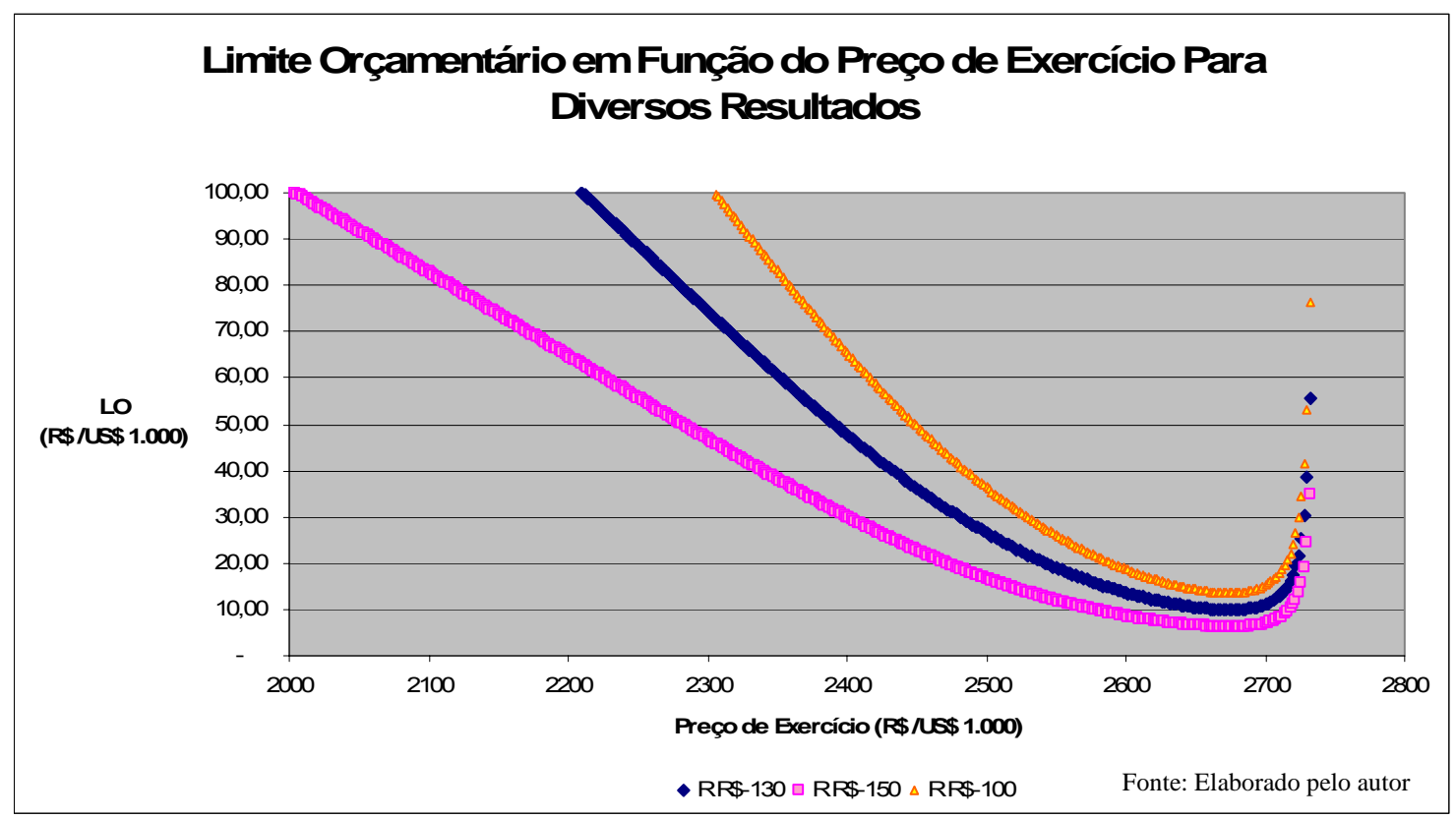

Gráfico 4 - Resultado da operação com o hedge parcial em função do preço de strike para diversos resultados fixados por $R \$$ / US\$ 1.000 


\section{CAPÍTULO 7 - CONSIDERAÇÕES FINAIS}

A política de hedge torna-se uma preocupação crescente para as instituições financeiras.Têmse visto empresas quebrarem pela negligência desse aspecto tão importante na gestão dos riscos corporativos. Assim, este trabalho se propõe a fornecer diretrizes claras e objetivas na formulação dos principais aspectos ligados a uma política de hedge para instituições nãofinanceiras, já que talvez essas sejam as menos dotadas em relação às instituições financeiras, quando o assunto é hedge.

Para caracterizar a política de hedge, balizou-se, basicamente, em três pilares: qual o objeto de hedge, quando fazê-lo e quanto fazer de hedge.

Para responder à primeira questão, procurou-se mostrar ao longo do trabalho que o risco é fundamental para qualquer empresa, corrê-lo é fundamental na obtenção de taxas de retorno acima da taxa livre de risco, é claro, desde que esses riscos sejam intrínsecos ao negócio. Logo, deve-se realizar o hedge de tudo aquilo que não for da competência do negócio e que possa acarretar possíveis perdas nos fluxos futuros para a empresa.

O hedge deve ser feito sempre no ato da abertura da posição de risco, essa é a resposta à segunda questão, a mais fácil de responder, mas a mais difícil de se tomar no dia-a-dia.

Por final, desenvolveu-se um modelo quantitativo para a resposta do último questionamento. As suposições utilizadas na construção do modelo são semelhantes ao que ocorre no dia-a-dia de qualquer empresa; a primeira, que é muito natural, é a existência de uma limitação orçamentária para o hedge, seja em termos da limitação dos recursos, seja com o objetivo de 
evitar o encarecimento do produto final pela incorporação desses custos. Uma outra dificuldade é na escolha da opção de compra dentre universos de prêmios.

O cerne do modelo é fixar um nível de confiança para o valor do ativo na data de vencimento da operação. Isso muito se assemelha à metodologia do VAR, já que, da mesma forma que ele, procurou-se fixar o pior valor do ativo, a um nível de confiança ao considerar um período de tempo. O intuito dessa estratégia é procurar eliminar a aleatoriedade do preço do ativo sem perder de vista o pior cenário que pode acometer a empresa em vista das escolhas do modelo.

O modelo, ao determinar o preço ótimo do strike que otimiza o resultado no pior cenário para a empresa, atinge dois objetivos: o primeiro, fornecer a opção que maximiza o resultado para as condições de contornos e suposições preestabelecidas e, ao mesmo tempo, determina o pior resultado ao nível de confiança escolhido que a empresa incorreria na compra da opção ótima. O segundo, é determinar a proporção ótima do hedge feito, que nada mais é que a relação entre a limitação orçamentária e o total incorrido com os prêmios.

A opção escolhida pelo modelo não depende do limite orçamentário ou da proporção realizada do hedge, e nem de outras variáveis que sejam extrínsecas ao modelo de Black \& Scholes. É interessante perceber que a escolha do preço de exercício ótimo é sensível ao nível de confiança desejado.

Assim, o modelo responde de maneira prática e simples às últimas questões relacionadas a uma política de hedge. 
Para futuras pesquisas seria interessante abordar um modelo mais detalhado da empresa que incluísse decisões de financiamento e os efeitos do hedge na estrutura de capital. Seria, também, de grande valia, abordagens de situações em que a distribuição de probabilidades dos retornos do ativo não fosse a de uma normal. Uma abordagem em que fossem considerados outros fatores de risco que não apenas o preço também seria uma extensão muito interessante do trabalho.

De qualquer maneira espera-se que este trabalho possa ser um auxilio para esses estudos e, assim, diminuir a distância que separa o ideal do real. 


\section{REFERÊNCIAS}

ABRAMO, Perseu. Pesquisa em ciências sociais. In: Hirano, Sedi. Pesquisa Social: projeto e planejamento. São Paulo: T. A. Queiroz , p. 21-88, 1979.

ADAMS, Don. Why Corporations Should Hedge. Disponível em $<$ http //www.cmbf.mq.edu.au/ dadms/ CorporateHedging.pdf>, 2000. Acesso em 08/11/2005.

AHN, D. H.; BOUDOUKH, J.; RICHARDSON, M. e WHITELAW, R. F. Optimal Risk Management Using Options. The Journal of Finance, v. 54, 1999.

ALLAYANNIS, George e WESTON, James P. The use of foreign currency derivatives and firm market value. Review of Financial Studies, v. 14, n ${ }^{0}$ 1, p. 243-276, spring .2001.

ALVES, Nadson J. F. Modelo Conceitual de Mensuração de Resultado para Micro e Pequenas Indústrias. Um enfoque em gestão econômica - GECON. 1998. 125 f. Dissertação de Mestrado - Faculdade de Economia, Administração e Contabilidade, Universidade de São Paulo, São Paulo, 1998.

BERNSTEIN, Peter L. Desafio aos Deuses: A Fascinante História do Risco. $2^{a}$ Edição. São Paulo: Editora Campus, 1997.

BESANCO, David; DRANOVE, David; SHARNLEY, Mark. Economics of Strategy. $2^{\text {a }}$ Edição New Jersey: John Wiley \& Sons, 2000.

BETHLEM, Agrícola de S. Política e Estratégia de Empresas. Rio de Janeiro: Editora Guanabara Dois S.A., 1981.

BLACK, Fisher. e SCHOLES, Myron. The Pricing of Options and Corporate Liabilities. The Journal of Political Economy, v. 81, nº 3, p. 637 - 654, 1973.

BLACK, Fisher. How to Use yhe Holes in Black-Scholes. Journal of Applied Corporate Finance, v. 1, n ${ }^{\circ}$ 4, p. 67-73, 1989.

BROWN, Gregory W. e TOFT, Klaus B. How Firms Should Hedge. Review of Financial Studies, v. 15, nº 4, p. 1283-1324, 2002.

BUCKLEY, Adrian. Multinational finance. $3^{\mathrm{a}}$ Edição Great Britain: Prentice Hall Europe, 1996.

BUTLER, Kirt C. Multinational Finance. $2^{\mathrm{a}}$ Edição, Ohio: South-Western College Publishing, 2000.

CARVALHO, Luiz N. G. Uma contribuição à Auditoria do Risco de Derivativos. 1996. 155 f. Tese de Doutorado - Faculdade de Economia, Administração e Contabilidade, Universidade de São Paulo, São Paulo, 1996.

CATELLI, Armando. Controladoria: Uma abordagem da Gestão Econômica GECON, São Paulo: Editora Atlas, 1999. 
CFTC. Glossary of Trading Terms, Washington, 1982.

CHIAVENETO, Idalberto. Administração de recursos humanos: fundamentos básicos, São Paulo: Editora Atlas, 1999.

COMINI, Marcos L. Modelo de apuração de resultado para o segmento metal-mecânico sob a ótica do GECON: Um estudo baseado nas indústrias de Joaçaba - Santa Catarina. 2003. 167 f. Dissertação de Mestrado - Faculdade de Economia, Administração e Contabilidade, Universidade de São Paulo, São Paulo, 2003.

COMMODITY FUTURES TRADING COMISSION. Glossary of Trading Terms. Washington, DC, 1982.

COPELAND, Thomas E. e WESTON, John F. Financial Theory and Corporate Policy. $3^{\text {a }}$ Edição. USA: Addison Wesley Publishing Company, 1988.

COX, John; RUBINSTEIN, Mark; ROSS, Stephen. Option Pricing: A Simplified Approach. Journal of Financial Economics, v.7, nº 3, p. 229-263, Sept. 1979.

CROUHY, Michel; GALAI, Dan; MARK, Robert. Gerenciamento de Risco: Abordagem Conceitual e Prática. São Paulo: Editora Qualitymark, 2004.

DAMODARAN, Aswath. Avaliação de Investimentos: Ferramentas e Técnicas para a determinação do valor de qualquer ativo. São Paulo: Editora Qualitymark., 2003.

DEMARZO, Peter M. e DUFFIE, Darrell. Corporate incentives for hedging and hedge accounting. The Review of Financial Studies, v. 8, nº 3, p. 743-771, Autumn 1995.

DEMARZO, Peter M. e DUFFIE, Darrell. Corporate financial hedging with proprietary information. Journal of Economic Theory, v. 53, p. 261-286, 1991.

DUARTE JÚNIOR, Antonio M. Risco: Definições, Tipos, Medição e Recomendações para o seu gerenciamento. In: LEMGRUGER, Eduardo F; CARVALHAL DA SILVA, André L; LEAL, Ricardo P. C; COSTA JR., Newton C. A. Gestão de risco e derivativos: aplicações no Brasil. São Paulo: Editoda Atlas, p. 103 - 111, 2001.

FABOZZI, Frank J. Financial Management \& Analysis. $2^{\text {a }}$ Edição. New Jersey: John Wiley \& Sons, 2003.

FAMÁ, Rubens e CHAIA, Alexandre J. Teorias da previsão da taxa de câmbio: um teste de eficiência no Brasil, Chile e México na segunda metade dos anos 90. Caderno de pesquisa em Administração, v. 8, $n^{0}$ 2, p. 57-69, 2001.

FLIPPO, Edwin B. Principios de Administração de Pessoal. 2 ${ }^{a}$ Edição. São Paulo: Atlas, 1975.

FORBES, Luis F. Mercados Futuros: Uma introdução. São Paulo: Bolsa de Mercadorias \& Futuros, 1994. 
FRANCIS, Jack C. Management of Investment. 3ª Edição. New York: McGraw-Hill, , 1993.

FROOT, Kenneth A; SCHARFSTEIN, David; STEIN, Jeremy C. Risk management: Coordinating corporate investment and financing policies. The Journal of Finance, v. 48, $\mathrm{n}^{\mathrm{o}}$. 5, p. 1629-1658, 1993.

FUTURES INDUSTRY INSTITUTE. Curso de Futuros e Opções. São Paulo: Bolsa de Mercadorias \& Futuros, 1998.

GECZY, Christopher, MINTON, Bernadette A. e SCHRAND, Catherine. Why Firms Use Currency Derivatives. The Journal of Finance, v. 52, nº 4, p. 1323-1354, 1997.

GIMENES, Cristiano M. e FAMÁ, Rubens. A correlação entre o risco país e índices de bolsa da América Latina: Um estudo exploratório. Caderno de pesquisa em Administração, v. 10, $n^{0}$ 2, p. 39-50, 2003.

GLOBAL DERIVATIVES STUDY GROUP. Derivatives: practices and principles. Disponível em <http // www.group30.org/pubs.php?page=pubs1993.html >, 1993.

GOULART, André M. C. Evidenciação Contábil do Risco de Mercado por Instituições Financeiras no Brasil. 2003. 201 f. Dissertação de Mestrado - Faculdade de Economia, Administração e Contabilidade, Universidade de São Paulo, São Paulo, 2003.

GRAHAM, John R. e ROGERS, Daniel A. Do Firms Hedge in Response to Tax Incentives? The Journal of Finance, vol. 57, n ${ }^{0}$ 2, p.815-838, 2002.

GUAY, Wayne e KOTHARI, S.P. How much do firms hedge with derivatives? Journal of Financial Economics, v. 70, $n^{0}$ 3, p. 423-461, dez. 2003.

HEDGE. In: Cambridge international dictionary of english. Cambridge: Cambridge University Press, 1995. p. 659.

HOBSBAWN, Eric J. Era dos Extremos: O breve século XX: 1914 - 1991. São Paulo: Editora Companhia das Letras, 1995.

HULL, John: Options, Futures, and other Derivatives. $3^{\mathrm{a}}$. Edição. New Jersey: Prentice Hall, 1997.

HULL, John: Options, Futures, and other Derivatives. 5ª Edição. New Jersey: Prentice Hall, 2002.

JORION, Philippe. Value at Risk: A Nova Fonte de Referência para o Controle do Risco de Mercado. São Paulo: Bolsa de Mercadorias \& Futuros, 1998.

JORION, Philippe. Financial Risk Manager Handbook. $2^{\text {a }}$ Edição. New Jersey: John Wiley \& Sons, 2003. 
KNIGHT, Frank H. Risco, Incerteza e Lucro. Rio de Janeiro: Editora Expressão e Cultura,, 1972.

KOLB, R. Understanding Options. New Jersey: John Wiley \& Sons, 1995.

KURTZMAN, Joel. A Morte do Dinheiro: Como a economia eletrônica desestabilizou os mercados mundiais e criou o caos financeiro. São Paulo: Editora Atlas, 1995.

LEWENT, J. C. e KEARNEY, A. J. Identifying, measuring and hedging currency risk at Merck. Journal of Applied Corporate Finance, v. 2, p. 19-28. 1990.

MAYERS, D. e SMITH, Clifford W. On the Corporate Demand for Insurance: Evidence from the Reinsurance Market. The Journal of Business, v. 63, n 1, p. 19-41, 1990.

MIAN, Shehzad L. Evidence on Corporate Hedging Policy. The Journal of Financial and Quantitative Analysis, v. 31, n 3, p. 419-439, 1996.

MILLER, Merton H. Merton Miller on Derivatives. New Jersey: John Wiley \& Sons, 1997.

MORELLEC, Erwan e SMITH, Clifford W Jr. Investment policy, financial policies, and the control of the agency conflicts. Working paper N0. FR 02-16: Simon School of Business, 2002.

NANCE, Deana R. SMITH, Clifford W. e SMITHSON, Charles W. On the Determinants of Corporate Hedging. The Journal of Finance, vol. 48, nº 1, p. 267-284, 1993.

PETERSEN, Mitchell A. e THIAGARAJAN, S. R. Risk Measurement and Hedging: with and without derivatives. Financial Management, v. 29, nº 4, p. 5-30, winter 2000.

PORTER, Michael. A nova era da estratégia. In: JÚLIO, Carlos A e SALIBI NETO, José. Estratégia e Planejamento: autores e conceitos imprescíndiveis. São Paulo: Publifolha, p. 21-38, 2002.

REEKIE, W Duncan e CROOK, Jonathan N. Managerial economics: a european text. $4^{\text {a }}$ Edição. New Jersey: Prentice Hall, 1995.

RUBINSTEIN, Mark. Rubinstein on Derivatives. Great Britain: Risk Books, 1999.

SAITO, Richard e SCHIOZER, Rafael F. Uso de derivativos em empresas brasileiras nãofinanceiras. Resenha BM\&F, São Paulo, nº 163, p. 51 - 58, 2005.

SANTOS, Roberto V. dos. Modelo de decisão para gestão de preço de venda. 1995. $346 \mathrm{f}$. Dissertação de Mestrado - Faculdade de Economia, Administração e Contabilidade, Universidade de São Paulo, São Paulo, 1995.

SECURATO, José R. Um modelo para quantificar o risco de crédito. 2000. 122 f. Tese de Livre Docência - Faculdade de Economia, Administração e Contabilidade, Universidade de São Paulo, São Paulo, 2000. 
SHARPE, William F. Capital Asset Prices: A Theory of Market Equilibrium under Conditions of Risk. The Journal of Finance, v. 19, nº 3, p. 425-442, 1964.

SHARPE, William F.; ALEXANDER, Gordon J.; BAILEY, Jeffery V. Investments. $6^{\text {a }}$ Edição. New Jersey: Prentice Hall, 1998.

SIEGEL, Daniel R. e SIEGEL, Diane F. Future Markets. Orlando: The Dryden Press, 1990.

SLYWOTZKY, Adrian J. e MORRISON, David J. A Estratégia Focada no Lucro. São Paulo: Editora Campus, 1998.

SMITHSON, Charles. Does risk management work? Risk, p. 44-45, Jul. 1999.

SMITHSON, Charles W.; SMITH, Clifford W.; WILFORD, D. S. Managing Financial Risk: A Guide to Derivative Products, Financial Engineering and Value Maximization. Chicago: Irwin, 1995.

SPENCER, Milton H.; SEO, K. K.; SIMKI, Mark G. Managerial economics Text, Problems, and Short Cases. 4 Edição. Illinois: Richard D. Irwin, Inc., 1975.

SMITH, Clifford W. e STULZ, René M. The Determinants of Corporate Hedging. Journal of Financial and Quantitative Analysis, v. 20, nº.4, p. 391-405, 1985.

WORKING, Holbrook. New concepts concerning futures markets and price. The American Economic Review, v.52, nº 3, p.431-459, June 1962. 


\section{APÊNDICES}

\section{MODELO DE PRECIFICAÇÂO BINOMIAL}

Considere-se que o ativo e a call sigam um processo binomial multiplicativo. Dessa forma, em cada período de tempo, os preços podem subir ou descer com uma dada probabilidade. Logo, se o preço spot do ativo é $S_{0}$, o preço no fim do período poderá ser $S_{0} u$ com probabilidade $p$ ou $S_{0} d$ com probabilidade $(1-p)$. Essa situação está representada abaixo:

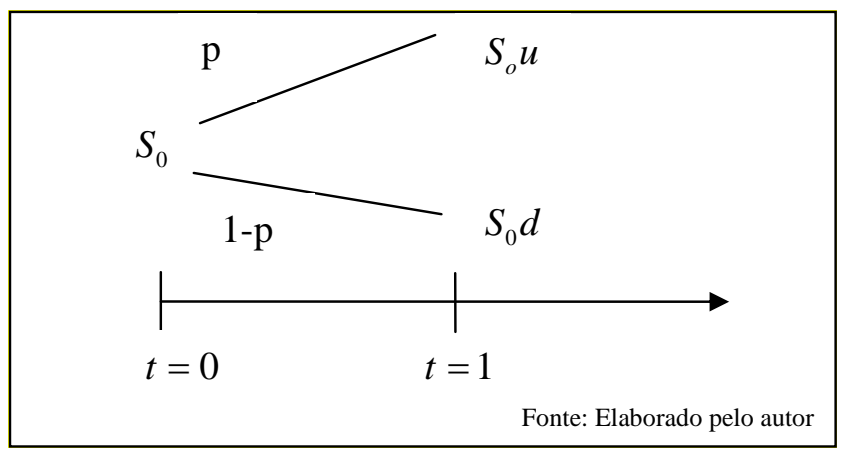

Obtido pela árvore binomial o preço do ativo na data $t=1$, pode-se estabelecer o preço da call nessa data para um valor de exercício $K$, dado por:

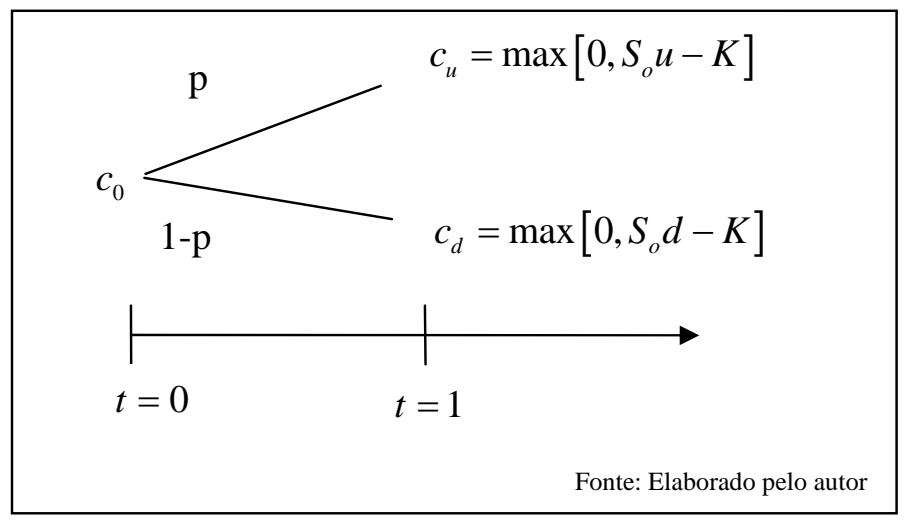

Utilizando a abordagem probabilística neutra ao risco, vale a relação: 


$$
\begin{aligned}
& S_{0}\left(1+i_{f}\right)=p u S_{0}+(1-p) d S_{0} \\
& p=\frac{\left(1+i_{f}\right)-d}{u-d}
\end{aligned}
$$

Que permitirá voltar para a data $t=0$ a uma taxa livre de risco $i_{f}$ e obter o preço $c_{0}$ da call dado por:

$$
c_{0}=\frac{c_{u} p+c_{d}(1-p)}{\left(1+i_{f}\right)}
$$

sendo $p$ a probabilidade neutra ao risco.

A construção da árvore binomial relativa ao preço do ativo pode ser estendida até o período que se desejar $t=n$, e nesse caso os possíveis valores do ativo serão $S_{0} u^{j} d^{n-j}$ com probabilidade $\left(\begin{array}{c}n \\ j\end{array}\right) p^{j}(1-p)^{n-j}$, o que dá a distribuição de probabilidades na data $t=n$.

Estabelecendo o valor da opção na data $t=n$ dada por $\max \left[0 ; S_{0} u^{j} d^{n-j}-K\right]$, pode-se voltar para a data $t=0$ e obter o preço $c_{0}$ da call de exercício $X$ para $t=n$, como segue:

$$
C_{0}=\frac{\sum_{j=0}^{n}\left(\begin{array}{l}
n \\
j
\end{array}\right)(p)^{j}(1-p)^{n-j} \max \left[0, S_{0} \cdot u^{j} \cdot d^{n-j}-K\right]}{\left(1+i_{f}\right)^{n}}
$$

A expressão acima pode ser simplificada, imaginando que ao final de $n$ a opção tenha acabado dentro do dinheiro para $\underline{a}$ subidas. Assim, pode-se indicar que $\frac{p \cdot u}{\left(1+i_{f}\right)}=q$, que substituindo em (2) dará:

$$
c_{0}=S_{0}\left[\sum_{j=a}^{n}\left(\begin{array}{l}
n \\
j
\end{array}\right)(q)^{j}(1-q)^{n-j}\right]-K .\left(1+i_{f}\right)^{-n}\left[\sum_{j=a}^{n}\left(\begin{array}{c}
n \\
j
\end{array}\right)(p)^{j}(1-p)^{n-j}\right]
$$


Indicando por $\sum_{j=a}^{n}\left(\begin{array}{c}n \\ j\end{array}\right)(q)^{j}(1-q)^{n-j} \underline{\underline{n o t}} \Phi[a ; n ; q]$ e $\sum_{j=a}^{n}\left(\begin{array}{c}n \\ j\end{array}\right)(p)^{j}(1-p)^{n-j} \underline{\underline{n o t}} \Phi[a ; n ; p]$, temse:

$c_{0}=S_{0} \Phi[a ; n ; q]-X\left(1+i_{f}\right)^{-n} \Phi[a ; n ; p]$

observando que essa notação corresponde a uma distribuição binomial.

Sendo:

$a=$ o menor inteiro não negativo maior que $\ln \left(\frac{K}{S_{0} d^{n}}\right) / \ln \left(\frac{u}{d}\right) \quad$ e $\quad p=\frac{d-i_{f}}{d-u}$

o que pode ser visto em Cox, Rubinstein e Ross (1979, pg. 229:263).

Uma outra maneira de chegar na fórmula de precificação de uma call é utilizando a abordagem de uma carteira replicada. Ou seja, o retorno da opção pode ser replicado através de uma carteira combinada com o ativo objeto e o ativo livre de risco. Isto é feito observando, que a opção e o ativo objeto são perfeitamente correlacionados, positivamente no caso da call e negativamente no caso da put. Desta maneira, pela teoria do preço único a carteira replicada e a opção geraram os mesmos retornos, caso contrário haverá operações de arbitragem dos participantes do mercado. Considerando a árvore binomial da opção e do ativo objeto apresentado, é correto:

$\left\{\begin{array}{l}B S_{0} u+M\left(1+i_{f}\right)=c_{u} \\ B S_{0} d+M\left(1+i_{f}\right)=c_{d}\end{array}\right.$

Sendo B é a quantidade do ativo objeto na carteira, também conhecido como delta da opção, e M é a quantidade do ativo livre de risco. Resolvendo o sistema acima tem-se que:

$$
B=\frac{c_{u}-c_{d}}{S_{0} u-S_{0} d} \quad e \quad M=\frac{u c_{d}-d c_{u}}{(u-d)\left(1+i_{f}\right)}
$$

Assim, o valor da call será: 


$$
\begin{aligned}
c_{0}= & B S_{0}+M \\
= & \frac{c_{u}-c_{d}}{u-d}+\frac{u c_{d}-d c_{u}}{(u-d)\left(1+i_{f}\right)} \\
& =\frac{c_{u} \frac{\left[\left(1+i_{f}\right)-d\right]}{(u-d)}+c_{d} \frac{\left[u-\left(1+i_{f}\right)\right]}{(u-d)}}{\left(1+i_{f}\right)}
\end{aligned}
$$

Fazendo $\frac{\left[\left(1+i_{f}\right)-d\right]}{(u-d)}=p$ e conseqüentemente, $\frac{\left[u-\left(1+i_{f}\right)\right]}{(u-d)}=1-p$ tem se:

$$
c_{0}=\frac{c_{u} p+c_{d}(1-p)}{\left(1+i_{f}\right)}
$$

sendo $p$ a probabilidade neutra ao risco.

Ou seja, o mesmo resultado obtido anteriormente para um período. Para precificar opções com maturidade com períodos maiores que um, procede-se de forma interativa do último período até o período atual. 


\section{ANEXOS}

Histórico das taxas de juros fixadas pelo Copom e evolução da taxa

\begin{tabular}{|c|c|c|c|c|c|c|c|}
\hline & & & Período de vigência & $\begin{array}{c}\text { Meta SELI C } \\
\% \text { a.a. }\end{array}$ & $\begin{array}{l}\text { TBAN } \\
\% \text { a.m. }\end{array}$ & & ra SELI C \\
\hline no & data & viés & & $(1)(6)$ & & $\underline{-3 \%}$ & \% a.a. (4) \\
\hline $112^{\mathrm{a}}$ & $14 / 9 / 2005$ & & 15/09/2005 - & 19,5 & & & \\
\hline $111^{\mathrm{a}}$ & $17 / 8 / 2005$ & & $18 / 08 / 2005-14 / 09 / 2005$ & 19,75 & & 1,4 & 19,74 \\
\hline $110^{\mathrm{a}}$ & $20 / 7 / 2005$ & & $21 / 07 / 2005-17 / 08 / 2005$ & 19,75 & & 1,4 & 19,75 \\
\hline $109^{a}$ & $15 / 6 / 2005$ & & $16 / 06 / 2005-20 / 07 / 2005$ & 19,75 & & 1,8 & 19,73 \\
\hline $108^{\mathrm{a}}$ & $18 / 5 / 2005$ & & $19 / 05 / 2005-15 / 06 / 2005$ & 19,75 & & 1,4 & 19,75 \\
\hline $107^{\mathrm{a}}$ & $20 / 4 / 2005$ & & $22 / 04 / 2005-18 / 05 / 2005$ & 19,5 & & 1,4 & 19,51 \\
\hline $106^{\mathrm{a}}$ & $16 / 3 / 2005$ & & $17 / 03 / 2005-21 / 04 / 2005$ & 19,25 & & 1,7 & 19,24 \\
\hline $105^{\mathrm{a}}$ & $16 / 2 / 2005$ & & $17 / 02 / 2005-16 / 03 / 2005$ & 18,75 & & 1,4 & 18,75 \\
\hline $104^{\mathrm{a}}$ & $19 / 1 / 2005$ & & $20 / 01 / 2005-16 / 02 / 2005$ & 18,25 & & 1,2 & 18,25 \\
\hline $103^{\mathrm{a}}$ & $15 / 12 / 2004$ & & $16 / 12 / 2004-19 / 01 / 2005$ & 17,75 & & 1,6 & 17,74 \\
\hline $102^{\mathrm{a}}$ & $17 / 11 / 2004$ & & $18 / 11 / 2004-15 / 12 / 2004$ & 17,25 & & 1,3 & 17,23 \\
\hline $101^{\mathrm{a}}$ & $20 / 10 / 2004$ & & $21 / 10 / 2004-17 / 11 / 2004$ & 16,75 & & 1,1 & 16,71 \\
\hline $100^{\mathrm{a}}$ & $15 / 9 / 2004$ & & $16 / 09 / 2004-20 / 10 / 2004$ & 16,25 & & 1,4 & 16,23 \\
\hline $99^{\mathrm{a}}$ & $18 / 8 / 2004$ & & $19 / 08 / 2004-15 / 09 / 2004$ & 16 & & 1,1 & 15,9 \\
\hline $98^{\mathrm{a}}$ & $21 / 7 / 2004$ & & $22 / 07 / 2004-18 / 08 / 2004$ & 16 & & 1,2 & 15,83 \\
\hline $97^{\mathrm{a}}$ & $16 / 6 / 2004$ & & $17 / 06 / 2004-21 / 07 / 2004$ & 16 & & 1,5 & 15,79 \\
\hline $96^{\mathrm{a}}$ & $19 / 5 / 2004$ & & $20 / 05 / 2004-16 / 06 / 2004$ & 16 & & 1,1 & 15,79 \\
\hline $95^{\mathrm{a}}$ & $14 / 4 / 2004$ & & $15 / 04 / 2004-19 / 05 / 2004$ & 16 & & 1,4 & 15,8 \\
\hline $94^{\mathrm{a}}$ & $17 / 3 / 2004$ & & $18 / 03 / 2004-14 / 04 / 2004$ & 16,25 & & 1,1 & 16,09 \\
\hline $93^{\mathrm{a}}$ & $18 / 2 / 2004$ & & $19 / 02 / 2004-17 / 03 / 2004$ & 16,5 & & 1,1 & 16,28 \\
\hline $92^{\mathrm{a}}$ & $21 / 1 / 2004$ & & $22 / 01 / 2004-18 / 02 / 2004$ & 16,5 & & 1,2 & 16,3 \\
\hline $91^{\mathrm{a}}$ & $17 / 12 / 2003$ & & $18 / 12 / 2003-21 / 01 / 2004$ & 16,5 & & 1,4 & 16,32 \\
\hline $90^{\mathrm{a}}$ & $19 / 11 / 2003$ & & $20 / 11 / 2003-17 / 12 / 2003$ & 17,5 & & 1,3 & 17,32 \\
\hline $89^{a}$ & $22 / 10 / 2003$ & & $23 / 10 / 2003-19 / 11 / 2003$ & 19 & & 1,4 & 18,84 \\
\hline $88^{\mathrm{a}}$ & $17 / 9 / 2003$ & & $18 / 09 / 2003-22 / 10 / 2003$ & 20 & & 1,8 & 19,84 \\
\hline $87^{\mathrm{a}}$ & $20 / 8 / 2003$ & & $21 / 08 / 2003-17 / 09 / 2003$ & 22 & & 1,6 & 21,84 \\
\hline $86^{a}$ & $23 / 7 / 2003$ & & $24 / 07 / 2003-20 / 08 / 2003$ & 24,5 & & 1,7 & 24,32 \\
\hline $85^{\mathrm{a}}$ & $18 / 6 / 2003$ & & $19 / 06 / 2003-23 / 07 / 2003$ & 26 & & 2,2 & 25,74 \\
\hline $84^{\mathrm{a}}$ & $21 / 5 / 2003$ & & $22 / 05 / 2003-18 / 06 / 2003$ & 26,5 & & 1,9 & 26,27 \\
\hline $83^{\mathrm{a}}$ & $23 / 4 / 2003$ & & $24 / 04 / 2003-21 / 05 / 2003$ & 26,5 & & 1,8 & 26,32 \\
\hline $82^{\mathrm{a}}$ & $19 / 3 / 2003$ & alta & $20 / 03 / 2003-23 / 04 / 2003$ & 26,5 & & 2,2 & 26,32 \\
\hline $81^{\mathrm{a}}$ & $19 / 2 / 2003$ & & $20 / 02 / 2003-19 / 03 / 2003$ & 26,5 & & 1,7 & 26,3 \\
\hline $80^{\mathrm{a}}$ & $22 / 1 / 2003$ & & $23 / 01 / 2003-19 / 02 / 2003$ & 25,5 & & 1,8 & 25,36 \\
\hline $79^{a}$ & $18 / 12 / 2002$ & & $19 / 12 / 2002-22 / 01 / 2003$ & 25 & & 2,1 & 24,9 \\
\hline $78^{\mathrm{a}}$ & $20 / 11 / 2002$ & & $21 / 11 / 2002-18 / 12 / 2002$ & 22 & & 1,6 & 21,9 \\
\hline $77^{\mathrm{a}}$ & $23 / 10 / 2002$ & & $24 / 10 / 2002-20 / 11 / 2002$ & 21 & & 1,4 & 20,9 \\
\hline $76^{\mathrm{a}} \mathrm{ex}$. & $14 / 10 / 2002$ & & $15 / 10 / 2002-23 / 10 / 2002$ & 21 & & 0,5 & 20,9 \\
\hline $75^{\mathrm{a}}$ & 18/9/2002 & & $19 / 09 / 2002-14 / 10 / 2002$ & 18 & & 1,2 & 17,9 \\
\hline $74^{\mathrm{a}}$ & $21 / 8 / 2002$ & baixa & $22 / 08 / 2002-18 / 09 / 2002$ & 18 & & 1,3 & 17,87 \\
\hline $73^{a}$ & $17 / 7 / 2002$ & & $18 / 07 / 2002-21 / 08 / 2002$ & 18 & & 1,6 & 17,86 \\
\hline $72^{\mathrm{a}}$ & $19 / 6 / 2002$ & baixa & $20 / 06 / 2002-17 / 07 / 2002$ & 18,5 & & 1,4 & 18,4 \\
\hline $71^{\mathrm{a}}$ & $22 / 5 / 2002$ & & $23 / 05 / 2002-19 / 06 / 2002$ & 18,5 & & 1,3 & 18,07 \\
\hline $70^{\mathrm{a}}$ & $17 / 4 / 2002$ & & $18 / 04 / 2002-22 / 05 / 2002$ & 18,5 & & 1,6 & 18,35 \\
\hline $69^{\mathrm{a}}$ & $20 / 3 / 2002$ & & $21 / 03 / 2002-17 / 04 / 2002$ & 18,5 & & 1,3 & 18,45 \\
\hline $68^{\mathrm{a}}$ & $20 / 2 / 2002$ & & $21 / 02 / 2002-20 / 03 / 2002$ & 18,75 & & 1,4 & 18,8 \\
\hline $67^{\mathrm{a}}$ & $23 / 1 / 2002$ & & $24 / 01 / 2002-20 / 02 / 2002$ & 19 & & 1,3 & 19,05 \\
\hline $66^{a}$ & $19 / 12 / 2001$ & & $20 / 12 / 2001-23 / 01 / 2002$ & 19 & & 1,6 & 19,05 \\
\hline $65^{\mathrm{a}}$ & $21 / 11 / 2001$ & & $22 / 11 / 2001-19 / 12 / 2001$ & 19 & & 1,4 & 19,05 \\
\hline $64^{\mathrm{a}}$ & $17 / 10 / 2001$ & & $18 / 10 / 2001-21 / 11 / 2001$ & 19 & & 1,6 & 19,05 \\
\hline $63^{a}$ & 19/9/2001 & & $20 / 09 / 2001-17 / 10 / 2001$ & 19 & & 1,3 & 19,07 \\
\hline $62^{\mathrm{a}}$ & $22 / 8 / 2001$ & & $23 / 08 / 2001-19 / 09 / 2001$ & 19 & & 1,3 & 19,04 \\
\hline $61^{\mathrm{a}}$ & $18 / 7 / 2001$ & & $19 / 07 / 2001-22 / 08 / 2001$ & 19 & & 1,7 & 18,96 \\
\hline $60^{\mathrm{a}}$ & $20 / 6 / 2001$ & baixa & $21 / 06 / 2001-18 / 07 / 2001$ & 18,25 & & 1,3 & 18,31 \\
\hline $59^{\mathrm{a}}$ & $23 / 5 / 2001$ & & $24 / 05 / 2001-20 / 06 / 2001$ & 16,75 & & 1,2 & 16,76 \\
\hline $58^{\mathrm{a}}$ & $18 / 4 / 2001$ & & $19 / 04 / 2001-23 / 05 / 2001$ & 16,25 & & 1,5 & 16,3 \\
\hline $57^{\mathrm{a}}$ & $21 / 3 / 2001$ & & $22 / 03 / 2001-18 / 04 / 2001$ & 15,75 & & 1,1 & 15,84 \\
\hline $56^{a}$ & $14 / 2 / 2001$ & & $15 / 02 / 2001-21 / 03 / 2001$ & 15,25 & & 1,3 & 15,2 \\
\hline $55^{\mathrm{a}}$ & $17 / 1 / 2001$ & & $18 / 01 / 2001-14 / 02 / 2001$ & 15,25 & & 1,1 & 15,19 \\
\hline $54^{\mathrm{a}}$ & $20 / 12 / 2000$ & & $21 / 12 / 2000-17 / 01 / 2001$ & 15,75 & & 1,1 & 15,76 \\
\hline $53^{a}$ & $22 / 11 / 2000$ & & $23 / 11 / 2000-20 / 12 / 2000$ & 16,5 & & 1,2 & 16,38 \\
\hline $52^{\mathrm{a}}$ & $18 / 10 / 2000$ & & $19 / 10 / 2000-22 / 11 / 2000$ & 16,5 & & 1,4 & 16,56 \\
\hline $51^{\mathrm{a}}$ & $20 / 9 / 2000$ & & $21 / 09 / 2000-18 / 10 / 2000$ & 16,5 & & 1,2 & 16,6 \\
\hline $50^{\mathrm{a}}$ & $23 / 8 / 2000$ & & $24 / 08 / 2000-20 / 09 / 2000$ & 16,5 & & 1,2 & 16,54 \\
\hline $49^{a}$ & $19 / 7 / 2000$ & & $20 / 07 / 2000-23 / 08 / 2000$ & 16,5 & & 1,5 & 16,51 \\
\hline $48^{\mathrm{a}}$ & & uso/baixa & $10 / 07 / 2000-19 / 07 / 2000$ & 17 & & 0,5 & 16,96 \\
\hline & $20 / 6 / 2000$ & $\underline{\text { baixa }}$ & $21 / 06 / 2000-07 / 07 / 2000$ & 17,5 & & 0,8 & 17,34 \\
\hline $47^{\mathrm{a}}$ & $24 / 5 / 2000$ & & $25 / 05 / 2000-20 / 06 / 2000$ & 18,5 & & 1,3 & 18,39 \\
\hline $46^{\mathrm{a}}$ & $19 / 4 / 2000$ & & $20 / 04 / 2000-24 / 05 / 2000$ & 18,5 & & 1,6 & 18,55 \\
\hline $45^{\mathrm{a}}$ & & uso/baixa & $29 / 03 / 2000-19 / 04 / 2000$ & 18,5 & & 1,1 & 18,6 \\
\hline & $22 / 3 / 2000$ & baixa & $23 / 03 / 2000-28 / 03 / 2000$ & 19 & & 0,3 & 18,94 \\
\hline $44^{\mathrm{a}}$ & $16 / 2 / 2000$ & & $17 / 02 / 2000-22 / 03 / 2000$ & 19 & & 1,6 & 18,88 \\
\hline $43^{\mathrm{a}}$ & $19 / 1 / 2000$ & & $20 / 01 / 2000-16 / 02 / 2000$ & 19 & & 1,5 & 18,87 \\
\hline $42^{\mathrm{a}}$ & $15 / 12 / 1999$ & & $16 / 12 / 1999-19 / 01 / 2000$ & 19 & & 1,7 & 19 \\
\hline
\end{tabular}




\section{Especificações do Contrato de Opção deCompra sobre Taxa de Câmbio de Reais por Dólar Comercial}

1. Definições

Contrato (especificações): termos e regras sob os quais as operações serão realizadas e liquidadas.

Contrato negociado: um lote (unidade de negociação) negociado sob os termos e as regras destas especificações. Série: conjunto de características do contrato de opção, que determinam a data de vencimento e seu preço de exercício, sendo identificada por código específico estabelecido pela BM\&F.

Compra de um contrato: operação na qual o participante é titular, ou seja, tem o direito de comprar o objeto de negociação pelo preço de exercício.

Venda de um contrato: operação na qual o participante é lançador, ou seja, se exercido pelo titular tem a obrigação de vender o objeto de negociação pelo preço de exercício.

2. Objeto da opção

A taxa de câmbio de reais por dólar dos Estados Unidos da América, para entrega pronta, contratada nos termos da Resolução 1690/1990, do Conselho Monetário Nacional (CMN).

3. Cotação

Prêmio da opção, em reais por US\$1.000,00, com até três casas decimais.

4. Variação mínima de apregoação R \$0,001 por US\$1.000,00.

5. Oscilação máxima diária

Não há limites de oscilação diária, podendo a Bolsa, excepcionalmente e a seu critério, estabelecê-los.

6. Unidade de negociação

Cada opção refere-se a um lote padrão de US\$50.000,00.

7. Preços de exercício Os preços de exercício serão estabelecidos e divulgados pela BM\&F, expressos em reais por US\$1.000,00.

8. Meses de vencimento

Todos os meses.

9. Número de vencimentos em aberto

Conforme autorização da BM\&F.

10. Último dia de negociação

Último dia útil (dia de pregão) do mês anterior ao mês de vencimento do contrato.

11. Data de vencimento

Primeiro dia útil (dia de pregão) do mês de vencimento do contrato.

12. Day trade

São admitidas operações day trade (compra e venda, no mesmo dia de pregão, da mesma quantidade de contratos da mesma série), que se liquidarão automaticamente, desde que realizadas em nome do mesmo cliente, por intermédio da mesma Corretora associada sob a responsabilidade do mesmo Membro de Compensação ou realizadas pelo mesmo Operador Especial sob a responsabilidade do mesmo Membro de Compensação. A liquidação financeira dessas operações será realizada no dia útil subseqüente, sendo os valores apurados de acordo com o item 13.

13. Movimentação financeira do prêmio

Pagamentos e recebimentos de prêmios serão efetuados no dia útil seguinte ao de realização da operação.

O valor de liquidação do prêmio por contrato será calculado de acordo com a seguinte fórmula:

$$
\mathrm{VLP}=\mathrm{P} \times \mathrm{M}
$$

VLP = valor de liquidação do prêmio por contrato;

$\mathrm{P}=$ prêmio da opção;

$\mathrm{M}=$ multiplicador do contrato, estabelecido em 50.

14. Exercício

A opção é do tipo europeu e será exercida automaticamente, na data de vencimento do contrato, sempre que o valor de liquidação no exercício, conforme definido no item 15, for positivo e não houver solicitação de nãoexercício pelo titular (bloqueio de exercício).

15. Condições de liquidação no exercício

A liquidação das posições exercidas será realizada de forma exclusivamente financeira, mediante o crédito do valor de liquidação ao titular e o débito do mesmo valor ao lançador. 
O exercício será processado pela Bolsa na data de vencimento e o valor de liquidação por contrato será calculado de acordo com a seguinte fórmula:

$$
\mathrm{VL}=[(\mathrm{TC} \times 1.000)-\mathrm{PE}] \times \mathrm{M}
$$

$\mathrm{VL}=$ valor de liquidação do exercício por contrato;

$\mathrm{TC}$ = taxa de câmbio de reais por dólar dos Estados Unidos da América, para entrega pronta, contratada nos termos da Resolução 1690/1990, do CMN, definida como a taxa média de venda apurada pelo Banco Central do Brasil (Bacen), segundo critérios por ele definidos, e divulgada por meio do Sisbacen, transação PTAX800, opção " 5 " (cotação de fechamento), sendo utilizada com até quatro casas decimais. A taxa de câmbio utilizada será aquela verificada no último dia do mês imediatamente anterior ao mês de vencimento do contrato, independentemente de, nesse dia, haver ou não pregão na BM\&F;

$\mathrm{PE}=$ preço de exercício;

$\mathrm{M}=$ conforme definido no item 13 .

Os resultados financeiros do exercício serão movimentados no dia útil subseqüente à data de vencimento.

\section{- Condições especiais}

Se, por qualquer motivo, o Bacen não divulgar a taxa de câmbio correspondente ao último dia do mês imediatamente anterior ao mês de vencimento deste contrato, a BM\&F poderá, a seu critério:

a) prorrogar a liquidação do contrato até a divulgação oficial; ou

b) utilizar como valor de liquidação o prêmio médio do último dia de negociação ou um valor por ela arbitrado.

Em ambos os casos, a BM\&F poderá corrigir o valor de liquidação por um custo de oportunidade por ela arbitrado, desde o dia subseqüente à data de vencimento até o dia de sua efetiva liquidação financeira.

Ainda, se o Bacen suspender a divulgação diária da taxa de câmbio objeto deste contrato ou em caso de força maior, que comprometa o livre funcionamento do mercado físico, a BM\&F encerrará a negociação deste contrato, liquidando as posições em aberto pelo prêmio médio do último pregão ou por um valor por ela arbitrado, a seu critério.

A BM\&F poderá ainda, em qualquer caso, arbitrar um preço para a liquidação deste contrato se, a seu critério, julgar não serem representativos tanto a cotação divulgada pelo Bacen quanto o prêmio médio do último pregão.

16. Margem de garantia para o lançador

Será exigida margem de garantia de todos os comitentes lançadores de opções com posição em aberto, cujo valor será atualizado diariamente pela Bolsa, de acordo com os critérios de apuração de margem estabelecidos pela BM\&F.

\section{Ativos aceitos como margem}

Dinheiro, ouro, cotas do Fundo dos Intermediários Financeiros (FIF) e, mediante autorização prévia da Bolsa, títulos públicos federais, títulos privados, cartas de fiança, ações e cotas de fundos fechados de investimento em ações.

\section{Registro primário de contratos}

A BM\&F poderá autorizar o registro especial de posições neste contrato, provenientes de leilões realizados pelo Banco Central do Brasil para séries específicas. As condições desse registro serão estabelecidas pela Bolsa por meio de Ofício Circular. As posições criadas sob tais condições poderão ser livremente negociadas, de acordo com estas especificações, a partir do dia autorizado pela BM\&F.

\section{Custos operacionais}

\section{- Taxa operacional básica}

Operação normal: $0,4 \%$; day trade: $0,2 \%$; exercício: $0,2 \%$.

Nas operações (normal e day trade), a taxa operacional básica é calculada sobre seu respectivo valor. No exercício, a incidência é sobre o valor de liquidação multiplicado pelo número de contratos.

Nos casos abaixo, a taxa operacional básica será de $0,1 \%$ em cada ponta, desde que as operações sejam realizadas no mesmo dia de pregão, em nome do mesmo cliente, intermediadas pela mesma Corretora associada e registradas pelo mesmo Membro de Compensação ou realizadas pelo mesmo Operador Especial e registradas pelo mesmo Membro de Compensação:

a) exercer uma opção de compra e ser exercido em outra opção de compra;

b) exercer uma opção de compra e exercer uma opção de venda;

c) ser exercido em uma opção de compra e ser exercido em uma opção de venda.

A taxa operacional básica está sujeita a valor mínimo estabelecido pela Bolsa.

- Taxa de liquidação

$0,2 \%$ sobre o valor do exercício. 
- Taxas da Bolsa (emolumentos e fundos)

$6,32 \%$ da taxa operacional básica.

- Taxa de registro

Valor fixo divulgado pela BM\&F.

Os custos operacionais são devidos no dia útil seguinte ao de realização da operação ou do exercício.

Os Sócios Efetivos pagarão no máximo 75\% da taxa operacional básica e 75\% dos demais custos operacionais (taxa de registro e da Bolsa).

Os investidores institucionais pagarão $75 \%$ das taxas de registro e da Bolsa.

20. Normas complementares

Fazem parte integrante deste contrato, no que couber, a legislação em vigor, as normas e os procedimentos da BM\&F, definidos em seus Estatutos Sociais, Regulamento de Operações e Ofícios Circulares, bem como as regras específicas das autoridades governamentais que possam afetar os termos aqui contidos.

Na hipótese de situações não previstas neste contrato, bem como de medidas governamentais ou de qualquer outro fato que impactem a formação, a maneira de apuração ou a divulgação de sua variável, ou que impliquem, inclusive, sua descontinuidade, a BM\&F tomará as medidas que julgar necessárias, a seu critério, visando a liquidação do contrato ou sua continuidade em bases equivalentes.

ÚLTIMA ATUALIZAÇÃO: OFÍCIO CIRCULAR 022/2003-DG, DE 05/03/2003 